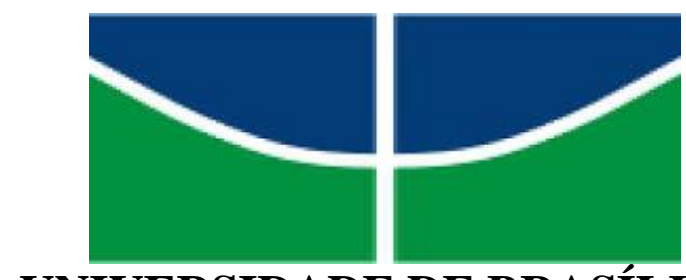

UNIVERSIDADE DE BRASÍLIA

FACULDADE DE DIREITO

PROGRAMA DE PÓS-GRADUAÇÃO EM DIREITO

MESTRADO EM DIREITO, ESTADO E CONSTITUIÇÃO

ASPECTOS DE UMA TRANSIÇÃO: A RECONSTRUÇÃO DO DIREITO CIVIL PARA UM DIREITO CIVIL-CONSTITUCIONAL À LUZ DA TEORIA DOS SISTEMAS, DA TÓPICA E DA DIGNIDADE DA PESSOA HUMANA

Antonielle Julio

Brasília/DF

Março de 2016 


\section{ASPECTOS DE UMA TRANSIÇÃO: A RECONSTRUÇÃO DO DIREITO CIVIL PARA UM DIREITO CIVIL-CONSTITUCIONAL À LUZ DA TEORIA DOS SISTEMAS, DA TÓPICA E DA DIGNIDADE DA PESSOA HUMANA}

Dissertação de Mestrado apresentada ao Programa de Pós-Graduação stricto sensu em Direito da faculdade de Direito da Universidade de Brasília (UNB), como requisito à obtenção do título de Mestre em Direito.

Orientador: Professor Doutor Ricardo Vieira de Carvalho Fernandes 


\section{UNIVERSIDADE DE BRASÍLIA \\ FACULDADE DE DIREITO \\ PROGRAMA DE PÓS-GRADUAÇÃO EM DIREITO \\ MESTRADO EM DIREITO, ESTADO E CONSTITUIÇÃO}

Termo de Aprovação

A presente dissertação intitulada "Aspectos de uma transição: a reconstrução do Direito Civil para um Direito Civil-Constitucional à luz da teoria dos sistemas, da tópica e da Dignidade da Pessoa Humana", da autoria de Antonielle Julio, defendida perante a banca examinadora em 31 de março de 2016, foi julgada e aprovada como adequada para a obtenção do título de Mestre em Direito.

\section{BANCA EXAMINADORA:}

Professor Doutor RICARDO VIEIRA DE CARVALHO FERNANDES

Orientador- Universidade de Brasília (FD)

Professor Doutor MENELICK DE CARVALHO NETTO

Membro- Universidade de Brasília (FD)

Professora Doutora INEZ LOPES

Membro- Universidade de Brasília (FD)

Professor Doutor MARLON TOMAZETTE

Membro- UNICEUB 


\section{DEDICATÓRIA}

Dedico este singelo trabalho a Deus, meu Senhor, que por sua Graça e amor infinito, concedeu-me saúde, força, um átimo de inteligência e alguma sabedoria, para com esforço e dedicação superar as barreiras que se colocaram diante de mim. Não conseguiria sem sua unção.

Dedico ainda, a Antônio Eustáquio Julio e Élida Mendonça Julio, meus amados pais que me ensinaram o valor da honra, da honestidade e da verdade, para trilhar amparado o caminho da vida. Sem eles eu não seria mais do pouco que sou.

A Daniela Clemente minha esposa, exemplo de uma mulher humilde, lutadora, e ao mesmo tempo tão doce que defronte as adversidades, se manteve sempre firme para cuidar de nosso lar, mesmo diante de minha indesculpável ausência. 
Quero muito agradecer àqueles que se fizeram em luzes para ajudar este errante a encontrar um caminho seguro. A todos os professores que pacientemente se inclinaram para ouvirem minha voz. Em especial ao Professor Henrique Araújo Costa, pela humildade, simplicidade, paciência e dedicação a este discípulo; Ao Professor Menelick de Carvalho Netto, pela inesquecível lição de amor e dedicação à ciência jurídica e por não ter poupado esforços para me tornar um estudante melhor; Ao Professor Marcelo Neves, por sua paciência em ensinar a este pobre as primeiras linhas de um novo patamar dos estudos jurídicos; Ao Professor Miroslav Milovic que do alto de sua genial simplicidade não mediu tempo para discutir comigo, temas de alta indagação; À Professora Inez Lopes, por sua doação plena em prol do conhecimento passado aos alunos e especial a este aluno; Ao Professor Ricardo Vieira de Carvalho Fernandes, que demonstrando um senso de grandeza, humanidade e amor à cátedra, veio sem medidas em meu socorro em momento que mais precisei. Sem dúvida, cada um se tornou, à sua maneira, exemplo de crescimento para mim. 


\section{RESUMO}

O presente trabalho analisa aspectos do processo de transição do Direito Civil para um Direito Civil-Constitucional à luz da teoria sistêmica, da tópica e utilizando eixo fundamental o princípio da Dignidade da Pessoa Humana.

Esse fenômeno é reconhecido em face do Direito Civil, pelas profundas modificações que o Direito em si vem sofrendo principalmente nos dias atuais, com a sedimentação do pensamento constitucional, por via da teoria dos direitos fundamentais tendo como princípio fundante a Dignidade da Pessoa Humana.

O trabalho não trata de um resgate histórico linear desse processo transformador do Direito Civil, mas antes, busca esclarecer por via da teoria dos sistemas em Luhmann, como a comunicação entre sistemas autopoiéticos primeiro em nível transverso entre ordens jurídicas, e depois a nível interno entre os sistemas de Direito Constitucional e Direito Civil, acabou por provocar reestruturações deste último sistema.

Assim, a análise se pauta por uma demonstração de como Constituição e Direito Civil, interagem por via da comunicação para estabilizar expectativas congruentes que emanam do sistema constitucional como o sistema fundante e onde se encontra a norma fundamental. Não se tratam de simples processos hermenêuticos, mas antes, um processo mais profundo de reconstrução normativa do Direito Civil.

Como não poderia deixar de ser, ao se considerar a pessoa humana como a destinatária e resultante dessas transformações, principalmente em face da norma civil, o estudo atravessa os campos conceituais do sujeito de direitos como resultado de uma diferenciação funcional do sistema social, num cenário de hipercomplexidade em que valores comuns são convergidos dentro do sistema social como um todo, que também por 
via de comunicação sistêmica não só com sistemas como política e economia, mas também com o sistema jurídico, acaba por provocar evolução neste último, principalmente pela evolução do sistema constitucional.

Assim, ao se falar num princípio da Dignidade da Pessoa Humana como eixo fundante dos processos de transição do Direito Civil, se está admitindo essa profunda transformação do próprio sistema social e sua influência nos demais sistemas. Trazer o sujeito de direitos de uma ideia abstrata, um modelo jurídico, para a realidade concreta é tarefa que se impõe porque a implementação de todo o conjunto normativo civil, a partir de suas transformações se baseia na observância do respeito aos direitos e princípios protetivos desta pessoa.

Desta feita pode se falar que o Direito Civil na modernidade é um conjunto de normas constitucionalizadas, prospectivas e substanciais que visa atuar para implementação de toda uma série de preceitos voltados à pessoa humana.

Por fim, a tópica aparece como modelo de racionalidade do pensamento com abertura para a reflexão, voltada para a resolução de problemas em concreto, influenciando principalmente a jurisprudência. E essa abertura concede à tópica coexistência com o pensamento sistêmico, já que, compreende a incompletude dos sistemas e sua constante operação de fechamento e abertura na comunicação, o que sem dúvida compele a reflexão sobre os modelos de topoi propostos a fim de readequá-los segundo os critérios evolutivos do sistema jurídico.

Palavras-chave: racionalidade - tópica- sistemas autopoiéticos- processos comunicacionais- pessoa- sujeito de direitos- dignidade da pessoa humana- sistema constitucional- sistema civil- função social- boa-fé. 


\begin{abstract}
The present research examines the process aspect of transition from civil-law to a Constitutional-Civil Law throw the systemic theory, topical and using mainly the principle of Human Dignity.

This phenomenon is recognized by Civil Law by profounds changes that the law has been suffering mostly nowadays, with the constitutional law thoughts sedimentations by the theory of fundamental rights having as the founding principle of the Human Dignity.

This research is not about a linear historic rescue of this Civil Law transformative process, but clarify throw the theory of systems, written by Luhmann, like the communication between the systems autopoietic first in transverse level between legal systems and then internally between the constitutional and civil law systems, that caused the restructuring of this last system.

So, the review is based on a demonstration of how Constitution and Civil Law interact by the communications to stabilize congruent expectations from the constitutional system as the founding system where the basic rule is. It is not about simple hermeneutic process, but a deeper process of normative reconstruction of civil law.

As it couldn't let to be, considering the human people as the addressed and result of this changes, especially in view of Civil Law, the study runs through the conceptual field of subjects of law as the result of a differential function from the social system, in a hyper complexity scenario that usual values are converged inside of the social system that also by the systemic communication not only with systems such as politics and economics, but also with the legal system, that eventually cause evolution in the latter, mainly for the evolution of constitutional system.

Then, speaking about the principle of human dignity as the founding process of the Civil Law transitions, it admits that this deeply transformation of the social system itself and its influence on the other systems. Bring the subject of rights from an abstract idea, a legal model, to reality is necessary because the implementation of entire set of civil rules from their transformation is based on observance of respect for the rights and protective principles of this person.

Soon, the civil law nowadays is a constitutionalized set of rules, forwardlooking and substantial which aims to act to implement a whole series of provisions geared to the human person.

Lastly, the topical appears as a model of rationality of thought with opening for reflection focused on solving problems in concrete, mainly influencing the jurisprudence. And this openness grants to topical coexistence with systems thinking, since it comprises the incompleteness of systems and its constant closing and openness operation in communication, which undoubtedly compels reflection on the topoi models proposed to readjust according to evolutionary criteria of the legal system.
\end{abstract}

Key Words: Rationality - Topical - Autopoetic Systems - Communication Processes - People - Subject of Rights - Dignity of Human Person - Constitutional System - Civil System - Social Role - Good Faith. 


\section{Riassunto}

Questo documento analizza gli aspetti del processo di transizione diritto civile per un diritto civile e costituzionale alla luce della teoria dei sistemi, attualità e utilizzando fondamentale asse il principio della dignità umana.

Questo fenomeno è riconosciuto a fronte del diritto civile, i profondi cambiamenti che la legge stessa viene principalmente soffrono oggi, con la sedimentazione del pensiero costituzionale, attraverso la teoria dei diritti fondamentali che hanno come fondatore principio della dignità umana .

Il lavoro non si occupa di una revisione storica lineare di questo processo di trasformazione del diritto civile, ma piuttosto intende chiarire per mezzo di teoria dei sistemi di Luhmann, come la comunicazione tra i primi sistemi autopoietici a livello trasversale tra i sistemi giuridici, e poi internamente tra i sistemi di Diritto costituzionale e Diritto civil, alla fine portano alla ristrutturazione di quest'ultimo sistema.

Pertanto, l'analisi è guidata da una dimostrazione di come la Legge Costituzione e civile, interagire attraverso la comunicazione via congruente a stabilizzare le aspettative provenienti dal sistema costituzionale come sistema fondamentale e dove la regola fondamentale è trovato. Questi non sono semplice processo ermeneutico, ma piuttosto un processo più profondo di ricostruzione normativa del diritto civile.

Come potrebbe essere, se si considera la persona umana come destinatario e risultato di queste modifiche, soprattutto a fronte della norma civile, lo studio attraverso i campi concettuali di diritti soggetti a causa della differenziazione funzionale del sistema sociale, uno scenario di hypercomplexity dove i valori comuni sono confluiti all'interno del sistema sociale nel suo complesso, che ha anche canale di comunicazione sistemica non solo con sistemi come la politica e l'economia, ma anche con il sistema giuridico, in ultima analisi, causando l'evoluzione in quest'ultimo principalmente dall'evoluzione del sistema costituzionale.

Così, quando si parla sul principio della dignità umana come asse fondamentale dei processi di transizione diritto civile, uno è ammettere questa profonda trasformazione del sistema sociale stesso e la sua influenza su altri sistemi. Portare il tema dei diritti di un'idea astratta, un modello giuridico per la realtà concreta è un compito che è necessario per l'attuazione di tutte le serie civili di regole, dalla sua trasformazione si basa sul rispetto per quanto riguarda i diritti di protezione ei principi della presente persona.

Questa volta si può dire che la legge civile nella modernità è un insieme di costituzionalizzato, lungimiranti e sostanziali regole che mira ad agire per attuare una serie di disposizioni volte a persona umana.

Parole chiave: razionalità - topica sistemi autopoiéticos- processi comunicacionaissoggetto personalità della dignità sui diritti della persona umana - sistema costituzionalmente funzione civile - sistema socialmente buona fede. 


\section{SUMÁRIO}

INTRODUÇÃO 11

1 POR UM MODELO DE RACIONALIDADE DEMONSTRATIVO DO FENÔMENO DE TRANSIÇÃO DO DIREITO CIVIL E SUA CONTEXTUALIZAÇÃO NA SOCIEDADE COMPLEXA

1.1 Considerações iniciais de um modelo analítico a partir da análise da conjunção da tópica e da sistemática na esfera do Direito Civil

1.2 A concepção de sistemas em Luhmann como modelo demonstrativo do processo evolutivo do Direito e da sociedade.

1.3 Direito Civil na policontexturalidade e diferenciação funcional de sistemas: da problemática da dicotomia público e privado ao momento atual .................................... 49

2 A REALIZAÇÃO DE UM DIREITO CIVIL CONSTITUCIONAL A PARTIR DA DIMENSÃO DO "SER HUMANO"

2.1 Pela construção de um sujeito de direitos a partir da conceituação desde a pessoa humana e sua posição enquanto sujeito de direitos.

2.2- A importância da Dignidade da pessoa Humana como eixo fundamental para a (re) construção do Direito Civil

2.2.1 Síntese da construção de uma ideia de Dignidade a partir de uma visão europeia .. 83

2.2.2 A influência da teoria dos Direitos Fundamentais como concretude de um princípio da dignidade no contexto latino americano e o Brasil. Um breve olhar do prisma constitucional

2.2.3 Objeto, valoração da dignidade da pessoa humana como resultado da

hipercomplexidade social. Breve visão Luhmaniana sobre o Estado do bem-estar

2.2.4 Liberdade e direitos fundamentais como pressupostos da dignidade da pessoa humana em face do sujeito de direitos.

3 POR UM DIREITO CIVIL CONSTITUCIONAL NA ÉGIDE DA PESSOA HUMANA

3.1 Por um Direito Civil-Constitucional: A função social da propriedade e seu incremento no sistema jurídico brasileiro

3.2 Por um Direito Civil-Constitucional: A função social dos contratos e uma breve análise da teoria contratual

3.3 Por um Direito Civil-Constitucional: A boa-fé objetiva em sua dimensão de eticidade pautada com o princípio da dignidade da pessoa humana.

CONCLUSÃO

REFERÊNCIAS 163 


\section{INTRODUÇÃO}

Vivemos em uma sociedade plural, em franco processo de diferenciação, constante evolução e que tem demandado profundas e contínuas modificações no ordenamento jurídico como um todo. Tratam-se de consequências de uma construção que há muitos séculos vem se sedimentando no seio da sociedade mundial, idealizada pelas concepções humanitárias, solidárias e éticas que permeiam o consciente coletivo.

Por mais que hajam interferências da política, da economia o fato é que a sociedade em extrato mundial converge valores, princípios protetivos e exige uma maior gama de normas capazes de garantir o implemento da justiça, da equidade e do equilíbrio nas relações cada vez mais complexas na atualidade.

Este pensamento funda-se, por via de um constitucionalismo operacionalizado entre nós por um Direito Constitucional, que tem carreado essas mudanças a partir de uma acepção prospectiva da Constituição a qual supera sua condição lógico-formal, para dar azo a uma condição dinâmica que busca acompanhar, internalizar e implementar as mudanças decorrentes principalmente, mas não somente, da sociedade como destinatária final dos preceitos elencados no seio da norma fundamental.

Em plano interno, o Direito tem buscado evoluir em mesma sintonia com as mudanças ocorridas em plano externo, e a Constituição serve como esse filtro para a recepção de novos elementos e perspectivas que comutadas em normas constitucionais irradiam-se em todo o ordenamento.

O Direito Civil como parte deste ordenamento, recepciona tais transformações de modo a dar novos sentidos e finalidades a seus antigos princípios e dogmas, convertendo-se em um Direito Civil-Constitucional, o que nos levou ao problema desta pesquisa. 
Como se dá essa transformação no Direito Civil em um pretenso Direito Civil Constitucional? Como se operam essas transições?

A doutrina civilista, em geral, tem buscado com preocupação identificar nesta plêiade de fenômenos transformativos como o Direito Civil tem se condicionado a uma sincronização normativa, e isso é sem dúvida o cerne das questões levantadas acima.

Tomando por base que a temática desse trabalho perpassa tanto por uma análise do Direito Civil na modernidade, quanto pela contextualização do pensamento constitucional, então, justifica-se buscar algumas respostas ou ao menos salientar os pontos que mais importam, para deslindar um caminho inicial para evolução da pesquisa neste campo.

Sob este viés, este trabalho se propõe ao objetivo geral de tentar explicar como está se dando essa transição do Direito Civil, buscando identificar como se formam essas pontes de transição entre o Direito Constitucional e o Civil, assim como, determinar liames causais que se não explicarem por completo, ao menos indiquem os fenômenos para que se abram horizontes que tornem plausíveis futuras discussões.

E para tanto, a fim de delimitar a discussão e determinar os objetivos específicos da pesquisa, proporemos uma análise que busque demonstrar que esses processos de transição, não se dão simplesmente por um panorama histórico-evolutivo do Direito Civil, e tão pouco se tratam de transformações puramente hermenêuticas ou baseadas em mera subsunção a partir da norma constitucional em relação hierárquica com o ordenamento infraconstitucional.

Admitindo que a dignidade da pessoa humana como um dos fundamentos da República, converte-se de valor para um princípio de ordem objetiva no ordenamento, optamos por construir o pensamento a partir de um arquétipo de pensamento que 
demonstre como as transformações ocorrem em planos sistêmicos diferenciados, porém, não desconectados.

Transformações essas que atingem o Direito Civil, tendo por pináculo ou paradigma o princípio citado acima, ao ponto de falarmos numa reconstrução da norma civil e não apenas de uma releitura, como querem alguns pensadores em matéria civil.

E a arquitetura jurídica que se pretende neste trabalho desenha-se a partir da teoria dos sistemas de Luhmann, que por uma opção, nos pareceu mais adequada para esquadrinhar o fenômeno num plano abstrato, superior, porém, tangível e resolúvel no plano concreto.

Isto porque o pensamento delineado neste trabalho buscará demonstrar como essas transformações ocorrem em plano heterárquico, entre sistemas constitucionais transversos e entre comunicações internas entre os sistemas Constitucional e Civil. Mas, cabe esclarecer que buscaremos apenas citar a ocorrência do fenômeno para salientar o substrato onde ocorrem as transformações do sistema constitucional a partir de experiências, saberes e preceitos trocados entre ordens jurídicas diversas e como essas transformações afetarão o sistema interno civil. Em seu cerne, o trabalho se voltará especificamente para as transformações em plano interno.

No plano concreto o desafio será o de implementação destes preceitos transformadores que coligam Direito Constitucional e Civil. Consoante a isto, optamos por tentar explicar essa concretização a partir da tópica como método de racionalização do pensamento direcionado à solução de problemas concretos, sem preocupar-se em dar soluções estanques e exauríveis, justamente, porque ao se coadunar com as transformações sistêmicas autopoiéticas e constantes, pode a todo instante conclamar a reflexão de pensamentos, diretrizes e abrir novamente os horizontes para novas soluções diante da realidade que se apresente. 
Assim no delineamento deste projeto, a tendência é que o desenho das estruturas deste arquétipo de pensamento, conduza a um entendimento inicial de que por via de processos comunicacionais em nível transverso mundial, o sistema constitucional sofre as constantes irritações em seu ambiente por outros sistemas constitucionais que por suas vezes sofrem irritações do sistema social mundial, o que leva a um contingenciamento de expectativas desviantes que vão sendo recepcionadas e albergadas ou não como congruentes, assim como, interpretadas segundo o pensamento interno em cada contexto. No, entanto, com valores e princípios colmatados no consciente coletivo mundial, como é o caso da dignidade da pessoa humana.

Depois já em nível comunicacional interno, e aí reside a temática, buscaremos demonstrar como essas transformações alcançam a norma civil e a reconstroem, transformando-a em norma substantiva e prospectiva, daí porque faremos críticas ao modelo codificado e buscaremos dar um sentido evolutivo ao entendimento do Direito Civil.

Todavia, o questionamento sobre onde estará o sujeito neste processo transformador não ficará ao desabrigo de uma tentativa de resposta. Por isso mesmo a opção pela teoria alemã. Ao trabalhar com as transformações sistêmicas, eliminando de início o elemento subjetivo (um sistema social), simplesmente o guindaremos a um patamar de ações separado. Dessa forma, o trabalho dedicará parte significativa de seu corpo para explicar a construção do sujeito de direitos e sua colocação enquanto destinatário dos resultados dessa comunicação, assim como, ator protagonista das transformações dos sistemas por via de um sistema social evolutivo, diferenciado e inserido numa policontexturalidade.

A hipótese, portanto, deste trabalho, é que a transição do Direito Civil para um Direito Civil-Constitucional, se dá a partir de sua reconstrução realizada por via de 
processos de comunicação com o sistema constitucional e o sistema social, sendo que o resultado dessa reconstrução não será meramente hermenêutico, mas sim, estrutural, dinâmico, prospectivo e substancial. O princípio da Dignidade da Pessoa Humana, será a base fundante da argumentação, já que, em matéria civil, com certeza, o ser é o centro das relações jurídicas interpessoais e de direitos reais. A tópica será o modelo racional de implementação dessas transformações do Direito Civil no caso concreto.

A pretensão é de que o trabalho tenha três capítulos, sobre os quais buscaremos explicar toda a temática.

No primeiro capítulo, escorados principalmente nos pensamentos de Fachin, Cláudia Roesler e seu pensamento sobre Theodor Viehweg e sua tópica, além de Luhmann, Marcelo Neves e sua construção do pensamento luhmaniano e Teubner com seu pensamento sobre o sistema privado, buscaremos demonstrar a escolha de um modelo de racionalidade baseado na tópica e na teoria dos sistemas. E o mais importante será demonstrar que os dois modelos escolhidos poderão coabitar numa mesma linha de pensamento.

Neste mesmo capítulo, buscaremos contextualizar o Direito Civil, mostrando justamente sua colocação num contexto complexo de uma sociedade complexa, e como se dará sua transformação em face de processos comunicacionais. Para tanto, vamos tratar da discussão existente na summa divisio entre Público e Privado e vozes como a de Menelick Carvalho Netto, serão importantíssimas nessa abordagem de que o público não é mais um aparato de normas meramente estatais, enquanto que o privado não se atém mais a um egoísmo anterior à vida em sociedade.

No segundo capítulo o trabalho buscará dedicar esforços para a dimensão do ser, sua acepção enquanto sujeito de direitos e a importância desta construção para um Direito Civil que se pretende enquanto norma constitucionalizada. Nesta abordagem, a 
preocupação se dará com a realização do conceito de um sujeito de direitos, mas principalmente a construção do princípio da dignidade da pessoa humana, momento em que faremos inserção breve, mas necessária, na temática dos direitos fundamentais como concretizadores do metaprincípio da dignidade. Para tanto, usaremos principalmente Hanna Arendt e sua visão da condição humana, além da construção da consciência em Hegel e posições adotadas por códigos estrangeiros como alemão, francês e italiano, valendo lembrar aqui, que na conceituação de um sujeito de direitos não abstrato, pretendemos nos escorar na visão da escola italiana na voz de Rodotà e seu pensamento para a construção de um sujeito baseado numa realidade em constante mudança.

Como síntese da construção histórica do princípio na América Latina e no Brasil, faremos breve resgate seguindo o pensamento de doutrinadores como Cristiano Paixão e sua arqueologia do Direito Constitucional na América do Sul.

No terceiro e derradeiro capítulo, buscaremos demonstrar a problemática e reafirmar a hipótese deste trabalho, convergindo as ideias então propostas para mostrar como o Direito Civil vem se reconstruindo em um processo que ainda está ocorrendo.

Para tanto, vamos voltar os esforços para ilustrar essas transformações a partir do pensamento constitucional, com análises a respeito de institutos como a função social da propriedade e dos contratos, assim como, a boa-fé objetiva, desnudando a forma como estes princípios afetaram dogmas vetustos do Direito Civil e o compeliram a mudanças significativas em seu contexto normativo-positivo, e mais ainda, em seu aspecto substancial. Claro que, estes serão apenas alguns exemplos dos vários, como a recente lei de inclusão da pessoa com deficiência, ou as mudanças no direito de família.

Mas dada a apertada síntese do trabalho vamos nos ater a elementos transformativos intimamente ligados ao sistema constitucional e que voltam seu pensamento em prol da realização da dignidade da pessoa humana em relações jurídicas 
obrigacionais e de propriedade, até porque, uma incursão no direito de família, implicaria numa ampla pesquisa que destoaria do objeto proposto.

Para realizar a tarefa, além de autores já citados, lançaremos mão da análise de regras contidas no Código Civil Brasileiro, abrangendo seus fins e sua coligação com o sistema constitucional, sem olvidar suas raízes, mormente, no Direito Romano momento em que serão importantes as considerações de Santos Justo, lusitano e um dos grandes historiadores do Direito Europeu. E em cada abordagem principiológica que se fizer, buscaremos demonstrar como a tópica atua na concretização dessas reestruturações do Direito Civil, inclusive, com a citação de precedentes de cortes superiores a título de demonstração prática da aplicação de topois a partir da dimensão aqui apresentada.

A metodologia adotada será a exploratória à guisa de pesquisas bibliográficas, em livros, periódicos, repositórios de jurisprudências de tribunais superiores e sítios eletrônicos. A metodologia de aplicação do discurso será o lógico-dedutivo, na convicção de que servirá para descrever a equação e as soluções propostas na temática e afirmadas na hipótese.

O trabalho não se propõe a ser uma tese, e muito menos exaurir a discussão. Pretende antes ser meramente um fomentador desta, a fim de levantar a problemática a respeito das pontes de transição do Direito Civil para um Direito Civil-Constitucional, sem o temor de ser um trabalho incompleto, mas plausível para futuras pesquisas. 


\section{POR UM MODELO DE RACIONALIDADE DEMONSTRATIVO DO FENÔMENO DE TRANSIÇÃO DO DIREITO CIVIL E CONTEXTUALIZAÇÃO NA SOCIEDADE COMPLEXA}

Inicialmente ao se falar em transições do Direito Civil, em concreto, importante esclarecer que não se trata de um resgate histórico-social a par do desenrolar de acontecimentos desencadeados em determinados espaços temporais.

Mesmo porque uma percepção desta natureza demandaria em paralelo uma análise talvez puramente histórica e antropológica dos temas levantados, que desvirtuaria este trabalho que é mero início de análise da própria evolução do Direito Civil à luz do Constitucionalismo. Mais precisamente de uma Constituição Substancial ${ }^{1}$ calcada em racionalidade prospectiva tendo como eixo valorativo a dignidade da pessoa humana e os princípios fundamentais que a cercam.

A análise que se propõe não encontra substrato na linearidade histórica que se pretende como um plano homogêneo de fatos e acontecimentos. E necessariamente dentre os vários impedimentos de uma análise deste porte, sem querer ser simplista, podese citar a princípio o próprio desprestígio do processo de codificação pelo qual passou o Direito Civil tanto em meados do século XIX- quanto no século que se findou- no que se pretende analisar ao curso deste trabalho.

A par destas ideias iniciais, admitindo como marca fundante do presente século o pluralismo jurídico e a complexidade da sociedade moderna, traçar qualquer análise mesmo perfunctória com base numa ótica meramente normativista mesmo que sob a visão, por exemplo kelseniana de um sistema hierarquizado, voltada para a não

\footnotetext{
${ }^{1}$ FACHIN, Luiz Edson. Direito Civil: sentidos, transformações e fim. Rio de Janeiro: Renovar, 2015, p. 31
} 
observação dos fenômenos que transformam o sistema social num sistema plúrimo seria o mesmo que destacar da análise do problema, o próprio problema.

Desta feita, o ponto de partida da construção proposta neste trabalho, iniciarse-á pela definição de um caminho a partir de um modelo de análise que para além de ser um objeto explicativo, objetivará não só dar sustentação ao pensamento racional desenvolvido, como também, trará aproximação maior deste horizonte de eventos que se demonstra na complexa conjuntura em que a sociedade se encontra.

Obviamente que qualquer escolha deste porte não será de forma alguma tida como a toda de um caminho por si só infalível e tão como único. Mas, a necessidade de fixação dos fenômenos que são na verdade tijolos desta construção das pontes de transição do moderno Direito Civil não podem ser mais vistos como se as pontes já estivessem prontas, e tão pouco como se a transição já houvesse ocorrido.

Trata-se de delicada conjuntura de fatores que por sua evolução em contexto complexo, policontextural por assim dizer, vão formando-se ao sabor de eventos dinâmicos e em alguns momentos de difícil compreensão. Mas, olhando em qualquer direção deste horizonte a necessidade de fixação de um caminho é inevitável.

\subsection{Considerações iniciais de um modelo analítico a partir da análise da conjunção da tópica e da sistemática na esfera do Direito Civil}

Parece adequado delinear a configuração de um Direito Civil- Constitucional voltada para um discurso a priori dialético, que busca não no consenso puro e simples ou na fusão entre o dogmático Direito civil e substancial Direito Constitucional o ponto de inicialização de sua construção, mas antes busca na via do dissenso, onde se dão as restabilizações congruentes dos processos de transições do Direito Civil, que dentro de 
deste plexo de sistemas $^{2}$, determinarão o processo de continuação da comunicação e evolução do sistema.

Daí que em especial no Direito Civil, a determinação de um método analítico se torna mais relevante porque a necessidade de soerguer a ciência da teoria à praxis neste estrito campo de análise da interligação do direito civil e constitucional, não pode malograr numa busca pela certeza científica.

Certeza esta deveras criticada na visão de Roesler $^{3}$ que demonstrando a obra de Viehweg ${ }^{4}$ reitera a ideia de certeza para a construção de uma praxis adequada como uma pressuposição mecanicista cujas consequências absolutistas acabam por excluir que os homens em sociedade se mostrem dispostos, a partir de meras intelecções, a submeterse a uma autoridade estatal. Esta certeza consumada, continuando o eixo de pensamento da insigne professora, situa essa pretensa certeza científica à margem de qualquer processo comunicacional.

E tal crítica é importante à medida da compreensão de que a transformação da teoria em praxis está fadada à busca de uma forma de inserir-se como parte da consciência e reflexão dos membros da sociedade de modo que o resultado prático das demonstrações científicas vai amalgamar-se objetivamente às necessidades atuais. Sob este prisma, a rigidez conceitual com a qual o Direito Civil convive, tanto por seus dogmas, como conceitos antiquíssimos baseados em grande parte na romanística, parece

\footnotetext{
${ }^{2}$ E aqui é importante destacar que não nos é desconhecido o conceito polissêmico de sistema, porém, elucidativo dizer que pelo sentido a ser dado no trabalho e o alcance que as transformações podem dar ao Direito Civil, por opção, vamos buscar demonstrar os processos de comunicação sistêmica a partir de noções breves da teoria de Luhmann em Marcelo Neves (c.f. NEVES, Marcelo. Entre Têmis e Leviatãa: uma relação difícil: o Estado Democrático de Direito a partir e além de Luhmann e Habermas. São Paulo: Editora WMF Martins Fontes, $3^{a}$ ed, 2012), sem olvidar a opção que nos foi dada na análise crítica dos sistemas de Kelsen a partir de Joseph Raz (c.f. HAZ, Joseph. O conceito de sistema Jurídico: uma introdução à teoria dos sistemas jurídicos. Trad. Maria Cecília Almeida. São Paulo: Editor WMF Martins Fontes, 2012), daí porque nossa preocupação em situar o leitor no contexto que pretendemos construir. Contudo, não se trata de um trabalho calcado puramente na teoria sistêmica alemã.

${ }^{3}$ ROESLER, Claudia Rosane. Theodor Viehweg e a ciência do Direito. Tópica, Discurso, Racionalidade. 2.ed. Belo Horizonte: Arraes Editores, 2013, p 20-21

${ }^{4}$ A obra em si foi traduzida para o português pelo Prof. Tércio Sampaio Ferraz Jr., em co-edição do Ministério da Justiça e UNB (1979). As citações deste trabalho se baseiam nas citações feitas por Roesler.
} 
começar a esvanecer diante de um quadro que na atualidade demonstra ávida velocidade de modificação de seu contexto à medida da própria evolução de uma sociedade policêntrica e multicultural.

Mas eis que surge a problemática de aplicação do método científico que demonstre esse fenômeno sem retroceder aos mesmos conflitos acima descritos. Viehweg ${ }^{5}$ encerra seu pensamento inicial no resgate da tópica como um método racional de pensar por problemas (Problemdenken), inserindo-a principalmente na jurisprudência que se lhe torna como ciência jurídica e levanta polêmica a respeito da relação com o pensamento sistemático (Systemdenken) que mesmo em sua obra não traz clareza sobre qual método seria mais adequado à análise da evolução da ciência do Direito talvez pela própria imprecisão dos conceitos apresentados. Mas, isto não vem ao caso no presente trabalho.

O mais importante é que Theodor ao dimensionar a jurisprudência como um procedimento especial de discussão de problemas enaltece a tópica como metodologia em contraposição a um sistema dedutivo, o que determina o centro da polêmica.

Mas de qualquer forma, ressalta a reação deste autor quanto a sistematização fechada do Direito enquanto ciência o que de fato impediria a própria realização dos escopos da ciência do Direito, pelo simples fato de que o seu mote estaria na busca da realização da justiça no caso concreto a partir da subsunção que em si seria determinada pela tópica.

Isto porque a ciência constantemente se depararia com aquilo que Viehweg apontou como aporia fundamental, que no entendimento de estudiosos seria a busca pela determinação do justo em cada caso concreto. Baseado na ideia de K. Lüderssen, citado

\footnotetext{
${ }^{5}$ Op. cit. p. 28
} 
por Garcia Amado "uma busca racionalizada de premissas” onde as tais, seriam obtidas objetivamente entre as mais adequadas à solução de um problema inafastável, tomando em consideração alguns pontos de vista (topoi) que para legitimarem-se enquanto procedimento racional de silogismos partem do debate, considerado por Viehweg como única instância controladora.

Nesta mesma linhagem de raciocínio, as premissas obtidas se legitimam pelo consenso entre os debatedores. Ou seja, se submetem a um critério de adequação. Somente à luz do próprio problema, com a exposição das premissas levantadas os topoi são avaliados como adequados ou inadequados.

Todavia, não apenas uma adequação das premissas deve ser levada em consideração na ideia de Viehweg, principalmente porque a construção das mesmas se justifica pela submissão do pensamento tópico ao problema. Evidentemente que, toda teoria que pretenda a praxis deve debruçar-se para solução de problemas no caso concreto.

Neste viés não é exagerado dizer que a tópica é essencialmente a formulação de um pensamento, talvez um arquétipo teórico e metodológico, em torno do caso- em direção do problema- o que não impede críticas pela restrição que pode trazer já que essa intensa vinculação com o problema não pode ser vista como a construção de um racionalismo estanque, cujas cadeias formadas a partir das premissas acabem por determinar conclusões que, embora corretas, tornem-se inadequadas a partir da própria evolução do problema, por exemplo, por nuances não observadas mas agora insurgentes comutando as conclusões apriorísticas em obsoletas, inábeis pela mutação sofrida pelo problema.

\footnotetext{
${ }^{6}$ K. Lüderssen, Dialektik, Topik und KonKretes Ordnungsdenken in der Jurisprudenz, in Festschrift für Richard Lange zum 70. Geburstag, de Gruyter, Berlim/Nova York 1976:1.019-1042, p 1.026, apud GARCIA, Juan Antonio Amado. Teorías de la tópica jurídica. Madri: Civitas, 1988 passim.
} 
De outro lado está a concepção de sistema jurídico que, repita-se, por seu sentido polissêmico, será analisado apenas por acepções que depreendam no curso da convergência com o fenômeno alardeado da concreção de um Direito CivilConstitucional, voltado o estudo apenas para tentar explicar a visão de sistema e sua conexão com a tópica, rumo a um modelo tópico - sistemático

Partindo da visão de Karl Larenz ${ }^{7}$ os sistemas podem ser determinados pela função ou "atinentes ao sentido", assim distinguidos dos sistemas formados por conceitos ou abstratos.

Estes são erigidos por propriedades particulares dos objetos apreendidos pela experiência, cuja essência determina a criação de um conceito a partir do qual podem ser elaborados novos conceitos tendo em vista sempre o grau de generalidade e abstração.

Esse tipo de construção resulta na formação de um sistema permeado por conceitos praticamente dogmáticos, extremamente genéricos, a partir dos quais todo o emaranhado conceitual que vai se formar no processo dinâmico de evolução do próprio sistema vigore sempre ancorado nos conceitos primários. Há um processo operativo praticamente cíclico entre os conceitos tidos como inferiores, àqueles mais superiores e genéricos. Sob este aspecto, trata-se de um sistema logicamente estruturado, sistematizado de forma a criar uma operação extremamente fechada.

Em contraposição a esta visão, os sistemas concretos hegelianos, ainda no pensamento de Larenz que os comparou, determinam-se pela totalidade dos conceitos “de valor" que os aproxima de uma concretude buscando sempre a submissão a valores subjacentes aos quais se deve recorrer para o fim de fixar a exata aplicação dos conceitos.

Essas considerações de um modo genérico denotam que um sistema jurídico, nesta visão, constitui-se enquanto um sistema de princípios gerais de Direito. Um sistema

\footnotetext{
${ }^{7}$ LARENZ, Karl. Metodologia da ciência do Direito. Fundação Calouste Gulbenkian, 2.ed, 1989, p.532.
} 
dotado de um conjunto normativo dotado de sentido construído a partir da interpretação sistemática não só dos textos normativos ${ }^{8}$ como de todo um conjunto de valores que atribuem nesta perspectiva, compreensão do significado como conteúdo conceitual do texto normativo, e dão ao intérprete a condição de construir e reconstruir o sentido da norma ou do sistema normativo. Tem-se desta forma uma adequação ou conexão de valores subjacentes a uma ordem principiológica interna o que de forma inconteste contrapõe-se à ideia de um sistema de conceitos gerais e abstratos.

A respeito destas adequações valorativas ${ }^{9}$ existe exigência ético-jurídica de atrelamento ao princípio da igualdade ${ }^{10}$ para compelir os poderes estatais, a vivenciar os valores cultivados no seio social adequando-os à realidade material o que em verdade evita as ambiguidades e discrepâncias que geram por sua vez contradições e insegurança jurídica.

Por ser um sistema axiológico, fundamental que seja norteado por princípios gerais de Direito que são em última análise a expressão máxima de valores fundamentais que existem para que deles se emane a ordem jurídica e mais ainda, porque os tais mantêm a unidade desta ordem jurídica.

Canaris ${ }^{11}$ explica, ainda no sentido empregado por Larenz, que a base de um sistema calcada em princípios e não em conceitos tem significação importante, porque à medida que existe um processo dinâmico de evolução valorativa e social, pode-se dizer que existe um portal aberto para ressignificação de valores já introduzidos que exteriorizarão conteúdo material próprio adequado à necessidade que se impõe. Portanto,

\footnotetext{
${ }^{8}$ AVILA, Humberto. Teoria dos Princípios: da definição à aplicação dos princípios jurídicos. São Paulo: MALHEIROS EDITORES LTDA, $11^{\mathrm{a}}$ ed, 2010, p. 30 e ss.

9 CANARIS, Claus Wilhelm. Pensamento sistemático e conceito de sistema na ciência do direito. Introdução e trad. De A. Menezes Cordeiro. Lisboa: Fundação Calouste Gulbenkian, 1996 passim.

${ }^{10}$ CANARIS, Idem, ibidem p 18 e ss., onde o autor ressalta a já conhecida máxima de "tratar o igual de modo igual e o diferente de forma diferente, de acordo com a medida da diferença".

${ }^{11}$ Idem, ibidem.
} 
não são estanques como os conceitos lógicos abstratos, que em si exigem ausência de contradição.

Outrossim, deve ficar clara a imprescindibilidade da formulação de conceitos mesmo num sistema axiológico, porque ao se considerar o sistema jurídico como um sistema que busca a subsunção, mesmo que pela aplicação de princípios e valores, a recorrência sempre em caso de dúvida aos conceitos gerais já estabelecidos ${ }^{12}$ é necessária.

Mas não há como negar em breve retorno histórico que a tendência à formação de um sistema de conceitos abstratos consoante uma ordem lógico-formal sempre foi a preferência no desenvolvimento do Direito, até porque as exigências de não contradição, exatidão cartesiana das proposições, completude e exaustão eram exigências para manutenção das bases da ciência jurídica. As codificações são o exemplo cabal desse período.

A legislação, a criação de códigos nacionais e consequentemente a idealização de sistemas jurídicos de Normas (norma fundante e justificação dinâmica) ${ }^{13}$ e sistemas jurídicos de Leis ${ }^{14}$ foram a tônica desde os vetustos idos do Iluminismo, com o escopo principal de colocar as concepções do direito nacional em prática.

Existem vários e vários exemplos marcantes desse período, dos quais destacamos sem maiores pretensões os reformadores com o Papa Gregório VII no século XI, que contavam com complexo sistema normativo romanístico, eclesiástico e

\footnotetext{
${ }^{12}$ CANARIS. Op.cit. p.84 e ss.

${ }^{13}$ E aqui Joseph Haz constrói sua idealização a partir de Kelsen, mormente quanto a natureza das normas enquanto reguladoras e justificadoras da conduta humana amparadas por razões convencionais de obediência, sob a forma da perspectiva de que alguma sanção decorra da desobediência. Mas em sua obra ele vai adiante buscando no autor alemão a distinção de sistema normativo e leis, para colocar a norma fundamental como instrumento de inter-relação sistemáticas entre as normas jurídicas. Sob este prisma a norma fundamental existe na consciência jurídica de uma simples análise dos enunciados jurídicos normativos, logo, a normal fundamental é pressuposta. (Haz, op.cit., p.161 e ss)

${ }^{14}$ Neste ponto Joseph traduz particular interpretação de Hart, para quem a normatividade do Direito significa que toda lei é norma, e passa a destrinchar o sistema jurídico a partir de leis que são normas e leis que não são normas, mas guardam relações internas com as normas jurídicas, ou seja, afetam a existência ou a aplicação das normas jurídicas por via de relações internas ao sistema jurídico. (Op.cit, p.224 e ss)
} 
absolutista para realizar seus objetivos políticos. Já neste tempo os juízes acreditavam no sistema normativo advindo de autoridades absolutistas ou eclesiásticas, e buscavam não competir com o legislador. O papel do Juiz era o de ser a voz do direito. ${ }^{15}$

No entanto, quando traz-se à baila a civilística alemã no século $\mathrm{XIX}^{16}$, ressalta-se a formação de um sistema lógico-formal, cuja principal colaboração acadêmica para o BGB (Bürgeliches Gesetzburch) ${ }^{17}$ foi dada pelo eminente pandectista Bernhard Windscheid que concebeu um código sistemático e teoricamente coerente no espírito dos pandectistas, com amplo conhecimento no direito público e estrutura sistemática a partir de princípios gerais até as normas específicas em Direito Civil, como a teoria dos contratos e contratos em espécie de venda.

O BGB, que aqui usamos como exemplo, desde sua parte geral (Allgemeiner Teil) até seu direito obrigacional e por fim as obrigações contratuais, demonstrou que esta codificação foi criada para conceber aprioristicamente conceitos formais e genéricos voltados para o indivíduo e com essa solidez, acabou por alçar a ciência jurídica alemã por vários países.

\footnotetext{
${ }^{15}$ A famosa expressão "boca da lei" e da obra de Montesquieu: O espírito das Leis XI.6: "Os juizes da nação são apenas a boca que pronuncia as palavras da lei, seres inanimados que não podem moderar nem sua força, nem seu rigor".

${ }^{16}$ Caenegem vai trazer ainda vários outros exemplos dos códigos iluministas germânicos, que para além do Código Napoleônico de 1804, tiveram importante papel na construção do Direito alemão e europeu, que aqui citamos apenas para ilustração no presente trabalho, já que nos interessa em algumas passagens o movimento pandectista na construção do Direito Civil: o Codex Bavaricus Civilis de Maximiliano José III da Bavária, promulgado na Alemanha em 1756; o Código Prussiano de Frederico Guilherme I Allgemenies Gesetzbuch gegründt auf das römish Recht em 1738 que ab-rogou todas as normas fora do código e baseava-se no direito romano; A obra de Samule von Cocceji que recebeu de Frederico II a incumbência de compilar um conjunto codificado de normas baseado na razão e no direito nacional. Tal obra que foi completada posteriormente Por Carmer e Svarez que culminaram num código prussiano Allgemeine Landrecht, código exaustivo e maciço que cobria não só o Direito Civil, mas também o comercial e o Direito Público (eclesiástico, penal e feudal); o Allgemeines Bürgerliches Gesetsbuch promulgado na Austria em 1811, inicialmente para as velhas terras hereditárias do império dos Habsburgos. Este Código austríaco excluía todo o direito consuetudinário existente e futuro, buscando em princípios naturais o preenchimento de eventuais lacunas. (CAENEGEM, R.C. Van. Uma introdução histórica ao direito privado. Tradução: Carlos Eduardo Lima Machado, 2a .ed, São Paulo: Martins Fontes 1999 , p. 172 e ss)

${ }^{17}$ CAENEGEM, op.cit., p.221
} 
Como já ressaltado o sistema lógico-formal preconiza a não contradição e a compatibilidade e completude. Para atingir esse nível a pandectistica alemã construiu, como já dito, um sistema baseado no desenvolvimento de conceitos, assim chamado, método construtivista. Aqui tem-se um modo de pensamento fundamentado na lógica dedutiva de proposições certas (conceitos) com intuito de resolver problemas jurídicos pela simples subsunção, denotando uma pretensa infalibilidade com qual, um sistema axiológico não coadunaria.

Então, voltando à ideia dos sistemas axiológicos parece que a incompletude é a tônica na significação do sentido neste tipo de arquétipo, porque além de inacabado é um sistema que opera aberto e dinâmico, propenso à evolução, o que sem dúvida eleva a própria ordem jurídica que assume essa estrutura dinâmica. Neste jaez, os princípios e axiomas podem modificar-se dentro de uma realidade histórico social.

Mas, haveria possibilidade de convergência entre a tópica e o pensamento sistemático? Leandro Zanitelli ${ }^{18}$ em primoroso resgate da obra de Theodor Viehweg, deduz que inicialmente não há compatibilidade entre os dois modelos, até mesmo pelo que se expôs até o presente nesta dissertação. Na visão do proeminente autor a comparação entre os pensamentos sistemáticos e o aporético leva a um antagonismo evidente. Contudo, numa concepção axiomática de sistemas e não numa realidade acabada lógico-formal abrir-se-ia um portal de possibilidades para a tópica.

Neste cenário, onde a insuficiência oferecida por um sistema de valores e sentidos, cuja lógica exige sempre novas valorações dentro de contextos evolutivos, a verdade é que não há como se dimensionar totalmente o sistema normativo quanto a seus valores, justamente pela caraterística e falibilidade própria dos sistemas valorativos.

\footnotetext{
${ }^{18}$ C.f. em: tópica e pensamento sistemático: Convergência ou ruptura. In: COSTA, Judith Martins. A reconstrução do direito privado: reflexos dos princípios, diretrizes e direitos fundamentais constitucionais no direito privado. São Paulo: Editora RT, 2002 p. 137 e ss.
} 
Assim, a tópica surge como verdadeira ferramenta para concretização de princípios, conceitos abertos ou até indeterminados e cláusulas gerais.

Nessa medida a aplicação de topoi aparece como direcionador das premissas ou pontos de vista que se pretende aplicar no caso ou problema diante da não suficiência do sistema, onde parece haver aceno para uma convergência.

Ora, seja na concretude de um problema que suscita norma material, que por sua vez possui um conceito indeterminado um conjunto de princípios fundamentais elencados na norma constitucional, de fato os topoi aplicados como integradores do sistema, são vagos, e nem sempre conduzirão a conclusões estanques, mas seja como for serão pontos de vista orientadores do pensamento, ainda que sendo objeto de críticas.

A tópica aqui não aparece para preencher desvios ou incongruências do sistema, mas tão somente se abre como um novo tipo de raciocínio, totalmente voltado à adequação por construção de premissas e à unidade do sistema. Neste contexto então, ressalta Zanitelli ${ }^{19}$, como força contrária ao pensamento sistemático, a tópica relacionase estreitamente à equidade ou à justiça do caso concreto. E ligada a um juízo de equidade a tópica assume uma tendência individualizadora da justiça.

Em tal tendência, no Direito Civil especificamente, a tópica assume o papel de preenchimento de normas, não suficientemente integradas pelo sistema axiomático, de modo que a utilização de topoi para concretização da norma enquanto preceito contido no contexto codificado poderá ser realizado com a formulação de premissas visando resolver o caso ou problema in locu.

De fato, não se pode olvidar que a realização desta integração não se dará inexoravelmente pela tópica em todos os conceitos indeterminados, normas em branco,

\footnotetext{
${ }^{19}$ C.f. em: tópica e pensamento sistemático: Convergência ou ruptura. In: COSTA, Judith Martins. A reconstrução do direito privado: reflexos dos princípios, diretrizes e direitos fundamentais constitucionais no direito privado. Idem, ibidem.
} 
cláusulas gerais como resposta a não totalidade de abrangência pelo sistema axiológico. Deve-se considerar que existe forte tendência também à sistematização de vários compartimentos do Direito Civil, mormente, num processo comunicacional colmatado com preceitos constitucionais em caráter sistemático, guiado por um caminho teleológico o que sem dúvida, culmina na clara valoração normativa a partir da comunicação entre sistemas internos jurídicos, ou sistemas parciais do Direito.

Essa realidade foge da simples criação de constructos alicerçados em premissas, isto é, como mera conjugação de pontos de vista. Vai além, porque se considerar-se a tópica como raciocínio voltado para o problema em substituição do próprio sistema axiológico, esta mostra-se absolutamente antagônica com o pensamento sistemático.

Logo, não é possível que se entenda que na falta de integração axiológica haja mera substituição pela tópica. É preciso entender que se trata de uma alternativa que é barrada em vários pontos do Direito Civil por esta tendência à sistematização que, no que se pode sentir, dá-se por processos comunicacionais.

Mas, isso por si só não afasta a possibilidade de aplicação de um método tópico-sistemático num contexto de transição de um direito estritamente privado, para um modelo civil-constitucional. Contudo, talvez seja necessário avançar um pouco mais, na análise porque o sujeito, a sociedade, hão de ser considerados nesta formatação.

Assim, avançando um pouco mais, em especial quanto ao Direito Civil no Brasil, existe ainda importante questão que não pode ficar desmerecida nesta breve explanação quanto ao método de pensamento a ser aplicado: suas fontes, em acepção ampla, com a consciência de que o fenômeno jurídico não se exaure apenas em fontes legislativas (normativas) ou jurisprudenciais. 
Perlingieri acentua que a consciência do Direito busca identificar-se com a experiência global do social ${ }^{20}$ o que certamente amplia a discussão sobre a implementação de um modo pensamento, ainda que assumindo a convergência entre um método tópicosistemático.

E na razão direta de um pretenso Direito Civil Constitucional, onde evoca-se um processo de transição, certamente tal mudança de consciência perpassa por uma modificação de seus princípios básicos e seus escopos gerais para um novo atrelamento sistêmico que numa relação, ainda compreendida como hierárquica em face do constitucionalismo, de alguma forma vocaciona o Direito Civil a redimir-se de sua individualidade, de seu egoísmo sistêmico que caracteriza a sua existência sobretudo a partir de uma desprestigiada codificação, para um modelo que acima de tudo prima pela pessoa humana, sua dignidade e sua centralidade existencial.

E para efeitos deste trabalho a análise do sujeito enquanto destinatário deste direito civil constitucionalizado, indubitavelmente, para além de um método explicativo do fenômeno (seja tópico ou sistemático), dependerá também de um escorço breve, abrangente, mas objetivo no sentido de caracterizar não somente o fator comunicacional entre os sistemas, mas também, os processos de restabilização de expectativas congruentes que ao que tudo indica, passam inexoravelmente por uma volta em torno de princípios constitucionais humanitários, fundamentais, mormente, a partir do constitucionalismo no século XIX onde a liberdade e a igualdade do cidadão são forças motrizes do desenvolvimento no sistema de direito privado. Voltaremos a este assunto nos estudos sobre os avanços do Direito Civil em campo constitucional.

Assim, antes até de adentrar aos meandros da condição do sujeito de direitos considerado aprioristicamente como parte de uma realidade social mesmo que o Direito

\footnotetext{
${ }^{20}$ PERLINGIERI, Pietro. O Direito Civil na legalidade Constitucional. Tradução: Maria Cristina de Cicco. Rio de Janeiro: Renovar, 2008, p. 58 e ss.
} 
o tenha condicionado a um processo primo de abstração para conceituação do sujeito ${ }^{21}$ (Dal soggetto alla persona e Dal persona alla soggeto) como o receptor do sistema normativo dotado de sentidos e valores, o fato é que em extrato elevado está a sociedade hipercomplexa em constante evolução.

Daí a necessidade de um pequeno esclarecimento, mesmo dentro de um modelo já admitido como tópico-sistemático, de que o modelo de sistema a ser consideração, será pautado pelo critério axiomático e não abstrato-genérico, porém, com sua evolução valorativa explicada à luz da teoria dos sistemas de Luhmann.

\subsection{A concepção de sistemas em Luhmann como modelo demonstrativo do processo evolutivo do Direito e da sociedade}

A par da teoria dos sistemas de Luhmann, que aqui serão usadas, tão e somente só, para demonstrar o indissociável processo evolutivo tanto do Direito quanto da sociedade na ideia de um processo de comunicação sistêmica que conduz a sociedade moderna em sua evolução e à diferenciação. Neste ponto é de bom tom esclarecer que não é em entendimento deste autor, o contrário. Trata-se de um cenário de complexificação da sociedade moderna a partir da restabilização de expectativas congruentes com o modelo jurídico adotado no contexto desta.

Nesta visão a evolução como um todo ocorre quando a restabilização de processos desviantes passa a integrar o respectivo sistema (social ou jurídico) transformando o improvável em provável. Ou seja, torna plausível a probabilidade de que

\footnotetext{
${ }^{21}$ RODOTÀ, Stefano. Il diritto di avere diritti. Roma-Bari, Editori Laterza, 2012, p. 140.
} 
determinado evento antes impensado ou improvável vá se sedimentar ou se estabilizar como uma expectativa congruente ${ }^{22}$, adaptável aos elementos já existentes.

Em irretocável explanação o professor $\mathrm{Neves}^{23}$ destaca que a evolução sistêmica se dá na teoria luhmaniana baseada em três condições: variação, seleção e restabilização ou retenção a que chama de "mecanismos ou funções da evolução".

A variação, na explicação do Ilustre professor, consiste numa perspectiva reprodução desviante dos elementos que vão surgindo dentro do sistema. Sob este prisma há ruptura com o que já existia através do surgimento de perspectivas desviantes do que já estava estabilizado. Mas, isso por si só não é a evolução, porque no plano estrutural, o sistema pode reagir negativamente a essa variação.

Desta forma a seleção das estruturas se faz necessária como mola, engrenagem para propiciação da reprodução do sistema. É a partir da variação que o sistema se abre à evolução e inicia o processo de continuidade da evolutiva. Este caminho vai chegar a termo com a restabilização como mecanismo de fixação das expectativas inovadoras variadas e selecionadas, dando a nova estrutura "duração e capacidade de resistência. " ${ }^{24}$ No modelo proposto pela teoria de Luhmann esses eventos estarão atrelados ao grau de evolução e complexidade.

Importante aqui, afastar qualquer tipo de dúvida ou condução indevida do raciocínio do exegeta e do leitor de que se tenha levado em consideração como paradigma

\footnotetext{
${ }^{22} \mathrm{E}$ aqui Luhmann determina que nos novos preceitos de sua teoria, seria deixado de lado na abordagem do tema das expectativas a distinção sujeito/objeto, substituindo essa racionalidade por uma diferenciação entre operação/observação, sendo que a operação é o que um sistema realiza de fato no processo de abertura para evolução e autopoiese; a observação pode ser efetuada pelo próprio sistema, ou por outro. Logo não se trata de mera operação de imput/output, mas antes a capacidade de generalização do sistema. Assim, o conceito de expectativa a princípio não se dirige ao componente subjetivo, ou seja, ao sujeito, o que determinaria a análise "de cima" a que nos referimos no trabalho. (LUHMANN, Niklas. Introdução à Teoria dos Sistemas. Aulas publicadas por Javier Torres Nafarrate. Tradução: Ana Cristina Arantes Nasser. 2.ed. Petrópolis/RJ: Vozes, 2010, p.325)

${ }^{23}$ NEVES, Marcelo. Entre Têmis e Leviatã: uma relação difícil: o Estado Democrático de Direito a partir e além de Luhmann e Habermas. Op.cit., passim.

${ }^{24}$ Luhmann e De Giorgi, 1992:190; $c f$. Luhmann, 1997:454 e ss, apud, NEVES, op. Cit. p. 2
} 
desse sistema teorético qualquer vinculação com teorias lastreadas pela preocupação com a estrutura orgânica e psíquica da existência humana. Teorias biológicas ${ }^{25}$ ou biossociológicas, portanto, estão afastadas.

Prefere-se aqui o entendimento de que a evolução sistêmica, mormente de sistemas sociais, se dá a partir de processos comunicacionais que emergem "de cima" ${ }^{26} \mathrm{o}$ que se afasta em consequência, de qualquer postura sociobiológica que tem uma visão de emergência de " baixo, ou seja, a partir do indivíduo. Haverá no trabalho um momento em que será tratado o sujeito de direitos como destinatário deste processo de evolução sistêmica. Mas, até se chegar a ele o cadenciamento dos eventos que emergirão do processo de comunicação entre sistemas se dará em plano abstrato e superior.

Essa concatenação de raciocínio, talvez seja crucial para esclarecer que não nos conformamos com a atual análise de um processo de evolução do Direito Civil para um Direito Civil-Constitucional, apenas com o constructo de uma ponte de interseção

${ }^{25}$ E ao explicar a autonomia e autopoise do ser vivo em sua organização, Maturana e Varela, buscam em bases biológicas, inspiradoras do pensamento inicial de Luhmann, dentre outras coisas quando asseveram: A caraterística mais peculiar de um sistema autopoiético é que ele se levanta por seus próprios cordões, e se constitui como diferente do meio por sua própria dinâmica, de tal maneira que ambas as coisas são inseparáveis. O que caracteriza o ser vivo é sua organização autopoiética. Seres vivos diferentes se distinguem porque têm estruturas distintas, mas não são iguais em sua organização. O reconhecimento de que aquilo que caracteriza os seres vivos é sua organização autopoiética, permite relacionar uma grande quantidade de dados empíricos a respeito do funcionamento celular e sua bioquímica. A noção de autopoise, portanto, não está em contradição com esse corpo de dados. Ao contrário, apoia-se neles e se propõe, explicitamente, a interpretar esses dados a partir de um ponto de vista específico, que destaca o fato de que os seres vivos são unidades autônomas (MATURANA, Humberto R; VARELA, Francisco J. A árvore do conhecimento: as bases biológicas da compreensão humana. Tradução: Humberto Mariotti e Lia Diskin. São Paulo: Palas Athena, 2001, p.55

${ }^{26} C f$. Neves, op.cit., p. 40, quando cita os sistemas sociais em Luhmann para determinar seu caráter autopoiético, demonstrando que suas estruturas operacionalizam num plano superior, uma nova diferença entre sistema e ambiente. Assim, não queremos aqui nesta dissertação que haja a errônea compreensão de que partimos de um modelo evolutivo, para determinar a hipercomplexidade social, que tenha tido seu arcabouço no acúmulo de experiências da consciência humana, tal qual Maturana e Varela e seu sentido biológico com a autopoiese de primeira, segunda e terceira ordem, partindo de uma nuance puramente evolutiva dos organismos. Talvez, seja até importante esclarecer, desde já, que no desenvolvimento de um Direito Civil constitucional, a própria autonomia da vontade se vê, atualmente evoluída e fragmentada pelo sentido normativo ditado pelo sistema constitucional, principalmente na teoria obrigacional e contratual. Desta feita, entender a autonomia como um sentido imanente do consciente humano, esbarra na realidade de sua submissão à norma condutora que por sua vez, constróise e reconstrói-se pelo que entendemos ser um processo autopoeitico, tal qual descrito na teoria Luhmaniana, em plano distante da consciência, porém, voltado para restabilização de valores congruentes com o consenso social, paradigmado em primados constitucionais. 
entre princípios norteadores constitucionais sobrepostos a princípios e regras de segundo $\operatorname{grau}^{27}$ do Direito Civil, como que, a pretexto de satisfazer direitos fundamentais e humanos, mormente a dignidade da pessoa humana, impõe-se a todo o sistema civilístico para o submeter a uma nova hermenêutica calcada no constitucionalismo.

Há no centro dessa ponte que se analisar como um lado chegou ao outro. Obviamente que não se debruçará por tão tormentoso objeto a fim de tentar explicar a teoria dos sistemas como a resposta, porém, o socorro aos seus preceitos como tentativa de lançar alguma luz ao problema dos processos que estão desencadeando essa evolução dos sistemas parciais (constitucional e civil) nos parece adequada.

Feito esse importante esclarecimento e ainda escorado na visão lúcida do professor $\mathrm{Neves}^{28}$, pelos critérios de formação do processo comunicacional (variação, seleção e restabilização) o modelo estrutural da sociedade hipercomplexa evolui em autopoiese a partir de expectativas congruentes, porém, surpreendentes ou inesperadas. Essas expectativas que num modelo sistêmico valorativo, poderiam corresponder a determinados axiomas introduzidos num contexto estabilizado, representando uma negação de todas as estruturas estabilizadas.

E é primordial explicar que este processo de negação, no plano estrutural do sistema social, compreende a um processo também de orientação da comunicação, porque se há na variação a negação ou o rejeito explícito da expectativa desviante em prol da manutenção do que já havia, ou se há negação do que já havia em face do comportamento desviante, há início de evolução. Seria inconcebível a absorção de todo comportamento desviante, o que sem dúvida, levaria o sistema a engendrar por um processo tão fechado que por si só o encerraria nas vias do solipsismo vindo colapsar pela desestruturação.

${ }^{27}$ Cf. ÁVILA, op.cit.passim

${ }^{28}$ Idem, ibidem. 
Mas é claro que, por este modelo, a seleção de condutas desviantes no seio social gera a assimilação da ocorrência do valor, o que é imprescindível para o acontecimento evolutivo do sistema social, mas não é por si só a evolução. A restabilização dessas novas estruturas sociais no complexo das já existentes importa na aceitação do que antes era inaplicável e improvável de uma forma dinâmica com a compatibilização dessas novas expectativas com o sistema.

O escopo de tal processo induz a consistência do próprio sistema e a capacidade de resistência das novas estruturas dependerá disto, porque se forem incorporadas, passarão a fazer parte da unidade do sistema, serão estruturas autoreferenciais para novos processos de abertura comunicacional.

Apesar de falar-se aqui a todo tempo em sociedades hipercomplexas, não se pode olvidar que não é regra imponível pela exceção, porque existem sociedades menos complexas onde o grau de evolução e complexidade o desvio é tido como algo estranho e não aceitável de modo que os elementos e estruturas da sociedade não se diferenciam, tal e qual ocorre com a variação e seleção. Mas, trata-se de mera observação neste contexto trabalhado.

Todavia, na sociedade moderna a diferenciação funcional é característica inarredável, quiçá um pressuposto, para que em sistemas autônomos ocorra uma fragmentação estrutural (expectativas), até mesmo em sistemas parciais. A unidade do sistema na modernidade é dinâmica e, por processos comunicacionais consegue claramente diferenciar seleção e restabilização em sociedades mais complexas.

Para o trabalho que está se desenvolvendo imperioso colocar já neste momento da explanação que o método de pensamento, mesmo já admitindo-o como tópico sistemático, somente encontrará fundamento e conexão com os processos de transição do Direito Civil dentro de um modelo de comunicação de sistemas parciais 
jurídicos e o sistema social, admitindo-se que no seio pátrio apesar de o Brasil ser um país considerado periférico para a maioria dos países desenvolvidos, ainda assim a sociedade brasileira, com as devidas ponderações, pode se inserir no contexto de modernidade, fragmentária e complexa.

Considerando particularmente a dinâmica comunicacional em Lhumann como perfeitamente plausível para ao menos determinar um método de pensamento sistemático para os mecanismos de evolução sistêmica jurídico-social é que se almeja embasar a argumentação a partir deste ponto de vista.

E é interessante, porque ao se buscar alguns paradigmas que de alguma forma inspiraram a construção Luhmaniana neste trabalho, vê-se saltar aos olhos a presença da evolução da própria autonomia privada em seara obrigacional, considerando aqui seu sentido lato e encerrado no contexto negocial do ato jurídico stricto senso.

Em Durkheim ${ }^{29}$ e sua solidariedade orgânica a evolução social antes de tudo parte de uma estrutura organizada onde há o desaparecimento do segmentarismo. Existe um verdadeiro significado moral neste contexto definido nesta análise sociológica como sentimento de solidariedade.

A solidariedade em sentido lato também aponta para uma conjunção de valores comungados pelo corpo social, que em Direito Civil vão comutar-se em cláusulas gerais fomentadoras da boa-fé em sentido objetivo. "Quanto mais desenvolvido está o sistema alveolar, mais as relações, nas quais cada um de nós está comprometido, se encerram nos limites do alvéolo a que pertencemos"30.

Neste mesmo cenário, Durkheim objeta como diretamente proporcional o aumento do volume da sociedade e a divisão do trabalho, não pelo simples aumento, mas

\footnotetext{
${ }^{29}$ DURKEIM, Emilie. A Divisão do trabalho social. $2^{\mathrm{a}}$ ed, Editorial Presença LTDA, tradução: Eduardo Freitas e Maria Inês Mansinho, Lisboa: s/d, p.30.

${ }^{30} \mathrm{Idem}$, ibidem, p. 36.
} 
pela luta pela vida, trazendo agora uma ideia não simplesmente moral, mas relacionada com uma interação que apenas toca, sem adentrar, a questão da econômica, mormente a capitalista, como oposta e geradora de tensão nesta relação de solidariedade.

Esta estrutura chama a atenção, porque em prol de uma vida moral e em sociedade, tem-se a divisão do trabalho, mesmo que distanciada da realidade do sistema econômico, como a mola propulsora da unificação do sistema social. Assim a vida moral circula na visão do autor citado, em todas as relações que a constituem fundada em sentimentos de unificação do social e morais. Existe aí o portal aberto para a formação de um plexo de normas controladoras da sociedade, com estrutura axiomática e resultantes objetivas/sancionadoras.

Numa palavra, para que o controlo social seja rigoroso e a consciência comum se mantenha, é preciso que a sociedade esteja dividida em compartimentos bastante pequenos, que envolvam completamente o indivíduo, caso contrário, ambos enfraquecem, à medida que essas divisões desaparecem ${ }^{31}$.

E sobressalta à análise o quanto essa ideologia tangencia a própria construção da autonomia privada, em breve ilustração, porque mesmo no entendimento mais simplista desta como sendo a manifestação da consciência individual em torno da construção de um negócio jurídico, não se pode negar em momento algum que essa manifestação da consciência se dá em ambiente social, logo, permeada por uma série de normas controladoras sociais.

Essas por sua vez, são resultado de restabilização de estruturas no sistema social dinamicamente e congruentemente aceitas no processo de variação. Nesta dimensão Durkheim explica a divisão do trabalho social em sociedades orgânicas, logo funcionalmente diferenciadas tendo o Estado como órgão central, formulando aí uma

\footnotetext{
${ }^{31}$ DURKEIM, Emilie, op.cit., p. 87.
} 
sociedade estruturada politicamente e socialmente integrada por regras morais. Luhmann faz críticas a esse modelo, apesar de o encarar como aquele que desnuda o problema a ser enfrentado.

Já em Weber ${ }^{32}$, outro paradigma, a modernidade anuncia o processo de racionalização da sociedade. Ao tratar sobre suas teorias de dominação legítima, também fica claro que a modernidade implica numa racionalização-com-respeito-a-fins-da conduta e valores. Tudo em detrimento dos fundamentos tradicionais e voltados para uma ética fundamentalista, calcada em preceitos morais e religiosos comungados. Mas, em sua estruturação, alerta Weber para a natureza do Estado Moderno como uma relação associativa institucional, segundo determinado conjunto de regras num contexto normativo, regras estas de divisão de poderes e limitações destes, assentadas em preceitos gerais que formam um complexo sistema enraizado em preceitos jurídicos parciais para determinação do próprio sistema jurídico. ${ }^{33}$

Esse enfoque weberiano denuncia ainda que o processo de diferenciação das concepções fundamentais jurídicas está alicerçado em fatores jurídicos, mas também políticos. Para Weber, o sistema econômico atua apenas indiretamente na racionalização da economia, pelo livre mercado e a livre contratação - o que certamente, nesta visão faz nascerem conflitos cada vez mais complexos em seara de negócios jurídicos- que se dá de forma absolutamente dissociada da estrutura estatal a qual promove o desenvolvimento de uma racionalidade especificamente jurídica.

Essa dissociação com o sistema econômico o conduz, na visão do autor citado, a existir independente da estrutura estatal condicionado por situações concretas oriundas do ambiente econômico, e que por isso jamais podem ser inseridas num contexto

\footnotetext{
${ }^{32}$ WEBER, Max. Economia e sociedade: fundamentos da sociologia compreensiva. Tradução de Regis Barbosa e Karen Elsabe Barbosa; Revisão técnica de Gabriel Cohn, vol II. Brasília, DF: Editora Universidade de Brasília: São Paulo: Imprensa Oficial do Estado de São Paulo, 1999, passim.

${ }^{33}$ Weber, op.cit.p. 15
} 
de um sistema normativo de regras gerais e tão pouco, assim pensa este autor, calcado em valores. Em Luhmann esse constructo de racionalidade envolve diferenciação funcional. Por estes prismas paradigmáticos a teoria luhmaniana entende o modelo de sociedade moderna considerada complexa, por essa presença permanente de mais alternativas, para além das que se apresentam como possível. Trata-se aqui de contingenciamento, porque a complexidade implica naquele. Mesmo considerando o problema desnudado em Durkheim quanto a divisão do trabalho ou a separação weberiana do sistema econômico do sistema jurídico, este neutralizado por seus fins morais, salientase uma evolução alavancada por esta complexidade no seio social, tensionada por um número aleatório de ações, possibilidades, diversidades num motor em funcionamento contínuo. Adverte-se o leitor deste texto que essa constante evolução não coaduna com a ideia de um incremento infinito de complexidade, sob pena de se criar uma evolução com tendência a paradoxos, assim, insustentável.

O comportamento em especial do Direito Civil neste contexto não pode ser outro senão o de acompanhar esta evolução com a mesma dinâmica com que ocorre no sistema social, porque mormente no seio da norma privada reside uma plêiade de princípios e regras que conduzem a vida do sujeito de direitos.

Num cenário de grande complexidade, fragmentação social e necessidade de diferenciação funcional, os processos comunicacionais entre sistemas parciais jurídicos, aqui Civil-Constitucional, a priori pode-se dizer, ocorrem em plano heterárquico diferentemente do que muitos autores deduzem em suas explanações sobre o fenômeno da constitucionalização do direito civil.

Neste encadeamento, em que pese haver desníveis entre os sistemas, seus ambientes e não se negar a supremacia e força normativa constitucional ${ }^{34}$, ainda assim,

\footnotetext{
${ }^{34} C f$. Hesse que elucida este mínimo ponto evocando a força ativa da constituição substancial: Mas a força normativa da Constituição não reside, tão-somente, na adaptação inteligente a uma dada realidade. A
} 
nota-se que o sistema de normas civilisticas, a par de seu desnível com o sistema constitucional, não busca validade neste, mas adequação com seus preceitos no plano hermenêutico. A restabilização de expectativas normativas aqui se dá norteada por vetores principiológicos que advém do sistema constitucional substantivo e em constante evolução. Em curtas palavras, nesta inicial colocação, o Direito Civil realiza seu mister, porém, desancorando-se cada vez mais de preceitos vetustos e imutáveis e realizando o significado de suas normas segundo a própria substancialidade e prospecção do sistema constitucional, mantendo com este, contínua comunicação em nível heterárquico.

Agora, ao se tratar de uma supercomplexidade na teoria sistêmica que se abraça neste trecho, é preciso compreender que o contingenciamento numa sociedade supercomplexa é um contingenciamento complexo por consequência. Desta forma a abertura para o futuro é essencial à continuidade do processo de evolução dos sistemas.

Porque nenhum processo comunicacional pode se operar tão fechado que não se abra para o futuro buscando a partir da própria restabilização, elementos para novas seleções e variações, porque neste viés não haveria evolução.

Um sistema, ainda que parcial, possui seu ambiente que sofre com que Luhmann denominou de irritações por parte de outros de outros sistemas. Há desnível de complexidade entre o sistema e seu ambiente o que pressupõe impulso para evolução, porque existirá sempre um movimento de continuidade para consecução das fases do processo comunicacional.

\footnotetext{
Constituição jurídica logra converter-se, ela mesma, em força ativa, que se assenta na natureza singular do presente ( individuelle Beschaffenheit der Gegernwart). Embora a Constitução não possa, por si só, realizar nada, ela pode impor tarefas. A Constituição transforma-se em força ativa se essas tarefas forem efetivamente realizadas, se existir disposição de orientar a própria conduta segundo a ordem nela estabelecida, se, a despeito de todos os questionamentos e reservas provenientes dos juízos de conveniência, se puder identificar a vontade de concretizar essa ordem. (HESSE, Konrad. A força normativa da Constituição. Tradução: Gilmar Ferreira Mendes. Porto Alegre: Sergio Antonio Fabris Editor, 1991, p. 19)
} 
A hipercomplexidade envolve também pressão seletiva que importa supercontingenciamento, que por sua vez, provoca a diferenciação social. Isso se dá porque a contingência gera riscos ${ }^{35}$, desenvolve aquilo que professor Neves conceituou como uma sobrecarga seletiva que vai exigir divisão em sistemas parciais, diferenciados e autônomos por si só.

Este processo de diferenciação sistêmico-funcional não necessariamente reduz a complexidade, mas pode até aumentar a abertura para o futuro. A questão se resolveria, na visão crítica de Marcelo Neves, pela eficiência dos sistemas parciais funcionais nos processos de comunicação com seus ambientes. Mas, deixe-se essa última questão para uma análise em apartado num trabalho que vise apenas esse objeto.

A par desse entrecho de evolução que se busca demonstrar singelamente, a ciência jurídica buscou evoluir na sociedade moderna, hipercomplexa e defrontou-se, por conseguinte com um cenário moderno de policontexturalidade que por sua vez a encaminhou para reformulação de seus próprios escopos.

Nessa transição para uma sociedade moderna, o que se nota é que do direito natural ao direito positivo, com ordens jurídicas diametralmente opostas a ciência jurídica firmou sua pretensão de validade em paradigmas diferentes, porém, em escala evolutiva. Aqui já se desnuda um processo de evolução sistêmica, onde os acoplamentos entre sistema social e jurídico sedimentam-se em expectativas fundadas na própria complexidade do processo evolutivo social em cada momento. Assim, em apertada síntese, vamos delinear abaixo alguns dos passos dados pela ciência jurídica neste caminhar até o contexto atual.

Desta feita numa singela, mas necessária digressão sobre o jusnaturalismo cuja concepção desempenhou importante papel no próprio desenvolvimento de um direito

\footnotetext{
${ }^{35}$ Aqui o risco da decisão oriunda da seletividade das expectativas mais congruentes no contexto do sistema.
} 
positivo, o que se via era uma ciência calcada em pilares positivados cuja mutabilidade, a par de um ius divinum voluntarium subordinava-se a preceitos imutáveis calcados em valores abstratos, dogmas, por si só.

O direito natural em sua fase moderna concebia um corpo de princípios básicos dos quais o direito positivo derivar-se-ia, ou seja, aos quais estaria subordinado. Inclusive, vale ilustrar, na moderna escola jusnaturalista, muitos de seus pensadores recusavam-se a conceber as normas de direito positivo ou a própria atividade legiferante, a partir de preceitos encerrados em sistemas externos como o direito divino ou o corpo iuris. Buscavam antes no desenvolvimento de estudos racionais e críticos da natureza humana evidenciar uma gama de princípios axiomáticos, dos quais se pudesse deduzir o direito positivado.

Citando Hugo Grotius, Caenegem ${ }^{36}$ vai ressaltar os estudos daquele em suas obras Mare Liberum (1609) e de iure belli ac pacis libri três (1623) sobre como tentou buscar fundamento para os direitos nacionais com bases principiológicas universalmente reconhecidas. Essa contextualização, com alicerces fincados numa racionalidade consensualista, descobriu uma noção indispensável ao direito natural moderno: as normas básicas, assim como os princípios norteadores deveriam ser aceitos por todos os homens e Estados admitidas como princípios da natureza humana e constituiriam a base para a operação legiferante.

Tais normas seriam válidas independentemente de um ordenamento divino ou do próprio direito romano. Além disso, tais normas seriam independentes de qualquer $\operatorname{legislador}^{37}$, pois nenhuma autoridade ou instância supranacional poderia reivindicar a criação e a imposição do sistema normativo.

\footnotetext{
${ }^{36}$ CAENEGEM, op.cit.p.165 e ss.

${ }^{37}$ Idem, ibidem. E aqui importa destacar que na visão de Grotius um processo de universalização se daria pelo consenso dos princípios. Não deixa de ser um prelúdio do que veríamos hoje numa sociedade
} 
Em Pufendorf ${ }^{38}$, e sua obra De iure naturae et gentium libri VIII (1672) o jusnaturalismo é visto como um sistema racional, laico, livre de dogmas religiosos calcado na dedução como norteadora da construção de normas gerais. Neste jaez o que se vê é forte influência do pensamento científico da época, em especial, Descartes e Galileu. A observação citada nessa vertente parte da busca pela verdade evidente no empirismo com rigorosa observação científica.

Ainda que para alguns o espírito das leis de Montesquieu não seria um tratado de direito natural, mas um estudo filosófico sobre a legislação cujo papel teria se atido às instituições públicas e suas naturezas intrínsecas ${ }^{39}$, seja como for o estudo proposto pela obra reveste-se de toda importância porque evidencia um plano para construção de um sistema normativo, sem qualquer ligação aos sistemas de Luhmann, mas que de qualquer forma se conforma numa constante evolução.

Seja sob o prisma que se olha a obra do grande jusfilósofo, apreende-se de seu pensamento que a formulação das leis, homenageando a significância dada à época de sua obra e vida (1689 a 1755), advém do entendimento de que são relações necessárias entre a razão dos seres em si, relações estas que não advieram da "cega fatalidade" $40 \mathrm{com}$ produtora dos resultados, mas antes advém da natureza das coisas.

De toda sorte a leitura básica da obra de Montesquieu, mormente o livro I, que se debruça a análise neste instante, denota a ideia elementar de um equilíbrio de leis que superam a esfera humana, talvez oriundas de Deus na visão teocrática de seu pensamento, mas que não impede que os seres, inteligentes que são criem suas próprias

absolutamente inserida em processos dinâmicos de diferenciação, fragmentação e consequentemente, num cenário atual de policontexturalidade.

38 CAENEGEM, idem, ibidem.

${ }^{39}$ MONTESQUIEU, Charles de Secondat, Baron de. Do Espírito das Leis. Tradução: Roberto Leal Ferreira. São Paulo: Martin Claret, 2010, passim.

${ }^{40}$ MONTESQUIEU, idem ibidem 
leis baseadas num ideal de justiça que sempre esteve além da compreensão humana, porém, perseguido por ela.

Daí a concepção implícita de evolução do Direito, diante da certeira e invariável assertiva de que os seres inteligentes, os homens por assim dizer, são falhos, violam sem cessar as leis de Deus e as suas próprias sujeitando-se a sanções que na esfera divinal o acorrentam em vida a sua própria consciência, e perante as leis humanas o submetem a deveres políticos e civis.

Em tal enredo, Montesquieu assevera que anterior a essas leis estão as da natureza, assim chamadas por ele em relação ao homem num egoísmo anterior à vida em sociedade. Logo, tais leis chamadas de naturais pelo Mestre não remetem a uma natureza de coisas mas imprimem a ideia do Criador pela religação da consciência do homem em estado de natureza e o Deus que a tudo originou.

Sem querer propor qualquer interpretação da obra, de fato Montesquieu propõe o conjunto de normas, sem falar-se em sistemas, como resultado da razão humana. Essas normas, ali chamadas de leis, convergem-se para a construção da nação e de seu povo, observando preceitos relacionados à liberdade e igualdade, tendo por fonte emanadora das bases racionais, porque não de princípios, a constituição.

Tais leis devem relacionar-se com a natureza e o princípio do governo estabelecido o que se pretende estabelecer, quer o formem com as leis políticas, quer o mantenham, como as leis civis.

Devem estar relacionadas ao físico do país: ao clima gelado, tórrido ou temperado; à qualidade do solo, à sua situação, ao tamanho; ao gênero de vida dos povos, lavradores, caçadores ou pastores.

Deve relacionar-se com o grau de liberdade que a constituição pode tolerar; com a religião dos habitantes, com as inclinações, com as riquezas, com o número, com o comércio, com os costumes, com os comportamentos $^{41}$.

\footnotetext{
${ }^{41}$ MONTESQUIEU, op.cit. p.26 e ss
} 
$\mathrm{Kant}^{42} \mathrm{em}$ sua crítica à razão pura tece importantes observações a respeito da criação de leis naturais que fundamentassem a liberdade do ser, bem como a autoridade do legislador. Trata-se de uma fundamentação jusracional da própria validade do Direito. O pensamento espraiado na obra deste pensador conduz ao status de dever moral a observância às leis: "é preciso sair do estado de natureza, no qual cada um segue sua própria ideia, unir-se a todos os outros (com os quais ele não pode evitar entrar em interação) e submeter-se a uma coação externa e pública” que explicada pelo autor em sua obra remete ao ingresso num estado onde cada um se determina legalmente e se atribui mediante o que Kant chamou de poder suficiente externo, um estado civil como dá entender.

Citando a obra de Hobbes, em outro trecho de sua crítica ainda assevera:

Tal como Hobbes afirma, o estado de natureza é um estado de violência e de prepotência e devemos necessariamente abandoná-lo para nos submetermos à coação das leis, que não limita a nossa liberdade senão para que possa conciliar-se com a liberdade de qualquer outro e, desse modo, com o bem comum ${ }^{43}$.

A presença de uma lei natural como fundante e normatizante da própria liberdade, para Kant submeterá os fenômenos e seus efeitos ou causas aos seus efeitos condicionantes, o que sem dúvida aponta, mesmo no seio do jusnaturalismo, para um sistema normativo submetido a uma norma fundamental apriorística que em Kant não encontra amparo em simplistas fundamentações sobre uma lógica teocrática ou solipsista da razão.

A natureza é então a causa completa e por si só suficiente, determinante de cada acontecimento, e a condição de cada um deles está sempre contida, unicamente, na série dos fenômenos que, juntamente com os seus efeitos, estão necessariamente submetidos à lei natural ${ }^{44}$.

\footnotetext{
${ }^{42}$ KANT, Immanuel. Crítica da Razão Pura.Tradução: Manuela Pinto dos Santos e Alexandre Fradique Morujão. Lisboa/Portugal: Fundação Calouste Gulbenkian, 5.ed., 2001, passim.

${ }^{43}$ KANT, op.cit. p.616

${ }^{44}$ Idem, p.477
} 
Já no positivismo, a racionalidade, assim como o processo evolutivo do sistema jurídico, toma novo sentido para os critérios de validação da norma e logicamente influenciam a própria sociedade, dimensionando a própria ciência jurídica num novo espectro de análise de seus objetos.

Alexy $^{45}$ inicia sua análise da visão positivista quanto ao conceito de Direito explicando com base em autores como Theodor Geiger e Max Weber que a construção deste preceito positivado se daria com um aspecto externo e interno, sendo o externo a própria regularidade da norma por via de sua observância ou submissão à sanção (tanto positiva quanto negativa), experimentando na visão weberiana a noção de coação como ação dirigida à obtenção de punição para a não observação de uma norma emanada de órgão estatal competente para cria-la. Em seu aspecto interno a norma consistiria na motivação calcada no reconhecimento recíproco de valores que uma vez adotados pela sociedade e traduzidos ao mundo jurídico se comutariam em regras jurídicas.

Mas, se por um lado o Direito se apresenta como um conjunto de normas delimitadoras da convivência social, de outro lado sua validade é condicionada à sua relação com a validade social das normas criadas, além da validade destas normas perante a validade moral das mesmas. Assim, naquilo que Alexy determinou como uma circularidade $^{46}$ entre o conceito de Direito e sua validade, vai se desfazer pelo incremento da norma fundamental.

Em Kelsen ${ }^{47}$, como já sabido de muitos, a norma fundamental é o ápice de todo o sistema jurídico dotando-o de validade a partir de seus preceitos fundantes. A validade desta norma fundamental encontra-se em sua efetiva força normativa e eficácia

\footnotetext{
${ }^{45}$ ALEXY, Robert. Conceito e validade do direito. Tradução: Gercélia Batista de Oliveira Mendes. São Paulo: Editora WMF Martins Fontes, 2009, p.17 e ss.

${ }^{46}$ ALEXY, Robert, op.cit., p.113 e ss.

${ }^{47}$ KELSEN, Hans. Teoria Pura do Direito. São Paulo: Martins Fontes, 7ed., 2009, passim.
} 
social vinculada à sua abstração máxima, já que, não haveria mais norma acima desta. Aqui adentra-se na transição que Kelsen vai abordar entre o ser para o dever ser. O ser aqui constitui-se na legalidade efetiva na eficácia social da constituição. O dever é em curtas palavras, a validade jurídica da norma fundamental - a constituição- de onde emana toda a gama de preceitos que devem se conformar à norma fundante, sob pena de serem inválidos.

Para Kelsen, esta norma fundamental é completamente neutra quanto o seu conteúdo, logo na visão por ele ditada, não se afirmaria um valor transcendente ao ordenamento positivado.

Em Hart ${ }^{48}$ há uma grande crítica à necessidade de uma norma legitimadora daquilo que Kelsen chamou de norma fundamental. Para ele não haveria necessidade de uma norma fundamental, mas sim de uma regra de recognição, como ele mesmo denominou, também entendida como uma regra de reconhecimento, sem negar que nalguns pontos sua concepção assemelhar-se-ia à de Kelsen.

Justamente no pensamento de Hart, que apenas ilustramos, a regra de recognição é regra máxima do sistema jurídico. Nessa qualidade pressupõe todas as fontes de validação para todo o ordenamento. Mas, ao mesmo tempo em que se assemelha ao pensamento kantiano, em sua obra Hart deixa claro:

A norma de reconhecimento só existe como uma prática complexa,
embora normalmente convergente, que envolve a identificação do
direito pelos tribunais, autoridades e indivíduos privados por meio da
referência a determinados critérios. Sua existência é uma questão de
fato. ${ }^{49}$

${ }^{48}$ HART, H.L.A. $O$ conceito de direito. São Paulo: WMF Martins Fontes, 2009, 245 e ss.

${ }^{49}$ Op.cit., p.107. 
Talvez, no entendimento deste autor, só se poderia falar da existência sem se discutir a validade da regra de reconhecimento (rule of recognition). Ora, sob este viés esta regra não só validaria todo sistema como seria também o critério máximo de validade em si mesma e para ela mesma. Hart, deduz a existência da regra de reconhecimento pelo consenso social, pela aceitação o que de fato, apesar de sedutor, não parece se coadunar com um contexto policontexturalidade, devolvendo o raciocínio à norma fundamental kelseniana, com as devidas pontuações e críticas de que não se pode olvidar, mas que não são objeto deste trabalho.

Desta feita então, parece que da evolução do pensamento iluminista, jusnatural e positivista à concepção atual de uma torrente comunicacional, de fato a convergência dos pensamentos em torno de uma congruência racional para construção normativa é inafastável. Em todas as análises a existência de um pensamento fundamental, ora calcado na natureza ou na natureza das coisas, ora calcado em uma norma fundante de todo o sistema, o fato é que no ponto central está a sociedade em constante crescimento e evolução. Não há como negar este fato.

A partir do momento que há uma proposta de construção de uma análise sob a transição do Direito Civil para um Direito Civil-Constitucional, não parece racional desprezar estes pontos de convergência dos pensamentos, mesmo porque, hão de se amalgamar na ideia fulcral de que a própria evolução sistêmica, ainda que em autopoiese, encontra elementos fundantes que na condição de expectativas desviantes, serão ou não absorvidas para a continuidade da evolução.

Nisto se vê claramente, que a fonte retroalimentadora deste processo não é a sociedade sozinha, e tão pouco o sistema jurídico sozinho, mas uma conjugação de sistemas que permeando-se vão determinando em prol da estabilização de valores congruentes, a estruturação do sistema social. 
Assim, nesta parte inicial, optamos pela análise racional que se aloja num pensamento tópico-sistemático. Mas, pela própria posição da sociedade em sua escala evolutiva, neste cenário de grande complexidade, que alavanca indubitavelmente o Direito Civil para esta quadra do tempo em consonância com os valores prospectados no seio do sistema constitucional, ao que nos parece a tópica ocupa um lugar próprio na solução do problema concreto a partir da construção de premissas que silogisticamente vão buscar adequar a justiça no problema apresentado, logo, num plano inferior ou talvez, interno ao processo final de adequação da norma ao caso.

Mas, num plano superior, "em cima" reside a transversalidade das relações sistêmicas tanto entre o sistema jurídico e o sistema social, como também, entre os sistemas parciais do Direito Civil e Constitucional. Por isso mesmo, diante de horizontes que se abrem numa policontexturalidade, em sociedade fragmentada e cada vez mais complexa é que talvez, mesmo que perfunctoriamente nos socorramos ao longo do raciocínio de elementos da teoria Luhmaniana a fim de demonstrar o fenômeno. Mas ainda fica uma última questão para discussão nesta primeira parte: Qual a posição do Direito Civil no cenário analisado?

\subsection{Direito Civil na policontexturalidade e diferenciação funcional de sistemas: da problemática da dicotomia público e privado ao momento atual}

Admitindo a atuação do sistema econômico, mesmo que indiretamente, sobre a evolução social e jurídica, de fato existe um movimento indubitavelmente sedimentado de transferência de relações em diversos níveis, inclusive o contratual, para a esfera privada, retirando da atuação e intervenção pública, papéis que eram seus na atuação do seio social. 
O papel do Direito Civil, aqui tido como norma de direito privado, ultrapassa a dicotomia público/privado, para realizar o social além dos termos meramente regulatórios patrimonialísticos, familiaristas ou sucessórios e se coloca num novo papel de concretizador de normas substanciais fundadas em preceitos de direitos humanos e fundamentais. Não há dúvidas, portanto, que o Direito Civil, como manual egoístico de regras quase solares no sistema jurídico, deixou de existir. Mas, não há como negar que sempre houve uma crise estampada na dicotomia desta summa divisio.

Talvez a primeira crise que se apresente se dê no plano metodológico conceitual, dadas as suas incompletude e grandiosa tendência a críticas. Mas, não apenas isso. Para alguns autores, como Assagra ${ }^{50}$ tais crises de relacionamento entre Direito Público e Direito Privado são decorrências dos avanços de novas categorias de direitos fundamentais no transcorrer dos últimos tempos. Enquanto no paradigma do Estado Liberal o que ocorria era a manutenção de um sistema de direitos voltados ao Estado, a dimensão dos indivíduos era regulamentada pelo Direito Privado que por sua vez respondia bem aos anseios de uma sociedade assim dita burguesa e dominante.

Outrossim, com o surgimento dos direitos chamados de segunda dimensão, principalmente os direitos sociais, a crise de divisão clássica se tornou evidente, onde os direitos fundamentais ressaltaram-se em plano superior aos interesses do antigo Estado, para dimensionarem-se em todos os espectros do sistema jurídico, inclusive, o direito privado. O Estado Social do Direito emerge como um estado neutro com uma concepção normativista e dirigente a partir de um preceito fundamental de uma norma fundante, ás voltas sempre com as constantes investidas do sistema econômico visando sempre a controlabilidade da política e da sociedade.

\footnotetext{
${ }^{50}$ ALMEIDA, Gregório Assagra de. Direito material coletivo: superação da summa divisio direito público e direito privado por uma nova summa divisio constitucionalizada. Belo Horizonte: Del Rey, 2008, p.411 e ss
} 
Numa brutal sintetização do que foi esse caminhar, pode-se dizer que esta crise entre o público e o privado se acentua com o surgimento dos direitos fundamentais de terceira e quarta dimensões, próprios do novo paradigma de Estado Democrático de Direitos que se vive nesta quadra de tempo. Muitos destes relacionados com a solidariedade coletiva que denotam um novo quadro onde o Estado passa a atuar com ênfase no coletivo, o que de forma alguma é visto como uma massa abstrata, mas partindo do indivíduo, do sujeito em primeiro plano, para determina-lo num contexto socializado.

A teoria dos direitos fundamentais impõe ao Estado o dever de proteção e efetivação de uma série de direitos nucleares, que irradiando do sistema constitucional vinculam toda a ordem jurídica. Sob essa nova realidade resta sufocada a summa divisio padecendo de ser superada do paradigma fechado que lhe originou.

Numa nova ordem onde direitos de dimensão avançada tomam o cenário jurídico, desconsiderar a ressignificação do homem como centro dessas transformações, mesmo que as analisando por um prisma apartado "de cima", de forma alguma afasta do Direito Privado seu escopo principal que é o de regular a vida privada, assim como, as repercussões das inter-relações humanas nas mais diversas categorias de relações jurídicas.

O exercício das liberdades sem a interferência ilegítima por parte do estado ou de outros particulares, aqui em nosso trabalho, no tocante ao exercício da própria autonomia privada, a manutenção do mínimo existencial e do bem-estar social são exemplos corriqueiros dos avanços no campo do Direito Público, mas sem dúvida, irradiam-se para vincular o Direito Privado na realização dos mesmos escopos.

Em Teubner ${ }^{51}$ a ideia de uma distinção na dimensão desta summa divisio sinaliza uma diminuição do problema à luz de uma departamentalização do direito, o que

\footnotetext{
${ }^{51}$ TEUBNER, Gunther. Direito, Sistema e Policontexturalidade. $1^{\circ}$. ed. Piracicaba: EDITORA UNIMEP, 2005, passim
} 
por consequência implica numa inadmissível simplificação da compreensão da própria estrutura social moderna. Todavia, ao contrário, propõe a partir da ótica da teoria dos sistemas uma compreensão adequada do fim da dicotomia público/privado dentro da noção de policontexturalidade.

Como já delineado acima esta acepção parte da grande complexidade que a sociedade assumiu. E disso não há dúvida quando se observa que da sociedade em evolução e diferenciação, o sistema jurídico emerge como um dínamo gerador de preceitos prospectivos e calcados em expectativas congruentes com valores comungados no seio do contexto social a partir de um compromisso de realização de tais axiomas sedimentados em bases principiológicas inafastáveis da norma fundamental ${ }^{52}$. É verdadeira ponte que vai se formar entre dois sistemas parciais, a saber, Direito Civil e Direito Constitucional, para que a partir deste último aquele possa prospectivamente realizar substancialmente suas normas em adequação com as exigências da sociedade moderna.

E ao se conceber este pensamento arquitetado numa ponte, sem querer ser simplista, leva inexoravelmente à crença de que a tal se assenta sobre pináculos que por sua vez são erigidos pelos processos de variação, seleção e restabilização, que Teubner apesar de não os conceber em sua obra, claramente, assume concepção favorável ao ideal Luhmaniano quando ressalta a existência de uma multiplicidade de alternativas (análogas às variações) que são em si processos de diferenciação. Inclusive, sob esta perspectiva aquele $^{53}$ admite a pluralidade de setores no sistema social que sequer encontram pressuposto e validade na racionalidade estatal, política ou econômica ${ }^{54}$. Logo, existem

\footnotetext{
${ }^{52}$ PERLINGIERI, Pietro. Perfis do direito civil. Introdução ao direito Direito Civil Constitucional. Tradução: Maria Crisctina Cicco. 3.ed. Rio de Janeiro: RENOVAR, 1997, p.54 e ss

${ }^{53}$ TEUBNER, idem ibidem

${ }^{54}$ Em ensaio de leitura primordial, Teubner trata de sua Bukowina Global e o pluralismo jurídico em ordem jurídica internacional. Resta claro neste texto que a partir de um diagnóstico de Luhmann o autor desenvolve um poderoso argumento que em que os processos de comunicação e autorreprodução sistêmica são
} 
relações nascentes e já estabelecidas que fogem a esta dicotomia deslizante entre público e privado.

Esse quadro já remonta os últimos anos dos Oitocentos e na esteira de resgate histórico montado em primoroso texto por Cristiano Paixão ${ }^{55}$, quando aponta para a série de transformações ocorridas neste período que, como já ressaltamos aqui, enfraqueceram primariamente o jusnaturalismo racional que perde, na visão deste autor, a sua capacidade de explicação e fundamentação do Direito.

O aumento da complexidade no sistema social, as revoluções principalmente a industrial- e o incremento da modernidade impulsionada por um conceito reflexivo de abertura para o futuro, para o progresso, juntamente com a introdução do constitucionalismo, definem o período.

Anteriormente, o século XVIII concebia duas aquisições evolutivas para a sociedade: a diferenciação funcional e o surgimento das constituições escritas, conforme

deslocados dos Estados. Não é nosso intuito aproveitar este argumento como fundamento de uma ordem constitucional civil fora do Estado. Mas, nos socorre a ótica do pluralismo acentuado como marca de nosso tempo. Ao tratar da Lex Mercatoria, o grande professor ressalta ser o exemplo mais exitoso de formação de um ordenamento transnacional sem qualquer vinculação, mesmo para sua criação, do Estado como ente capaz de praticar a atividade legiferante. Forma-se assim um ordenamento, que muitos ousaram chamar de constituições civis, quando na verdade seria um ordenamento em si, acoplado a processos sociais e econômicos e não a uma realidade estatal. Sua construção por esses acoplamentos estruturais na suspeita que o autor levanta, levará este ordenamento transnacional a uma repolitização, guiado por axiomas de uma sociedade cada vez mais plural e especializada. E esposado em tal pensamento, continua Teubner, a interpretação desse direito global só pode correr mediante uma teoria do pluralismo jurídico e uma teoria das fontes do direito, respectivamente concebida nos mesmos termos pluralistas. E ao tratar das Global Villages, ainda acentua: "Disso resulta a nossa tese principal: o direito mundial desenvolve-se a partir das periferias sociais, a partir das zonas de contato com outros sistemas sociais, e não no centro de instituições de Estados- nações ou de instituições internacionais. As global villages de áreas sociais parciais autônomas formam a nova Bukowina da sociedade mundial, na qual o direito vivo, de Eugen Ehrlich, ressurge nos nossos tempos. Aqui se localiza a razão mais profunda do fato de que nem as teorias políticas nem as teorias institucionais do direito, mas tão somente uma teoria - renovada - do pluralismo jurídico, pode fornecer explicações adequadas da globalização do direito." (TEUBNER, Gunther. The Global Bukowina on the Emergence of a Transnational Legal Pluralism. In: IMPULSO, Piracicaba, v. 14, n. 33, p. 1-191, jan./abr. 2003)

${ }^{55}$ PAIXÃO, Cristiano. Arqueologia de uma Distinção: o Público e o Privado na Experiência Histórica do Direito. In: O novo direito administrativo brasileiro, o Estado, as agências e o terceiro setor. Cláudia Fernanda de Oliveira Pereira (org). Belo Horizonte: Fórum, 2003, p.19-51 
continua preceituando o autor citado que se baseia na teoria luhmaniana para explicar os processos de diferenciação social que vão definir este período.

Essa diferenciação funcional, já destacada como um dos motes da modificação da própria estrutura do Direito Civil, reestruturou e reestrutura a sociedade em sistemas funcionalmente especializados, o que exige a simultaneidade de existência entre vários subsistemas numa sociedade descentrada. Sob este viés o Direito então compartimentado, começa a esvanecer diante da necessidade de uma reformulação de suas cadeias normativas, no Brasil influenciadas por um positivismo engessado já a partir do século XIX a par da experiência moderna do novo Estado Liberal.

O direito público como um conjunto normativo estatal passa a ser visto como dissonante com a realidade de um Estado que tem por obrigação estruturar-se de modo a evitar o retorno ao absolutismo, ${ }^{56}$ assim como, a implementação de uma série de direitos que permite o empoderamento da sociedade com normas públicas garantidoras de direitos fundamentais e humanos.

O direito privado, neste quadro histórico é superdimensionado para o resguardo e emancipação do indivíduo. A autonomia privada ganha no contexto contratual um incremento, por sua potencialidade na realização das relações jurídicas negociais entre os sujeitos de direito, autônomos e imantados por uma série de normas protetivas lastreadas no seio de códigos de regras privadas, a exemplo do Código Civil.

Com a ruptura do paradigma liberal já na segunda metade do século XIX e sua formatação na distribuição desigual do poder e da riqueza, a reação do Estado é a mudança desse paradigma para um Estado Social que passa a integrar no rol das constituições uma série de direitos sociais e estruturas constitucionais de reconhecimento

\footnotetext{
${ }^{56}$ NETTO, Carvalho. Menelick de. A hermenêtica constitucional e os desafios postos aos direitos fundamentais. Jurisdição constitucional e os direitos fundamentais. Belo Horizonte: Del Rey, 2003, p. $141-163$
} 
dos sujeitos de direito, tanto no plano individual, quanto coletivo formando um núcleo duro de normas limitadoras em todos os campos, como consumerista, trabalhista e econômico. Nesta quadra da história ocorre profunda modificação da relação entre público que passa a padecer de uma hipertrofia, quanto do privado que passa por um processo de mudança de paradigmas deixando de ser uma norma voltada para egoísmos anteriores à vida em sociedade.

Como se vê, neste contexto de complexificação social, já há claramente um processo de diferenciação funcional, onde o que se vê é uma guinada do próprio processo construtivo do Direito Civil que agora vê como imprescindível ao fundamento de unidade do ordenamento jurídico o respeito a vetores inarredáveis consagrados no sistema constitucional, sendo o mais determinante de todos a dignidade da pessoa humana ${ }^{57}$.

Emergiu deste processo pelo qual o direito privado veio passando, uma nova sistemática voltada para uma convergência com a pluralidade de alternativas, expectativas desviantes dentro do sistema político, social e no sistema constitucional, onde aquele assumiu um papel de conceptor e refletor, nesta lógica interna, do resultado da restabilização, ocorrida em face do processo comunicacional e o acoplamento com os demais sistemas, sempre com a face voltada à implementação das expectativas congruentes e atreladas ao sistema constitucional.

\footnotetext{
${ }^{57}$ PERLINGIERI, op.cit. p.55. E aqui entendemos como sendo uma contingência da própria ciência jurídica este atrelamento rumo à unificação dos sistemas tendo a constituição como fonte maior do direito, como fonte do Direito Civil. Cf. HESSE, Konrad. Derecho constitucional y derecho privado. Trad. Ignácio Gutiérrez G. Madri: Civitas, 1995, passim. Para outros juristas importantes como Judith Martins-Costa, as relações entre a Constituição e o Direito Privado, se concebem pela relevância dada aos processos hermenêuticos das normas constitucionais, como ocorrem com as chamadas cláusulas gerais no Código Civi, contudo, pelo entendimento dado pela autora, num plano hierárquico, com que, já repisamos somos obrigados a divergir, mesmo entendendo haver desníveis entre os sistemas e seus ambientes. Mas, seja como for, elementos com a boa-fé calcada na moral - objetiva- a função social dos contratos e da propriedade, são exemplos desta conjunção das normas constitucionais em âmbito privado (HESSEDrittwirkung). (MARTINS-COSTA, Judith. As cláusulas gerais no projeto do Código Civil brasileiro. In: Revista da Faculdade de Direito da UFRGS, vl.15. Porto Alegre: Síntese, 1998, p.140 e ss
} 
Considerando essas operações de comunicação no contexto atual o direito privado assume a responsabilidade de reformular-se, guindando conceitos como da propriedade privada e da autonomia privada pelos contratos à mesma conjuntura desta sociedade plurifacetada, onde a dimensão do sujeito autônomo e dotado de liberdade, direitos e garantias fundamentais e de autonomia da vontade trafega por essa complexidade social, cujas cercanias na vida privada agora exigem uma norma civil calcada em preceitos substanciais, a saber, normas evolutivas lastreadas por paradigmas restabilizados no sistema jurídico, mormente, no constitucional.

Neste viés, o Direito Civil se comuta em instrumento com cabedal suficiente à adequação entre as esferas autônomas da sociedade fragmentária e especializada e seu cerne passa a ser a construção de normas jurídicas plurais tal qual é a sociedade, o que pode implicar num processo de construção que perpasse pela hermenêutica, tanto a nível teleológico como sistemático, com guisa sempre à adequação, capacidade e resistência das expectativas estabilizadas no sistema civil.

Buscando contextualizar o direito privado neste terreno de sociedade complexa, Teubner ${ }^{58}$ acentua que sempre houve uma tentativa de desvincular o direito privado da noção de normatização do sistema econômico, que este autor ressalta como sendo o mais tendencioso a colonização plena dos demais sistemas. Isso se torna realçado quando se observa, mormente no período hodierno, que o direito contratual assumiu importante papel principalmente no campo dos interesses de corporações empresarias e a autonomia privada assumiu um papel de relevância sem precedentes. A propriedade por sua vez, alçou caminhos de pluralidade tal qual a exigência do atual cenário, sendo guiada pelo princípio de sua função social a um patamar de função social plúrima, já que, a própria sociedade assim o é. A grande questão, ressaltada por Teubner, é que esse

\footnotetext{
${ }^{58}$ Op.Cit. passim
} 
processo de desvinculação dificilmente teria sido impedido, porque não se pode esquecer que o sistema social sofreu e sofre colonização pelo sistema econômico e o político, muito mais no regime capitalista de mercado.

E justamente por essa questão a autonomia privada, tão enaltecida como cerne do direito privado atual passa a ser plural, ou seja, fala-se em autonomias privadas no contexto de uma sociedade policontexturalizada. Aí que o direito privado assume o desafio do equilíbrio em face dos sistemas que buscam colonizar o sistema social e o apoio maior é buscado no sistema constitucional que passa a ser o mote na construção de normas espontâneas e auto regulamentadoras de setores sociais específicos, segundo suas especificidades.

Ainda no pensamento deste grande autor, os critérios de regulamentação da norma em direito privado devem ser concebidos com base numa reflexão descentralizada em oposição à mera e constante reflexão com base exclusiva no sistema político, que é o que ocorre atualmente.

A racionalidade do direito privado atual pode e deve contribuir para possibilitar uma reflexão dinâmica, prospectiva e substancial com horizonte voltado para o equilíbrio entre as tensões dos sistemas social e econômico, sempre mantendo como fiel da balança a preservação dos preceitos estabilizados a partir do processo comunicacional em face do sistema constitucional.

Ao exemplificar a questão pode-se citar exemplos que vão ao encontro dessa racionalidade como ocorre com a modernização do direito de família coadunado com as novas tendências de pluralização da família; a proteção jurídica do consumidor; as novas concepções dos direitos reais com as atuais conceituações da posse em sentido democrático ou as tipologias de propriedade; as modalidades de usucapião baseada em normas constitucionais com sua função social, mormente a preservação da dignidade da 
pessoa humana tal qual ocorre em normas internas como o Estatuto das Cidades (Lei 10257/01), a modificação do estatuto da pessoa portadora de necessidades especiais, que alterou o Código Civil brasileiro recentemente (lei 13.146/2015) e outros que infelizmente deixa-se de citar até porque não é escopo deste trabalho volver a análise sobre esses preceitos normativos em específico.

De fato, o direito privado no atual contexto, se não pode perder sua capacidade de construção de premissas (topoi) para solução de problemas que se colocam nos casos concretos no seio das relações privadas, também não pode olvidar seu papel de instrumento que tange suas cordas para estabelecer dentro dos processos de comunicação com os sistemas político e econômico, normas que fortaleçam e conduzam a sociedade plural além da mera adequação a contextos políticos e/ou econômicos.

Sob essa mesma esteira fica claro o papel do direito privado de defender as esferas da sociedade, assim como, a autonomia volitiva dos agentes na realização de escopos que emergem das relações privadas no contexto social.

Outrossim, no que tange ao objeto discutido por Teubner ${ }^{59}$, seria da alçada do direito privado criar normas baseadas em irritações não captadas estritamente do sistema econômico, cuja tendência seria a de exercer influência totalizante sobre o sistema social. Aqui a melhor explicação para esta concepção reside no objetivo do direito privado em criar elementos normativos de limitação, com guisa à resistência e capacidade da expectativa restabilizada, como é o exemplo do direito do consumidor, lastreados em processo de comunicação heterárquica com o sistema constitucional, em princípios objetivos de blindagem da pessoa humana, espargidos sobre um microssistema normativo, que neste exemplo é o Código de Defesa do Consumidor atual.

\footnotetext{
${ }^{59}$ TEUBNER, Op.cit passim
} 
Ainda assim, neste caminhar desenvolvido pelo direito privado Fachin ${ }^{60}$ levanta importante crítica a respeito da construção de uma racionalidade baseada numa pretensa constitucionalização do Direito Civil, calcado em opinião no sentido de que não se trata apenas de uma crítica quanto a construção do conceito, mas também quanto a própria estrutura do Direito Civil, que dotado de autonomia principiológica, normativa e conceitual, pode incorrer em incompatibilidade quanto a sua estrutura patrimonialista e abstracionista encerrada no seio do atual Código Civil e a esperada congruência com a racionalidade constitucional, mormente quanto aos ditames protetivos da pessoa humana.

E mais uma vez volta ao cenário a crítica à racionalidade codificadora que permeia o Código Civil atual, que em várias passagens estatui preceitos que podem determinar processos de exclusão de expectativas selecionadas nos processos de variação na comunicação com o sistema constitucional, o que entre nós pode encerrar ofensa a direitos fundamentais, principalmente se considerarmos a mera aplicação de em caso concreto da solução ofertada pela letra fria da lei, ou com pontos de vista (premissas) ancoradas única e exclusivamente na racionalidade civilística o que fatalmente impedirá o reconhecimento de preceitos fundamentais e humanos, cujas bases normativas e os princípios jazem no contexto constitucional.

É um dos modos pelos quais o próprio Direito pode provocar vítimas, afastando-se de uma direção emancipatória. São as exclusões que ainda marcam o final do século XIX, perduraram no século pretérito, e vincam a racionalidade codificadora na atualidade. $^{61}$

Na problematização da tópica para solução de conflitos, a subsunção à norma constitucional, especialmente quanto aos direitos fundamentais, não é de forma alguma

${ }^{60}$ FACHIN, Op.cit. p. 51 e ss.

${ }^{61}$ FACHIN, idem ibidem. 
resposta adequada frente à resistência do sistema codificado. O modelo da codificação aqui nada mais é senão uma constituição em si mesmo, isto é, uma norma pretensa a ser fundante, sem o ser, em cujas regras estaria a resposta para a totalidade dos preceitos e relações privadas. E o grande problema é que mesmo agora, nesse exato momento em que se elabora o presente texto, o Código resiste enquanto instrumento de formulação e problematização do homem privado.

Entretanto, mesmo diante de tal crítica, não é despiciendo enfatizar que o Direito Civil caminha na mesma direção do sistema constitucional, porque apesar de sua sólida estruturação em bases principiológicas e normativas, nalgumas vezes enraizadas em preceitos romanistas vetustos sem muitas modificações, algo que jamais pode ser olvidado é que como ramo voltado à tutela das relações privadas, o Direito Civil não pode a pretexto de se tornar obsoleto, desconsiderar por completo a própria evolução do sistema social.

E se considerar-se que esta evolução na atualidade contextualiza a norma privada numa sociedade diferenciada a nível mundial, coletivizada quanto ao elemento de cidadania e dotada de normas fundamentais que a cercam, pode se dizer numa visão habermasiana que em um ordenamento jurídico, principalmente voltado para uma reconstrução da norma privada, tais transições preservam “como todas as ordens jurídicas modernas, um caráter estritamente individualista: ela se baseia em última instância nos direitos subjetivos dos cidadãos" ${ }^{2}$

E, em tal idealização, o reconhecimento recíproco das ordens da consciência ${ }^{63}$ do indivíduo singular em face de outrem na construção da identidade e do

\footnotetext{
${ }^{62}$ HABERMAS, Jürgen. Sobre a constituição da Europa. Tradução: Denilson Luis Werle, Luiz Repa e Rúrion Melo. São Paulo: ed. UNESP, 2012, p. 72.

${ }^{63}$ SANTOS, José Henrique. Trabalho e riqueza na fenomenologia do espírito de Hegel. São Paulo:Loyola, 1993, p.83 e ss.
} 
reconhecimento, tangencia uma das facetas das quais a norma privada não pode desconsiderar no seu atual contexto: a igualdade substancial.

Neste cenário o Direito Civil transcende a própria particularização dos sujeitos, para primar pela construção de uma norma dotada de cláusulas gerais, a saber, regras que visem sob a batuta de preceitos fundamentais, manter entre os sujeitos numa relação jurídica privada a igualdade segundo suas condições jurídicas, e o equilíbrio da própria relação.

Exemplos claros disso encontram-se nas novas formulações da teoria contratual enfatizando a moral na boa-fé, a aplicação da cláusula rebus sic stantibus em face do caráter existencial da pessoa humana, a igualdade e o equilíbrio das relações contratuais, a igualdade nas relações conjugais com respeito à diversidade de famílias, a evicção, limitação da cláusula penal, a proteção do consumidor, as usucapiões coletivas embasadas na função social da propriedade e etc.

Destarte, se pode perceber a importância do problema metodológico estudado neste capítulo pelo estudo da tópica e da teoria dos sistemas em Luhmann, justificandose sua inclusão neste trabalho porque se de um lado tem-se presenciado um avanço contínuo da evolução do sistema constitucional abarcante em constante comunicação com ordens jurídicas diversas, em face do sistema social mundial em esfera transconstitucional ${ }^{64}$, com relações transversas diante dos significativos problemas de ordem internacional e convergência de valores e princípios; de outro lado, não se pode olvidar que em nível interno a estabilização dessa comunicação irradiará para todo o

\footnotetext{
${ }^{64}$ Expressão cunhada na obra de Marcelo Neves tratando do entrelaçamento entre Constituições Civis na sociedade mundial onde o autor concentra-se em determinar os níveis deste entrelaçamento não só entre ordens jurídicas, mas na construção de uma racionalidade transversal mediante a troca e o intercâmbio de valores, preceitos normativos entre ordens jurídicas diversas. E aqui é preciso explicar que o único motivo para se levantar este conceito é justamente para esclarecer que mesmo antes dos processos internos de comunicação entre o sistema constitucional brasileiro e o Direito Civil pátrio, a nossa ordem jurídica já mantem em nível ainda mais abstrato e superior essa troca transversa entre sistemas constitucionais e sociais mundiais. (NEVES, Marcelo. Transconstitucionalismo. São Paulo: Editora WMF Martins Fontes, 2009 , p. 115 e ss)
} 
ordenamento, mormente o Direito Civil, todos os comportamentos e expectativas congruentes internalizados pelo sistema.

O Direito Civil será parte e participativo nesse processo dialógico com o sistema constitucional, mas na direção dos problemas e casos concretos que se apresentarão e a tópica exercerá o papel integrador do sistema civil na construção das premissas hermenêuticas, voltadas à busca da justiça e equidade no caso concreto por via da aplicação de suas regras, porém, norteada pela constante influência do sistema constitucional que permeando as normas civis, acaba ultrapassando a própria fronteira entre público e privado, para imperativamente determinar uma releitura e porque não uma reconstrução do Direito Civil e seus primados para, adequá-los ao momento constitucional atual desta era da solidariedade e principalmente, determinar a absorção de direitos fundamentais e da dignidade como fonte moral para criação de normas e regras de toda ordem.

Assim, se considerar-se a teoria dos sistemas como modelo analítico para demonstrar esses níveis de comunicação em substrato muito mais elevado, ainda assim o uso da tópica se fará necessário para implementar nos casos concretos as regras de Direito Civil agora inserido nessa nova ordem civil-constitucional que pouco a pouco vem se sedimentando no ordenamento.

Por fim, diante dessa contextualização do Direito Civil e seu papel neste universo de comunicações crescentes, a tarefa agora se volta para o reconhecimento do sujeito neste processo, a fim de se avançar na análise quanto às questões relacionadas à preservação de sua dignidade, lendo este conceito como um metaprincípio fomentador dos direitos fundamentais, em que pese, concordarmos com a existência de vários outros pontos de toque entre o Direito Civil e o Direito Constitucional, como é o caso da função social, que não é alvo deste trabalho, mas é citada apenas como uma ilustração. 


\section{A REALIZAÇÃO DE UM DIREITO CIVIL CONSTITUCIONAL A PARTIR DA DIMENSÃO DO "SER HUMANO"}

\subsection{Pela construção de um sujeito de direitos a partir da conceituação desde a pessoa humana e sua posição enquanto sujeito de direitos}

Importante determinar aqui a posição adotada neste pensamento a partir da pessoa enquanto sujeito de direitos, eis que a maioria das relações interpessoais em matéria de relações privadas - numa breve ilustração- e mesmo a proteção de atos jurídicos em sentido estrito, partem da concepção ora da autonomia privada, ora da função social, ora da eticidade que tais relações devem exercer.

Estas por sua vez são dimensões das vontades manifestadas segundo os sujeitos envolvidos, porque não há que se falar na formação de uma relação de direito real minimamente distanciada de uma autonomia privada antecedente (relação pessoal), seja pela aquisição originária (normativa), seja pela aquisição derivativa (negócios jurídicos antecedentes).

Então, não há que se falar no desenvolvimento de relações olvidando que seus agentes antes de serem mero constructo abstrato determinado pela norma, são pessoas que demonstram suas personalidades e capacidades como atributos inderrogáveis que são reflexivos tanto em seara puramente privada, quanto em sua inserção no universo social.

Assim, mesmo considerando qualquer análise superior - de cima- para determinar o processo de comunicação do direito privado em uma racionalidade calcada na substancialidade constitucional, logo em campo puramente normativo, ainda assim é preciso compreender que na base está o sujeito não como um objeto, mas antes como um ser movido por uma consciência dotada do poder necessário para o desenvolvimento de 
uma autodeterminação que passa ao longe do ideal cartesiano de unidade do ser em si mesmo, mas parte abrindo espaço para a consciência de si a partir de uma diáspora do próprio eu e da certeza de si para uma operação de identificação de dupla jornada de exteriorização e interiorização deste eu, para em processo de negação de si e de seu conteúdo, encontrar no outro a diferença que se tornará em identidade a partir do reconhecimento e não da reificação deste outro como se objeto fosse.

Fala-se aqui de plúrimas personalidades, cujos espíritos livres são capazes da construção de normas entre si e para si, o que sobrelevado ao patamar dos grupos sociais exaure-se na formação de normas regulatórias dos interesses destes grupos segundo comportamentos, valores e aspectos até mesmo culturais dos quais não se tem como fugir.

Abandonando o solipsismo da certeza de si, o sujeito se constrói a partir da liberdade e da independência de se reconhecer no outro (eu negativo) de forma que culmine num processo dialético e independente que é de total importância para os fins normativos do Direito Civil.

E esta exigência da construção da consciência de acordo com a lógica da reciprocidade hegeliana ${ }^{65}$ e sua fenomenologia do espírito, determina-se por este movimento de exteriorização do conhecimento e reconhecimento rigorosamente independente e simétrico entre os sujeitos. E esse impulso, no que se pôde entender dáse pela dialética que em última instância, prima por uma igualdade não apenas formal mas substancial sem olvidar ainda do cultivo de valores, da formação de relações jurídicas de caráter factual e contratual em todos os níveis, que servem em sua totalidade conceitual como instrumentos de exteriorização do encontro de duas vontades em relações que até podem ser obrigacionais, patrimoniais ou inseridas no núcleo das relações familiares que em si constituir-se-ão em normas entre as partes, dirigidas por preceitos maiores que não

\footnotetext{
${ }^{65}$ SANTOS, José Henrique. op.cit. p.27 e ss
} 
se encerram apenas no contexto do códex ou mesmo de suas vontades livres e conscientes, mas antes vão sedimentando-se no seio social pelo lastro que firmam com normas fundamentais e humanas emanadas do sistema constitucional numa dimensão solidária, sem dúvida.

Para mais do que isso a essência deste sujeito é de toda importância para designar os fins buscados pelo Direito Civil, enquanto um sistema normativo agora permeado por normas constitucionais que promovem um dirigismo de seus elementos voltando-os para a realidade social implementada e resultante de seu processo evolutivo, retirando do centro das discussões a mera construção de normas civis que busquem antever fenômenos relacionados às relações privadas em núcleo fechado meramente em contexto patrimonial, familiarista ou sucessório, mas para além, busque condicionar a pessoa humana a uma gama protetiva que é nada mais nada menos do que a manifestação do caráter substancial do Direito Civil Constitucional.

Então, fala-se aqui da pessoa não só como mera destinatária da comunicação oriunda de toda a conjuntura que resultará da autopoiese de sistemas acoplados, conforme citamos aqui para definir o papel da Constituição e o Direito Civil enquanto sistemas internos ao sistema jurídico. Vai-se em singela descrição ao centro formador do próprio vínculo interpessoal ou normativo que é a pessoa.

No final é ela o fim em si mesma e consequentemente a destinatária da aplicação dos direitos fundamentais, das normas constitucionais e infraconstitucionais que decorrem do sistema jurídico que coerentemente e congruentemente vai construindose conforme esta transição se acentua. Claro que, aqui, não há como se negar a constante influência e até tentativa de colonização do sistema econômico, mas o papel limitador do direito em prol de uma equidade lastreada por um princípio de solidariedade não pode ser refutado, pois é a partir dele que a busca pelo equilíbrio substancial das relações ocorre. 
E certamente a noção da pessoa como subjetividade, isto é, dotada de valores em si mesma, capaz de reconhecer no outro a própria consciência, gerando a noção de comunhão não é um conceito novo, como se vê nos escritos de Santo Agostinho ${ }^{66}$ quando na construção da imagem de Deus e a Trindade demonstra o ser como um ente que encontra em si o autoconhecimento como demonstração e prova de sua existência no mundo real a partir da fé em um Deus uno.

Neste pensamento a existência do ser para longe da existência das demais criaturas se dá pela manifestação de uma consciência que ainda enganosa nalgumas pretensões mesmo assim é a prova de sua semelhança com o Criador na visão do santo Padre, e mais, é a prova de sua posição no mundo da realidade, material, sendo capaz de transformá-lo por suas ações e por sua vontade.

Em Hobbes ${ }^{67}$ fugindo de sua análise do contrato entre a sociedade civil e o Estado, na conceituação de pessoa este importante autor a define por seu valor no contexto social e sua capacidade de ser e obter o poder, o valor e a dignidade a partir daquilo que ele considerou ser o poder integrativo de vários homens unidos em consenso cada um no exercício de um papel definidor de seu status no seio social, o que de fato não deixa de ser um resquício do pensamento medieval. Assim, “o valor ou conceito de um homem é, como para todas as outras coisas, seu preço; isto é, depende de quanto seria dado pelo uso de seu poder".

Ainda na esteira do grande pensador referindo-se à dignidade da pessoa, este a colocou como o valor conferido à pessoa pelo Estado, ou seja, pelo poder capaz de exercer e influenciar o seio da sociedade em que vive. Para longe de se dar azo a esta construção como um fundamento do que se está a edificar no pensamento racional deste

\footnotetext{
${ }^{66}$ AgOSTINHO, Santo. A cidade de Deus (De civitate Dei). Int: Padre Riolando Azzi. Tradução: Oscar Paes Leme. São Paulo: EDAMERIS, s/d, p.137 e ss

${ }^{67}$ HOBBES, Thomas. Leviatã ou matéria, forma e poder de um Estado Eclesiástico e Civil. (orig. 1651). Tradução: Rosina D’Angina. 1.ed. São Paulo: Martin Claret, 2014, passim.
} 
trabalho, não se pode negar que em o Leviatã, apesar da colocação peculiar à época em que foi escrito, a essência da pessoa humana estaria no cultivo de valores ligados à honra, à dignidade como atributos inatos, o que é bem verdade para o pensamento da época, mas perseguidos pelos homens, numa clara acepção dos valores humanos como anseios antes para alguns dignatários como descreveria Hobbes em seu homem estatutário, mas que de certa forma jazia como chama acesa na busca da igualdade de tais atributos como valores natos de todas as pessoas. Este momento é o momento atual na era da solidariedade.

Já em Kant ${ }^{68}$ em sua fundamentação da metafísica dos costumes a visão diametralmente oposta ao ideal hobbesiano coloca o ser enquanto pessoa num contexto de moralidade que num impulso do pensamento em sua época não o coliga ao status ocupado no contexto social, mas antes a um atrelamento ao dever contraído pela vivência em sociedade. Na visão deste importante pensador, a vontade deste ser racional não se assenta em sentimentos, mas antes no princípio moral de cumprimento de seus deveres, o que de fato guinda a vontade emanada ao patamar de legisladora de suas ações o que levaria este ser a ser considerado um fim em si mesmo.

Se a razão relaciona a máxima da vontade como legisladora com todas as outras vontades e ações comungadas por outros seres racionais não em virtude de valores solipsistas, então, tem-se a virtude da ideia de dignidade deste ser. Vale a pena aqui fazer citá-lo:

No reino dos fins tudo tem ou um preço ou uma dignidade. Quando uma coisa tem um preço, pode-se pôr em vez dela qualquer outra como equivalente; mas quando uma coisa está acima de todo o preço e, portanto, não permite equivalente, então ela tem dignidade.

$\mathrm{O}$ que se relaciona com as inclinações e necessidades gerais do homem tem um preço venal; aquilo que, mesmo sem pressupor uma necessidade, é conforme um certo gosto, isto é a uma satisfação no jogo livre e sem finalidade das nossas faculdades anímicas, tem um preço de

\footnotetext{
${ }^{68}$ KANT, Immanuel. Fundamentação da Metafísica dos Costumes. Tradução: Paulo Quintela Lisboa/PT:
} Edições 70, LDA, p. 77 e ss 
afeição ou de sentimento (affektionpreis); aquilo porém que constitui a condição só graças à qual qualquer coisa pode ser um fim em si mesma, mas não tem somente um valor relativo, isto é um preço, mas um valor íntimo, isto é dignidade.

Ora a moralidade é a única condição que pode fazer de um ser racional um fim em si mesmo, pois só por ela lhe é possível ser membro legislador no reino dos fins. Portanto a moralidade, e a humanidade enquanto capaz de moralidade, são as únicas coisas que têm dignidade.

Percebe-se deste modo que a formulação kantiana evidencia uma evolução do pensamento jurídico, pois refere o sujeito e não superficialmente o homem em sua pessoalidade. O que se extrai do pensamento deste jusfilósofo é a concepção da conversão do homem em sujeito dotado de uma personalidade juridicamente aferível. Esta racionalidade, deslocada para nossos dias afirma em preceito inarredável o repúdio do tratamento das pessoas como mero objetos ou agentes relegados a serem destinatários do resultado comunicacional, mas antes com um fim em si mesmas.

Ao determinar os domínios do público e privado em verdadeiro rompimento com o paradigma da racionalidade anteriormente criticada, Hannah Arendt ${ }^{69} \mathrm{em}$ primorosa construção estabelece a vida do homem, distinta da natureza humana, na medida em que este homem está enraizado no mundo dos homens que por sua vez é fruto da própria intervenção da atividade humana, ou seja, "vita activa”. Assim, mesmo aqueles homens por mais isolados e distantes de um núcleo social ainda assim dependerão direta ou indiretamente deste mundo dos homens, construído segundo a ação dos mesmos.

Todas essas atividades, são condicionadas pelo fato de que os homens realizam em esfera não abstrata, ou seja, material, ações conjuntas com escopos conjuntos, se pensar-se no fim de todas elas, já que, a conexão que une a todos está imantada pelo caráter do ser social.

\footnotetext{
${ }^{69}$ ARENDT, Hannah. A condição humana. Tradução: Roberto Raposo, revisão técnica: Adriano Correia. 11.ed. 2014, p. 29 e ss
} 
Como explica Arendt ${ }^{70}$, não há ação humana descontinuada ao ponto de sua existência se dar sem uma conexão com outros homens. A tradução e justificação desta ideia remonta a tradução do zoon politikon de Aristóteles, ou a máxima de Tomás de Aquino $^{71}$ homo est naturaliter politicus, id est, socialis o que por sua vez, para além de um conteúdo significante político, indica uma aliança indissociável entre os homens para realizarem um escopo específico que se dá, no que se observa nos dias atuais, pela especialização de tantas atividades e cada vez mais complexas, conforme se aprofunda a complexidade da própria sociedade.

Nesta conjuntura de pensamento a construção da pessoa para um nível de sujeito de direitos, parece ao que se pôde compreender, ter tido seu ponto de partida não da construção ideológica da norma fundamental em torno desta concepção, mas antes da construção do pensamento em torno da função dos homens no contexto social.

O homem é um fim em si mesmo e quando soergue sua capacidade de organização a um nível político não apenas a nível associativo, mas numa posição de oposição direta ao centro natural que é o seio familiar, passa ao nível de seu bios politikos, para existir em duas ordens de existência como quer Arendt: "uma vida entre aquilo que lhe é próprio (idion) e o que é comum (koinon) ".72

Então, nesta visão o sentido do termo social começa a adquirir o sentido da própria condição humana. Aqui, não é escopo deste trabalho investigar a criação da concepção social a partir do aniquilamento das unidades orgânicas de parentesco em prol do comum como viria a deduzir Fustel de Coulanges $^{73}$ em sua obra Cidade Antiga, mas basta ao que se quer demonstrar indicar a ponte que levou o ser atomístico à esfera do ser

\footnotetext{
${ }^{70}$ ARENDET, op.cit., p.30

${ }^{71}$ AQUINO, São Tomás. Suma Teológica. Trad. Aimom-Marie Roguet et al. São Paulo: Loyola 1 ,2001 i.96.4;ii2.109.3.

72 ARENDT, idem, ibidem.

${ }^{73}$ COULANGES, Fustel. A cidade antiga. Tradução: Jean Melville, São Paulo: Martin Claret, 2007, passim.
} 
comunitário, agora apto à manter uma série de relações jurídicas que vão além da esfera meramente privada para o transformar em sujeito de direitos em face de relações cada vez mais complexas quanto mais complexa a própria sociedade vai se tornando. E há uma convicção já pré-formada de que o reconhecimento da personalidade do sujeito como conector de sua existência inderrogável no contexto do mundo é o tom que conduz a melodia.

Platão ${ }^{74}$ em sua obra, apenas volvendo superficialmente o pensamento grego, já dimensionaria a própria constituição do Estado a partir da especialização das atividades dos homens objetivando a construção de um fim comum baseado em aspectos participativos. Ele retira o homem de sua condição natural, para o recolocar e ressignificar sua existência como parte não apenas atômica, mas integrante do todo social considerando em seu pensamento que a construção do ser para além do ser natural, se daria pela própria realização material de determinadas habilidades necessárias para compor, tal qual uma engrenagem, a máquina social como um todo.

E quanto o mínimo essencial para constituir um Estado são quatro ou cinco Homens?

É o que parece.

E quanto a isto: deverá cada um deles contribuir com seu próprio trabalho para o uso comum de todos? Por exemplo, um agricultor fornecerá alimento a todos, dependendo quadruplamente tempo e trabalho para produzir alimento a ser partilhado por todos? Ou não se incomodará ele com isso, produzindo um quarto desse alimento em um quarto do tempo, gastando os outros três quartos um na construção de uma casa, um na produção de roupas e fabricando sapatos, não se preocupando em se associar com os outros, mas se atendo ao seu próprio negócio isoladamente?

Já em tempos hodiernos, talvez seja proveitoso neste momento do trabalho, complementar o pensamento com a crítica radical da escola italiana sobre a concepção do

\footnotetext{
${ }^{74}$ PLATÃO. A República (ou da justiça). Livro segundo, 370. Tradução, textos e notas: Edson Bini. Bauru/SP: EDIPRO, 2006, p.103
} 
ser humano enquanto pessoa de direitos que vai ao encontro do pensamento esposado nesta construção porque enfatiza na visão de $\operatorname{Rodotà~}^{75}$ que a redução de toda a experiência humana a "sistemas", imola e nega um outro conceito de pessoa humana ligado à realidade histórica e concreta, sacrificando a concretude da própria vida "que è vita dell'uomo nella società e dela società nell' uomo in nome di uno schematismo rígido che si é preteso sostituire alla realtà, immolata alle esigenze di una pretesa 'analisi scientifica ${ }^{76,, "}$.

Contudo, ainda na visão do mestre italiano não se nega que a invenção de um sujeito de direitos como uma instituição, um constructo inserido no mundo jurídico, permanece como o grande êxito da modernidade, de onde se vai melhor compreender suas características e sua função histórica ${ }^{77}$. A crítica, todavia, concentra-se na construção jurídica antiga que repassa a esse sujeito todos os males atribuídos à uma hipertrofia de seu conceito.

Para além de uma aventura conceitual e linguística, importa enfatizar que existe uma força irrepreensível, realística, no referimento da pessoa que deve ser reconstruída abandonando-se uma mera simplificação da visão de uma estrutura jurídica abstrata para buscar a reconstrução desse sujeito como um ser concreto na realidade jurídica e imerso num contexto de solidariedade e eticidade.

"L'affermazione dela soggetività è il modo per attribuire pienezza alla persona $^{78,}$ e essa plenitude não pode implicar no seu isolamento, num egoísmo ante a vida em sociedade, porque se assim se entender haverá por certo uma interrupção do

\footnotetext{
${ }^{75}$ RODOTÀ, Stefano. Il diritto di avere diritti. Op.cit, p.142

${ }^{76}$ Que é a vida do homem na sociedade e da sociedade no homem (humana) em nome de um esquematismo rígido que pretende substituir a realidade imolada por conta das exigências de uma pretensa análise científica (tradução livre).

${ }^{77}$ Idem, ibidem.

${ }^{78}$ RODOTÀ, op.cit. p.144-145. A afirmação da subjetividade é o modo para atribuir plenitude à pessoa (tradução livre)
} 
desenvolvimento da intersubjetividade que é marca evidente dos dias atuais. Mas, o que jamais se pode olvidar é que o delineamento deste conceito de sujeitos, em si mesmo, designa o indivíduo como o fundamento universal sobre o qual se sustenta tal conceito.

Nesta visão com viés estritamente humanístico, há um momento na reflexão da ciência jurídica em que o sujeito abstrato não aparece mais como um instrumento ou como uma máscara (da raiz do verbo personare) capaz de compreender a realidade através de um elevado formalismo. Tal formalismo, fruto de um constructo jurídico ao contrário converte-se num impedimento, um verdadeiro obstáculo. Na visão do insigne jurista italiano a construção formal do sujeito em face de uma total abstração tende a cancelar o próprio sujeito que perde a capacidade de autorreconhecimento.

E é interessante porque na posição crítica da escola italiana, o termo pessoa é destinado pela ciência jurídica a um processo de abstração da condição material pura do ser para determinar sua função, a exemplo das pessoas naturais ou pessoas jurídicas. Neste caso então, existe uma tendência a conceituação de pessoa como que oculta da realidade, substituída por uma convenção jurídica o que de fato suprimiria da pessoa sua capacidade de estar no mundo enquanto ser, sendo relegada ao arquétipo de mero sujeito. Um mero destinatário do resultado normativo.

É bem verdade que as posições no direito brasileiro e italiano, de onde se buscou a crítica, qualificam o indivíduo enquanto sujeito de direitos por sua capacidade jurídica considerada como um atributo jurídico que lhe concederia a aptidão necessária para adquirir direitos e contrair obrigações. Mas, no que tange a este trabalho, apetece mais ao objeto a exegese que expressa tal capacidade num reconhecimento de direitos em face de um critério de garantias fundamentais por parte do Estado a partir da norma fundamental, um complexo sistema de direitos invioláveis do homem, que acima de tudo visam reconhecer sua existência, sua dignidade. 
O que se busca na concepção crítica que ora se levanta é um resgate da força realística do referimento à pessoa, que deve ser reconstruída abandonando-se a simplificação a uma mera estrutura jurídica, recusando-se a uma separação do sujeito enquanto pessoa de todo contexto, assim como, recusando-se a uma transcendência e abstração desse sujeito a pretexto de inseri-lo numa dimensão jurídica a qualquer custo.

Agora vale lembrar que essa construção do sujeito de direitos como um conceito abstrato não implica necessariamente em seu isolamento ou na interrupção do desenvolvimento do processo de intersubjetividade pois ao Direito relega-se este papel de atribuir finalidades por via normativa, o que de fato é um processo de abstração. Mas, o que jamais se pode esquecer é que o sujeito, designa em si mesmo um indivíduo que é o fundamento universal que esse conceito exprime.

O ponto central desta racionalidade perpassa o processo de emersão do conceito de pessoa através de sua constitucionalização. Na construção do complexo sistema constitucional a relevância atribuída à pessoa exigiu um reconhecimento de uma base de princípios tendo por eixo fundamental o princípio da dignidade desta pessoa, resgatado a partir de um critério dialético entre a igualdade formal e substancial que configuram uma conquista inafastável nessa travessia do homem privado até ser inserido num contexto substancial no seio constitucional.

Desta forma o sistema jurídico como um todo, seja no tocante à formação das relações jurídicas estabelecidas em todos os níveis de interação dos entes em sociedade, seja nas intercorrências subjetivas, o que ocorre é verdadeira migração para uma dimensão solidária tanto do sujeito e consequentemente da norma. ${ }^{79}$

Como já delineado nos parágrafos anteriores o universo privado, assim como o universal transcendem para elevar a pessoa a um novo patamar. Valores albergados a

\footnotetext{
${ }^{79}$ FACHIN, op.cit. p.54
} 
um princípio de igualdade potencializado por estas novas dimensões que dão à pessoa não apenas uma estrutura normativa como escudo, mas a tornam protagonista de todo processo evolutivo e comunicacional dos sistemas jurídicos internos, o que sem dúvida alguma é o escopo das transformações pelas quais passa o Direito civil.

A pretexto de se estar levantando aqui a crítica aventada na escola italiana, cita-se apenas como ilustração o artigo $2^{\circ}$ daquela Constituição, que assevera um átimo do pensamento já bastante evoluído desta concepção do homem enquanto indivíduo até sua colocação enquanto ente social:

La Repubblica riconosce e garantisce i diritti inviolabili dell'uomo, sai como singolo sai nelle formazioni social ove si svolge la sua personalità, e richiede l'adempimento dei doveri inderogabili di solidarietà politica, economica e sociale. ${ }^{80}$

Sobre este mesmo ideal não é descipiciendo ilustrar que em nossa República, a Constituição Federal ${ }^{81} \mathrm{em}$ seu artigo $1^{\circ}$, inciso III, consagrou a pessoa em sua dimensão de sujeito passível de dignidade colocando este preceito numa acepção de princípio (e antes de tudo valor) fundante da própria existência do Estado. É o ideal da concretude de pessoa de direitos em sua concepção de sujeito constitucionalizado

Mas, de forma alguma a transformação da pessoa enquanto realidade concreta em indivíduo e após, sua inclusão enquanto sujeito de direitos, desnatura ou contradiz

${ }^{80}$ ITALIA. Costituzione della Repubblica Italiana. Roma: Libreria del Senato, 2009. A tradução que fazemos deste texto deixa clara a acepção adotada pela escola italiana: A república reconhece e garante o direito inviolável do homem, seja como indivíduo seja em sua formação social (grupos sociais), onde ele expressa sua personalidade, e exige o cumprimento do dever inderrogável (imperativo) de solidariedade política, econômica e social.

${ }^{81}$ A dignidade foi objeto de referência direta nos seguintes dispositivos: art.170, caput ( a ordem econômica tem por finalidade assegurar a todos uma existência digna); art.226, $\S 7^{\circ}$ (ao se fundar o planejamento familiar nos princípios da dignidade da pessoa humana e da paternidade responsável); art.227, caput (ao se assegurar a dignidade à criança e ao adolescente); art. 230, caput ( ao se ter por objetivo a proteção da pessoa idosa, defendendo sua dignidade e bem estar), assim como no artigo 79 do ADCT (criação do Fundo de Combate e erradicação da Pobreza, cujo objetivo é "viabilizar a todos os brasileiros acesso a níveis dignos de subsistência). CANOTILHO, Joaquim José Gomes; MENDES, Gilmar Ferreira; SARLET, Ingo Wolfang; STRECK, Lenio Luiz; LEONCY, Léo Ferreira. Comentários à Constituição do Brasil. São Paulo: Almedina, 2013, p.123-124 
uma teoria sistêmica para determinar os processos de evolução - Luhmaniana- dos sistemas, social, jurídico e político. Porque, a visão que estamos tentando demonstrar aqui neste instante do texto estabelece a análise a partir do destinatário da comunicação. O homem visto como átimo do sistema social enxergado a partir de si, considerando ser ele o titular de todo e qualquer direito.

Assim, antes de ser destinatário do resultado da diferenciação sistêmica que por si só acontece, o homem precisa ser guindado à esfera de sujeito de direitos dotado de capacidades de exteriorização de sua personalidade, porque senão não haverá endereço de correspondência para qualquer comunicação, ainda que sugestionando levemente a teoria do agir comunicativo em Habermas ${ }^{82}$, que aqui não é alvo de nossa pesquisa, mas, merece ser destacado.

Prima facie destaca-se aqui que não é escopo deste trabalho delinear as divergências entre as teorias sistêmicas em Luhmann ou Habermas, apesar de existirem, principalmente pelos paradigmas de pensamento racional usados por estes grandes autores.

Por outro lado, quando se levantam os objetivos de colocar a pessoa como um ente comissivo torna-se importantíssimo trazer à baila a concepção do agir comunicativo, que neste ínterim confere robustez à argumentação fundante do ser, estritamente naquilo que se propõe neste singelo trabalho.

E para Habermas, o agir comunicativo parte do pressuposto de um processo de interpretação cooperativo em que os sujeitos se manifestam sobre algo no mundo subjetivo, no mundo social ou no mundo objetivo, mesmo que se referindo apenas a um deles.

${ }^{82}$ HABERMAS, Jürgen. Teoria do agir comunicativo, 2; sobre a crítica da razão funcionalista. Tradução: Flávio Beno Siebeneichler. São Paulo: Editora WMF Martins Fontes, 2012, p. 219 e ss 
Esse sistema de referência leva os participantes a construção de elementos interpretativos e definições comuns relativas à situação de sua ação. A resultante deste processo pode levar à contestação da validade de qualquer dessas exteriorizações pelos agentes em comunicação sem que se olvide da análise de que existe entendimento sobre a validade da exteriorização ou da referência feita a um dos mundos citados acima.

Mas, o reconhecimento subjetivo da pretensão de validade que um dos agentes sobreleva, leva ao consenso, tão criticado na teoria dos sistemas de Luhmann, mas que se repita, aqui serve de base valiosa para a determinação da intersubjetividade em relações interpessoais e normativas em matéria de Direito Civil, o que se depreende da análise da moral inserida na própria boa-fé, num exemplo inicial.

Isso porque, como acentua Habermas no desenvolvimento de seu pensamento o aspecto de base do agir comunicativo é constituído pelas situações que se postam diante dos agentes que manifestam suas vontades e consciências, de modo que aja conformação. Por este prisma os atores passam a utilizar de um agir estratégico orientado pelo entendimento.

Tal processo de definição continuada e de redefinição significa a subordinação de certos conteúdos a determinados mundos- de acordo com o que é tido, respectivamente, como válido: como componente do mundo objetivo interpretado consensualmente; como componente normativo do mundo social, reconhecido intersubjetivamente; ou como componente privado de um mundo subjetivo, ao qual se tem acesso privilegiado. A cada nova definição comum da situação, os atores determinam os limites entre a natureza exterior, a sociedade e a natureza interior renovando, ao mesmo tempo, as diferenças entre eles mesmos na qualidade de intérpretes que se posicionam perante o mundo exterior e perante seus respectivos mundos interiores. ${ }^{83}$

De certa forma, obviamente que a abstração da teoria habermasiana abre um profundo processo de reflexão, mas que de forma alguma afasta-a como paradigma

\footnotetext{
${ }^{83}$ HABERMAS, op.cit. p. 223
} 
demonstrativo da formação de relações intersubjetivas que por sua vez são o combustível para a criação das regras de direito privado, mormente, Direito Civil, mesmo porque se considerar-se o sujeito como protagonista de tais normas é toda importância que a análise deste em participação com outro, tendo como pano de fundo o mundo da vida, acabe por evocar um conjunto de referências que se introduzem num vasto horizonte de situações que tiram de um local de conforto ou solidez um determinado assunto.

Invoca-se assim a necessidade de conformação, que no contexto civilístico se dará pela normatização e mais uma vez, ressalta-se a ingerência de uma substancialidade normativa, ou seja, de uma referência a uma contextualização constitucional que está numa esfera de análise comunicacional "de cima" como quer a teoria dos sistemas em Luhmann.

Claro que, voltando ao aspecto do sujeito existe um nexo entre as estruturas do mundo da vida a partir da linguagem, muito importante neste processo, como também, a tradição valorativa que de certa forma transcende a própria consciência individual sem, contudo, privar o sujeito de conceitos pré-estabelecidos, mas que não os coloca numa posição fora do próprio mundo, porque isto geraria marginalização do sujeito. A capacidade semântica da linguagem e o incremento da cultura, segundo Habermas:

...têm de se adequar não somente à complexidade dos conteúdos culturais armazenados, mas também aos valores e aos padrões de expressão e interpretação. Tal depósito de saber fornece aos membros convicções subjacentes, não problemáticas, que eles têm como garantidas; e a partir delas se forma um contexto de processos de entendimento, em que os participantes utilizam definições da situação, já comprovadas, ou negociam novas. ${ }^{84}$

E se para a teoria aqui descrita a linguagem e todo saber valorativo acumulado constituem o medium dos processos de comunicação é de toda importância para

\footnotetext{
${ }^{84}$ HABERMAS, op.cit. p. 229
} 
continuidade destes, que hajam cercanias que garantam a esses sujeitos a continuidade dos processos, porque quando se fala em mundo da vida este status não condiz necessariamente com a os conceitos formais de mundo, mas de certa forma este mundo da vida constitui para Habermas o lugar comum onde os agentes da comunicação se encontram. Assim, as estruturas deste mundo fixam as regras da intersubjetividade do consenso possível, mesmo que partindo de um dissenso.

Numa ilustração, torna-se clara a capacidade de transcendência dos sujeitos numa relação privada contratual, onde podem levantar uns aos outros a pretensão de suas exteriorizações em torno do objeto pretendido no mundo objetivo, precisamente. E é neste mundo que buscam, como sujeitos de direitos confirmar suas pretensões de validade, calcados nas estruturas dispostas pelo mundo da vida.

O domínio da situação desenvolvida na relação jurídica determinada pelos agentes, como num contrato, ressalta um aspecto teleológico pelos fins buscados pelas partes na consecução do vínculo obrigacional que vão formar entre si um aspecto comunicativo dado o acordo que vão fazer.

O risco do fracasso no entendimento e o risco do insucesso são permeados pela lógica da manifestação de uma vontade livre e consciente, logo, não malograda por vícios de consentimento ou quebra de cláusulas gerais ligadas a preceitos morais como é na boa-fé objetiva.

Então o sujeito, dotado de uma autonomia privada constrói pelo acordo uma norma interna, mas que de nada vale se não condizente com as estruturas impostas pelo sistema jurídico, que no núcleo de discussão que se abrange neste trabalho, perpassam por uma série de normas voltadas a um equilíbrio material dessa relação a fim de preservar não a igualdade formal entre os sujeitos que agem, mas o equilíbrio do vínculo estabelecido entre eles e uma igualdade substancial. 
Por isso mesmo, não se desvirtua da teoria habermasiana o entendimento de que os sujeitos lançam mão de sua reserva de saber, experiências e vivências para realizar intersubjetivamente a comunicação, mas dentro das perspectivas que permitam agir e influir no mundo da vida. E essas perspectivas são normativas, pois caso contrário, terse-ia a construção do consenso no seio de relações negociais reduzida à liberdade contratual ilimitada.

E se o tratamento dado a este mundo da vida lastreia-se em um conceito culturalista na expressão e nos valores de interpretação que servem como princípios sobre os quais os agentes numa interação negociam um senso comum, para Habermas é possível entender esta análise numa perspectiva de construção de uma consciência coletiva.

Neste sentido, a pessoa em Habermas ocupará a posição de protagonista do agir comunicativo, mas ao mesmo tempo será produto de valores coletivos consagrados no grupo solidário em que se encontra, assim como, estará submetido a processos de aprendizagem e socialização constantes, num movimento "circular" ${ }^{85}$ ".

Inegavelmente a construção do ser nesta perspectiva do agir comunicativo é uma constante e cíclica dinamização da ação tendo por pano de fundo o mundo da vida na conceituação habermasiana, o que de fato leva a crer que na transformação dos sistemas, mesmo que na perspectiva que ora se vem defendendo, não é possível destituir a pessoa de seu papel importantíssimo de construtor e cultivador de valores dentro de uma consciência coletivizada que de fato é o ambiente para a apreensão ou não de comportamentos ditos desviantes dentro dos processos comunicacionais.

Se o homem é um fim em si mesmo, não pode ser ele mero destinatário da norma criada. Ao contrário, se observa que a evolução deste ser permeia e intensifica os demais sistemas que em movimentos de comunicação e ação restabilizam expectativas

\footnotetext{
${ }^{85}$ HABERMAS, op.cit. p.321
} 
que serão congruentes se amalgamarem-se com o plantel de tradições, valores e saber acumulados no contexto coletivizado ${ }^{86}$.

Isso por si só conduz a um movimento de criação normativa que vise a par da igualdade substancial e proteção da liberdade como modo de inclusão, desafiar paradigmas vetustos e garantir ao ser enquanto sujeito no mundo da realidade o alcance necessário a uma série de preceitos normativos que visem garantir minimamente uma gama de prerrogativas fundamentais e inafastáveis, sob pena de retrocesso da própria evolução.

E o caminho da construção do homem enquanto titular de direitos, consiste também no desafio de se evitar que a revitalização da discussão sobre o ser enquanto sujeito- coisa, ou instrumento do poder privado, estatal ou mesmo sua "coisificação" que no direito internacional e num processo de mundialização o torne refém de expectativas não congruentes.

A afirmação em si de uma subjetividade é ponto de partida para designar o homem enquanto subjectum, qualitatis moralis est persona" como categoria de sujeito. Porém, a ideia em si pode ser alvo de críticas posto que, denuncia uma característica dessa construção que na visão de Rodotà seria “atributo dell'uomo isolato”. Contudo, na esteira do professor italiano, esta acepção demonstraria que mesmo numa construção abstrata do

\footnotetext{
${ }^{86}$ E são poderosas as palavras de Hanna Arendt ao denunciar uma urgência avassaladora da sociedade em torno de um movimento de revolução em prol de valores cultivados e negados em determinados momentos históricos. Em suas palavras: A necessidade dos processos históricos, originalmente representada na imagem do movimento cíclico, necessário, subordinado a leis, dos corpos celestes, encontrou seu poderoso correspondente na necessidade recorrente a que está submetida toda a vida humana. Quando isso aconteceu, e aconteceu quando os pobres, levados por suas necessidades irromperam na cena da Revolução Francesa, a metáfora astronômica, tão plausivelmente adequada à mudança perpétua, às oscilações do destino humano, perdeu suas antigas conotações e adotou o conjunto de imagens biológicas que sustenta e perpassa as teorias orgânicas e sociais da história, que têm em comum o fato de enxergar uma multidão- a pluralidade empírica de uma nação, de um povo ou de uma sociedade - como um único corpo sobrenatural, movido por uma "vontade geral" irresistível e sobre—humana. (Sobre a revolução. Tradução: Denise Bottman. São Paulo: Companhia das Letras, 2011, p.93)
} 
homem enquanto sujeito de direitos, isso não implicaria em si em um isolamento porque

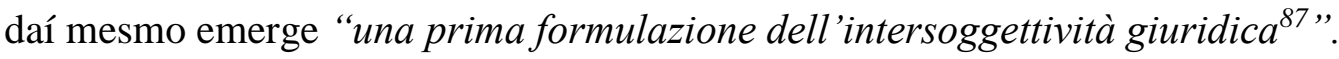

Em singelo pensamento vê-se que esta construção do ser enquanto sujeito de direitos dotado de ação e agir comunicativo, traz consigo a primazia da implementação de alguns dos direitos fundamentais clássicos mais importantes: a liberdade e a igualdade inter-relacionados pelo metaprincípio da dignidade da pessoa humana. A própria noção de sujeito de direitos, advindo da pessoa humana, do ser humano, já demonstra que seu nascedouro parte de uma concepção de igualdade.

Inclusive, em breves análises das cartas que visavam a declaração de direitos do homem, o cerne de tais normas sempre se estabelecia numa neutralização das diferenças para colocar a todos como sujeitos de uma mesma ordem jurídica. E mesmo a sensibilidade da construção filosófica do conceito estar afeta às variações históricoculturais da própria sociedade, o fato é que até o presente as liberdades e a igualdade remanescem como aquisições evolutivas das quais a humanidade não pretende se despojar.

\footnotetext{
${ }^{87}$ RODOTÀ, op.cit. p.135. Primeira formulação de uma intersubjetividade jurídica. (Tradução nossa)
} 


\section{2- A importância da Dignidade da pessoa Humana como eixo fundamental para a (re) construção do Direito Civil}

Não causa dúvida que a dignidade da Pessoa Humana se tornou um dos principais valores erigidos pela humanidade, sendo responsável inclusive pela concretude dos direitos fundamentais então sedimentados ao patrimônio comum da humanidade, positivados ou idealizados, apesar de não se afastar a grande problemática da eficácia dos mesmos no que tange à implementação pelos sistemas constitucionais.

Um aspecto preliminarmente importante deste tempo reside na significação do constitucionalismo como parte do sistema jurídico, e centralmente a dignidade da pessoa humana entendida dentro de Estados democráticos de direitos como princípio objetivo capaz de gerar validade à todas as relações jurídicas e normativas criadas dentro do sistema de direito.

A consagração deste princípio significou uma decisão importante encerrada no consciente coletivo e guindada ao seio constitucional denotando respeito à finalidade e justificação do próprio Estado que existe em função da pessoa humana e não o contrário.

As formas de garantia deste princípio, em que pese a compreensão uníssona de seu conteúdo, revelam uma pluralidade de acepções normativas, limites de alcance e aplicabilidade como ocorre nas democracias ocidentais que se intitulam Estados de Direitos. Nalguns países enquanto regulação deste princípio se dá pela concretude de direitos fundamentais numerus clausus, deduzida em minúcias no bojo do texto constitucional ou analiticamente inseridos, como no Brasil e na Alemanha, em países da common law os mesmos direitos são entendidos sob a perspectiva ideológica não escrita.

Tal diversidade de apresentações traduz em si mesma uma pluralidade de significação dos direitos fundamentais segundo as ordens sociais e jurídicas em que se 
sediarem, demonstrando que não há conformação nem uniformidade. Mas, quanto a dignidade existe um consenso ideológico de que se trata de um valor referente ao ser humano e inafastável em qualquer medida de sua existência. Por isso, a significação do ordenamento jurídico se dá em face da proteção desta acepção que não pode e nem deve sofrer limitação conceitual, sob pena de se aceitar ferida a própria existência do ser humano.

\subsubsection{Síntese da construção de uma ideia de Dignidade a partir de uma visão europeia}

Hesse $^{88}$ evidencia historicamente os esforços da Declaração dos Direitos Humanos de 10 de dezembro de 1948, assim como, a Convenção Europeia de Direitos humanos e a a jurisprudência do Tribunal Europeu de Direitos humanos, para dar concretude a esta tradição enraizada no seio social mundial apesar de sua diversidade de significância, sem descurar obviamente que em sua internalização pelas constituições não se excluem diferenças materiais, ou diferenças de concepção em suas garantias. Mas tais diferenças não ultrapassam a necessária conformidade quanto ao seu conteúdo e interpretação que na concepção do autor citado tendem a evidenciar a validade universal dos direitos sem, contudo, supor uma uniformidade.

Mas de fato, a dignidade da pessoa humana, assim como os direitos fundamentais, iniciou sua trajetória a partir do século XVIII com as magnas Declarações de Direitos Humanos, os Bill of Rights na América e as Declarações francesas de 1789 a 1795, e segundo Hesse ${ }^{89}$ só com muita discussão passaram já entrado o século XIX a integrar as Constituições da Baviera, Baden de 1818, a Constituição de Wurtemberg de 1819 e mais tarde a Constituição de 1850.

\footnotetext{
${ }^{88}$ HESSE, Konrad. Temas fundamentais do direito constitucional. Tradução:Carlos dos Santos Almeida, Gilmar Ferreira Mendes, Innocêncio Mártires Coelho. São Paulo: Saraiva, 2009, p.24 e ss

${ }^{89}$ HESSE, idem ibidem
} 
Em mesmo contexto ${ }^{90}$ ainda afirma que na Alemanha - um dos berços de nosso direito- em que pesem os episódios constitucionais nas Constituições da Baviera e Baden de 1818 e as do império Prussiano, o fato é que na nascença real da teoria de direitos fundamentais calcada na proteção do ser em sua dimensão de dignidade (sentido ainda insipiente neste período) se deu na fundação do Reich na revolução de 1848. Mas, segundo o autor, nem mesmo durante a República de Weimar, em que pese ser ícone da teoria constitucional brasileira para explicar a evolução do constitucionalismo nesta seara, não houve grande extensão, eficácia ou aplicabilidade desta dignidade, mesmo como valor fundante dos direitos fundamentais no Estado germânico.

Já na amplitude do contexto europeu a Convenção Europeia para proteção dos Direitos Humanos e Liberdades Fundamentais o reconhecimento universal e efetivo de direitos que por seu conteúdo são direitos fundamentais, calcados no objetivo de concretizar o ideal de proteção do homem em sua dimensão de dignidade trouxe importante consolidação de bases tidas como fundantes. No entanto, mesmo atualmente, apenas para constar, vê-se às voltas de uma crise na implementação dos direitos das gentes, já que é norma geral de Direito Internacional o que de fato põe obstáculos à efetivação como norma ordinária em vários países signatários.

Apesar disso, Habermas ${ }^{91}$ destaca que os direitos fundamentais não perderam seu conteúdo e sua significância, ressaltando a importância da implementação na Europa de um direito das gentes calcado na formação de uma sociedade intersubjetiva, protegida pelo ideal construído na Europa de preservação dos direitos humanos tendo como carro chefe a preservação da pessoa e sua dignidade, constituída social e politicamente na força civilizadora da jurisdificação democrática que só teria sentido a partir de uma soberania supranacional que é o cerne de suas ideias.

\footnotetext{
${ }^{90}$ HESSE, op.cit. p. 27.

${ }^{91}$ HABERMAS, Sobre a constituição da Europa. Op.cit, p. 39-59.
} 
Ressaltando a crise na implementação destes mesmos direitos e a necessidade de uma autonomia das chamadas "leis da liberdade" (aludindo Kant) a concepção habermasiana fala da implementação dos direitos fundamentais dimensionados não só nas soberanias dos Estados como também no exercício de uma soberania popular ancorada numa legislação universalizadora garantindo a implementação das liberdades a todos dignamente e igualmente.

O primado deste direito supranacional como quer Habermas, institucionalizaria na Europa um acoplamento estrutural entre direito e política diametralmente oposto ao que se vê atualmente, alçando os direitos fundamentais à esfera da comunitarização; igualdade no exercício da autonomia privada (influenciando diretamente as normas de direito civil); solidificação do que o autor chama de "solidariedade civil estatal ou supra estatal ${ }^{92}$ " para a formação de vontades comuns, e neste sentido a proteção da dignidade dos agentes na comunicação por um sistema normativo harmoniosamente transversal entre a norma nacional e supranacional.

De início, apesar haver um embrião para dimensões mais avançadas dessa categoria jurídica como se viu no ideal habermasiano, de fato sua essência inicial sempre foi expressada numa efetividade plena de direitos fundamentais sem olvidar o ideal originário dos mesmo que sempre se basearam numa autolimitação dos poderes do Estado em prol do engrandecimento do ser humano, determinando como valor fundante de tais direitos a dignidade deste ser.

Assim, seguindo a esteira do pensamento de Hesse, o escopo principal dos direitos fundamentais foi e é o de "criar e manter as condições elementares para assegurar uma vida em liberdade e a dignidade humana ${ }^{93}$ ". Daí porque essa concepção alcançou em grande parte o mundo ocidental e principalmente aqueles países calcados em seus

\footnotetext{
92 HABERMAS, op.cit. Passim

93 HESSE, Op.cit. p.33
} 
fundamentos na democracia participativa e ancorada no respeito às liberdades, à participação política, igualdade e claro a dignidade do ser. Veja-se a seguir apenas alguns exemplos no âmbito regional da América do Sul e do Brasil.

\subsubsection{A influência da teoria dos Direitos Fundamentais como concretude de um princípio} da dignidade no contexto latino americano e o Brasil. Um breve olhar do prisma constitucional

$\mathrm{Na}$ formação tanto do constitucionalismo, quanto da implementação dos direitos fundamentais e humanos na América Latina, Wolkmer ${ }^{94}$ levanta críticas ao pluralismo nascente no seio latino americano baseado num conceito emancipador das práticas sociais e movimentos sociais, e denuncia que a independência das colônias americanas, mormente da Espanha e Portugal no início do século XIX, na verdade não significou imediatamente uma ruptura social capaz de inserir o continente latino americano numa nova ordem social onde direitos e garantias fundamentais e humanas (aqui entendida também a dignidade) fossem o escopo da formação do pensamento constitucional. "Paulatinamente, incorporaram -se e adaptaram-se princípios do ideário econômico capitalista, da doutrina do liberalismo individualista e da filosofia positivista $95 \%$

Neste contexto a forte influência eurocentrista dos modelos jurídicos tanto em âmbito público quanto privado, foram capazes de influenciar a formação pensamento constitucional e privatista na América Latina, construindo seus sistemas jurídicos herdeiros de tradições romanísticas ou germânicas e muito influenciados pelas

\footnotetext{
${ }^{94}$ WOLKMER, Antonio Carlos. Pluralismo e crítica do Constitucionalismo na América Latina. In: anais do IX Simpósio de Direito Constitucional. Academia de Direito Constitucional, 2010, p. 143-155

${ }^{95}$ Idem ibidem.
} 
Declarações de Direitos Humanos na França e no pensamento liberal norte americano, porém, inserindo estes ideais em meios contextualizados por oligarquias agrárias, estados escravagistas e controlados por núcleos de poder hegemônico e centralizador.

O resultado deste quadro foi que o início da formação do pensamento latino, caracterizou-se por documentos constitucionais e normas privadas preconizadoras de um Estado fincado no ideal de preservação da dignidade da pessoa, além de, isonomia, igualdade, direitos individuais e garantias sociais todos em torno do ideal humanístico, porém, sem a devida aplicabilidade.

O Direito Civil por sua vez, escanteado do outro lado de um abismo separatista dos domínios entre público e privado, viveu no criticado processo codificatório um processo de estruturação de suas normas, voltadas única e exclusivamente para o resgate e implementação das teorias do patrimônio, direito de família e sucessões, calcadas no escopo de regulação de relações interpessoais, de direitos reais ou familiares sem se preocupar com valores humanitários. Tinha, portanto, caráter unicamente normativo-formal.

Claro que, em dias hodiernos o movimento de transformação dessa realidade carreado pelo constitucionalismo modificou este panorama consideravelmente. Num exemplo, o desenvolvimento do constitucionalismo pluralista na América Latina ganhou expoentes de grande importância como a Constituição Equatoriana com seu pluralismo nacional e intercultural descrito no texto de 2008.

Naquele país, diante da diversidade cultural e ética dos povos indígenas a necessidade de um novo constitucionalismo calcado na real efetividade da igualdade diante das diferenças culturais e a preservação da dignidade de povos num contexto de diferenciação, acabou por se tornar um dever ser do Estado na consecução dos fins da 
própria constituição. É o surgimento do chamado Estado Plurinacional e Intercultural, como preconiza Grijalva. ${ }^{96}$

Neste Estado dialógico, a dimensão dos direitos fundamentais e humanos é guindada a patamares horizontais para concretizar o ideal de dignidade humana com ampla participação não só nas esferas jurisdicionais como sociais dos interessados na sua eficácia, plenitude e aplicabilidade imediata, daí porque se torna um Estado concretista e garantista de desta dignidade através da implementação destes direitos.

No Brasil a efetivação plena da dignidade da pessoa humana, foi guindada ao patamar de metaprincípio, além de ser uma fonte dos direitos fundamentais, o que decorreu principalmente da Constituição de 1988 e a afirmação do Estado democrático de direitos no seio de nosso território. O texto atual da Constituição Federal brasileira deu a merecida relevância ao tema da dignidade como um alicerce da República e tematizou os direitos fundamentais e humanos, principalmente por que o Brasil passou por um processo de redemocratização, após mais de vinte anos de um regime militar autoritário.

Evidente que ao tratar da dignidade da pessoa humana como valor no seio brasileiro, não se pode deixar à penumbra o fato de que o caráter analítico de nosso texto constitucional imprimiu à norma constitucional um caráter plural quanto a disseminação dos direitos fundamentais em seu texto o que de fato, favoreceu e muito a propagação dos ideais de objetivação de tais direitos e a elevação da dignidade como eixo fundamental na inter-relação dos direitos fundamentais com o ordenamento interno.

A dignidade como um dos valores supremos da república e as dimensões de direitos consagrados como fundamentais e sua contextualização histórica foram contributo para a formação do pensamento constitucional brasileiro. Desta forma sua

\footnotetext{
96 GRIJALVA, Augustín. O Estado Plurinacional e Intercultural na Constituição Equatoriana de 2008. In: Povos Indígenas: Constituições e reformas Políticas na américa Latina / [organizador Ricardo Verdum]. - Brasília: Instituto de Estudos socioeconômicos, 2009, p. 118
} 
inserção, dentro do escopo de norma protetiva das liberdades e garantias do homem por intermédio de uma mediação jurisdicional, veio acontecendo de forma progressiva dentro de períodos específicos que neste humilde trabalho não ousamos delinear, mas vale a pena citar em exemplos, a liberdade individual, o devido processo legal, propriedade, meio ambiente, garantias individuais, sociais, a ordem econômica baseada na livre iniciativa e preservação da dignidade em vários aspectos da Constituição ${ }^{97}$, etc.

Seja como for, em caráter autoaplicável ou mesmo programático, Sarlet $^{98}$ evidencia que os direitos fundamentais para além de sua função meramente regulatória ou limitativa do poder estatal nas mais diversas searas, constitui umbilicalmente o próprio Estado de Direitos que por sua vez existe em função da consecução do ideal de preservação da dignidade da pessoa humana.

Neste raciocínio, o poder estatal só se legitima e se justifica pela realização dos direitos do homem. Usando o pensamento de Ferrajoli ${ }^{99}$ é que aquele autor estabelece um vínculo substancial entre direitos fundamentais e poder estatal, de tal sorte que a validade substancial de normas produzidas se fundam no respeito aos direitos fundamentais que, por sua vez, retiram sua força normativa como elementos concretizadores da dignidade da pessoa humana. Sob esta ótica os direitos fundamentais saem de qualquer esfera do ideário de direito natural ou mesmo ideológico puro e simples para alçar status de elementos da ordem jurídica objetiva com sentido axiológico fundamentador de todo o ordenamento jurídico no Brasil.

Isto porque a dignidade da pessoa humana para além de uma dimensão ontológica, possui uma dimensão histórico-cultural, enraizada nas diversas gerações da

\footnotetext{
${ }^{97}$ Cf. nota de rodapé 79.

98 SARLET, Ingo Wolfgang. A eficácia dos direitos fundamentais: uma teoria geral dos direitos fundamentais na perspectiva constitucional. 2.tir. 10.ed. ver. Atual. e ampl. Porto Alegre: Livraria do Advogado, 2009, p. 56-65

${ }^{99}$ FERRAJOLI, Luigi. Derechos y Garantias. La Ley Del Más Débil. Madrid/Es: Trotta, 2008, passim
} 
humanidade, logo, vinculada à própria condição humana individualizada e elevada ao seio social. Assim, a relevância desta dignidade não se encontra somente no universo dos valores, mas concretiza-se objetivamente através dos direitos fundamentais e sociais, já que possui significância em função da intersubjetividade que é marca de nosso tempo.

E a concepção de que os direitos fundamentais ensejam o arcabouço da democracia moderna como dimensão negativa da dignidade a fim de refrear o poder estatal, também alcança guarita no pensamento de Habermas, como já havíamos singelamente pautado acima, tanto quanto ao conceito de soberania popular, quanto ao conceito de Estado Democrático de Direito o que neste particular não é o alvo deste trabalho, apesar de não podermos deixar de mencionar.

2.2.3 Objeto, valoração da dignidade da pessoa humana como resultado da hipercomplexidade social. Breve visão Luhmaniana sobre o Estado do bem-estar

Do que se depreende nas linhas aqui apresentadas resta demonstrado que o principal objeto dos direitos fundamentais calca-se na liberdade do homem no seio de uma sociedade que garanta a uma só medida essa liberdade tanto em caráter individual quanto coletivo, ou seja, criar os ambientes normativos necessários à realização do ideal de dignidade do ser. Deste escopo é que se evolui para um outro que é a dignidade humana como mote de implementação de direitos fundamentais, como metanorma, um eixo fundamental que servirá como um dos principais pontos de toque entre a norma Civil e a norma Constitucional.

Em consenso com estes alvos estes direitos fundantes não só da ordem subjetiva como também e principalmente da objetiva enquanto ensejadores de direitos subjetivos e intersubjetivos, se colocam como limites ao poder do Estado. 
Como instrumentos de liberdade a dignidade da pessoa humana e os direitos fundamentais devem ser considerados como princípios objetivos e, portanto, elementos validativos do próprio sistema normativo o que será defendido e mostrado ao longo do trabalho em tópico vindouro.

No mesmo enredo, tais direitos são relevantes e os mais importantes pináculos na sustentação do ordenamento democrático, não só em âmbito de direito público constitucional, mas em todo contexto da assim chamada ordem pública porque são geradores de direitos civis.

Esta contextualização traz inarredáveis reflexos, em particular neste trabalho, para os conteúdos de direito privado (se é que se pode definir assim) traduzindo-se em critérios significantes e validadores de relações jurídicas de caráter interpessoal ou mesmo de direitos reais, como por exemplo, a ampla proteção ao direito de propriedade ou a boa-fé objetiva nos contratos que encontra seu substrato em princípios de eticidade que são em sua gênese representações de valores ligados à dignidade.

Neste plexo o conteúdo dos direitos fundamentais determina que a interpretação do ordenamento demande antes de tudo um diálogo junto ao sistema axiológico destes direitos buscando seu cerne fundante. Em seara do Direito Civil, como é o caso deste trabalho, uma lide em torno de objeto material ou imaterial numa relação obrigacional, por exemplo, continuará sendo um impasse civilístico, todavia, entrelaçado com o sistema de direitos fundamentais emanados do ideal de dignidade, que como torrentes emanadoras de princípios objetivos a um só tempo dão sentido, como também validam ou não a relação se em conformidade com tais valores e princípios superiores.

A par deste pensamento é que acreditamos ser fundamental tentar demonstrar a teoria dos direitos fundamentais como diferenciação social sob a ótica da teoria dos 
sistemas de Luhmann e demonstrar a importância de sua institucionalização e realização no Estado do bem-estar.

A constituição sem dúvida é o resultado da sociedade moderna, evoluída e inserida numa hipercomplexidade funcionalmente diferenciada, conforme nos ensina o Marcelo Neves ${ }^{100}$. No contex to desta evolução, devemos entender pela visão de Luhmann como as constantes transformações do improvável em provável traduzem verdadeiro paradoxo da probabilidade do improvável. Por esta perspectiva a evolução ocorre mediante a reprodução dos elementos construídos dentro do próprio sistema que se constituem em elementos diversos dos já existentes. Esses eventos desviantes determinarão a variação do sistema, mas não sua evolução completa. O dissenso aqui torna-se fulcral para o próprio processo evolutivo, afastando-se, todavia, a ideia habermasiana de busca pelo consenso a todo custo. Mas, lembre-se ao leitor que esta análise se dá num plano heterárquico, mas superior ao contexto social. Visa-se aqui determinar a valoração dos direitos fundamentais neste processo comunicacional.

Assim este processo de variação na teoria dos sistemas corresponde a um modelo que não fornece qualquer interpretação do futuro, pairando, portanto, a incerteza quanto aos processos de seleção e restabilização do sistema como já dito no capítulo anterior, o que não afasta a presença de mecanismos limitadores de expectativas incompatíveis com a realização de direitos fundamentais.

Sob este enfoque o acoplamento estrutural ${ }^{101}$ entre dois sistemas autônomos resulta numa relação auto- referencial dos sistemas de modo que ambos se interpenetram gerando episódios de ingerência, como por exemplo, tanto da política no direito quanto do direito na política, relações de dependência e independência, porém, sempre calcadas

\footnotetext{
100 NEVES, op.cit.p 60 e ss.

${ }^{101}$ NEVES, Marcelo. A constitucionalização simbólica. São Paulo: $3^{\mathrm{a}}$ ed.WMF Martins Fontes, 2013, passim.
} 
na medianiz recíproca. Há explícita subordinação entre os códigos binários lícito/ilícito e poder/não poder.

Isso porque nem todas as expectativas geradas deste acoplamento serão selecionadas ou gerarão restabilização do sistema. Alguns desvios simplesmente serão rejeitados ou relegados ao esquecimento.

Este processo é baseado em risco quanto aos critérios de seleção de expectativas, já que se fala no risco da decisão, e pode expor-se a perigos quando a variação política não encontra medianiz no direito e vice-versa, já que aqui o problema é o dano causado por um ou outro enquanto ambientes entre si.

Nesta esteira a restabilização funciona como motor da variação. O resultado disso é que numa sociedade hipercomplexa, os critérios de seletividade tendem a se tornar cada vez mais complexos provocando, frise-se, pressão seletiva e diferenciação também em relação aos subsistemas acoplados estruturalmente (direito - política) que formam a Constituição. Daí porque enquanto concepção político ideológica, sua evolução (da Constituição) transcende o texto magno escrito.

Mas não somente isso, a Constituição também desempenha um papel importantíssimo de limitadora de expectativas incompatíveis com o sistema jurídico, que se formem no ambiente. Trata-se de uma função "descarregante" possível "apenas mediante a adoção do princípio da não-identificação ${ }^{102}$ ". Isto significa em singelas palavras que a Constituição enquanto mecanismo operacional do sistema jurídico não se queda refém a nenhuma identidade total, quer seja política, social, religiosa, etc.

Considerando este "princípio da não identificação" chegamos ao ponto de análise da institucionalização dos direitos fundamentais. Por institucionalização Neves

102 NEVES, idem, ibidem 
ensina ser o consenso suposto, ou seja, a normatização destes direitos no bojo da própria Constituição em dimensão temporal, social e material (objetiva, a nosso sentir).

Tal processo institucionalizador é a concretude em vários aspectos da dignidade da pessoa humana, considerando aqui geradora dos direitos fundamentais.

Este critério encontra crivo no conceito de diferenciação do sistema. Como dissemos, uma característica da sociedade moderna é a hipercomplexidade. Esta por sua vez, gera maior pressão seletiva, que por sua vez gera mais contingência. Esta contingência entendida como uma expectativa da qual não se tem condição de saber o resultado, logo inesperada, é uma resultante da comunicação entre alter e ego. Isso por si só implica maior diferenciação do sistema funcional.

Neste jaez teórico o Direito como um todo, mormente, nos pontos de interlocução Civil-Constitucional, "servem ao desenvolvimento de comunicações em diversos níveis diferenciados" 103 . Por este prisma pode-se afirmar aqui que os direitos fundamentais serão, em sua função de concretude da dignidade da pessoa humana, facilitadores da comunicação na diferenciação dentro da hipercomplexidade social. Servirão também para evitar o perigo da desdiferenciação do sistema, que é justamente o implemento contrário ao conceito estabelecido no princípio da não identificação. Esta significaria, noutras palavras, reduzir a níveis drásticos os processos de evolução do sistema, as ações de comunicação e contingência e por fim a própria diferenciação. Seria como se estivéssemos novamente num regime totalitário onde a normatização fosse instrumento servil à unilateral vontade do dominante.

Por esta visão de análise é que se pode depreender a realização da dignidade da pessoa humana a partir de um Estado de bem-estar compreendido como o Estado em sua dimensão de inclusão política e jurídica, ambas realizadas abarcando aqui o sentido

103 NEVES, A constitucionalização simbólica, p. 75 e ss 
de inclusão luhmaniano defendido por Neves, em suas dimensões de acesso de toda população às prestações de cada um dos sistemas sociais, e dependência da conduta individual a cada uma dessas prestações.

A total marginalização de grupos conduz inexoravelmente à inacessibilidade às prestações do sistema social e ao mesmo tempo total dependência destas prestações, o que para Luhmann num primeiro momento de seu pensamento teórico seria fator de subintegração. A sobreintegração, em contrapartida, neste pensamento, implicaria na total independência quanto as regras estabelecidas a partir da institucionalização dos direitos fundamentais e total acesso ás prestações do sistema social o que consequentemente significaria no pensamento defendido neste trabalho, realização da dignidade em sua amplitude máxima .

Nesta via de pensamento a realização da inclusão política e jurídica será definidora do Estado do bem-estar. Claro que aqui, não se fala de intervencionismo ou mesmo assistencialismo como mecanismos de implementação de direitos. Neste ponto se pode definir o pensamento no sentido de que o Estado por si, encontra limites na institucionalização dos direitos de toda ordem encerrados no texto e na acepção dinâmica da constituição, considerando aqui a dignidade como este limite a ser respeitado, levando a concluir no mesmo sentido da crítica levantada por Teubner ${ }^{104}$, citado por Neves de que na verdade o que existe é uma sociedade do bem-estar que tem por escopo a busca incansável pela inclusão de todos os seus setores sociais, amparada imprescindivelmente pela Constituição e seu fundamento na dignidade da pessoa humana.

Isso decorre do fato de que a inclusão de toda a população nos diversos sistemas sociais e a diferenciação funcional da sociedade pressupõem-se reciprocamente, na medida em que a exclusão de amplos grupos sociais e a auto-referência operacional dos sistemas funcionais são incompatíveis. Nessa perspectiva pode-se afirmar que, na sociedade supercomplexa de hoje, fundada

${ }^{104}$ NEVES, A constitucionalização simbólica. p. 77, nota 93 
em expectativas e interesses os mais diversos e entre si contraditórios, o direito só poderá exercer satisfatoriamente sua função de congruente generalização de expectativas normativas de comportamento enquanto forem institucionalizados constitucionalmente os princípios de inclusão e da diferenciação funcional e, por conseguinte, os direitos fundamentais sociais (Estado de bem-estar) e os concernentes à liberdade civil e à participação política $^{105}$.

De fato, a significância e valoração, da dignidade da pessoa humana enquanto metaprincípio, encontra substrato na realização política e jurídica da inclusão no sentido do acesso social a todas as prestações do sistema gerando, por conseguinte, integração.

Noutras palavras, em sendo a Constituição o instrumento no qual os direitos seriam institucionalizados, e ainda, sendo esta fonte de limitação a expectativas incompatíveis com o sistema jurídico, então, enquanto subsistema do sistema jurídico a Constituição exerceria o papel de norma implementadora de tais direitos à guisa de realizar o ideal valorativo de preservação do ser em sua dignidade.

Isso de certa forma vincularia sistemas internos ao sistema jurídico, como o Direito Civil em sua construção interna (podemos até falar em operações de autopoiese nos moldes aqui delineados ao longo deste texto), de modo que o resultado da estabilização de expectativas congruentes esteja sempre no sentido de comungar com a realização normativa dos preceitos insculpidos no seio constitucional e refletidos na norma privada do Direito Civil, culminando, por consequência, em processos de inclusão e suficiente integração, no sentido primário do pensamento de Luhmann.

Este processo, ao que parece implica em transformação das regras de Direito Civil, embasadas em toda a plêiade de direitos e garantias fundamentais, tendo por paradigma as normas constitucionais implementadoras desses direitos e por mote a realização in concreto do princípio torrencial da dignidade da pessoa humana. Do contrário essa vinculação cairia no vazio.

${ }^{105}$ NEVES. op. cit. p. 78 
Destarte, empós essas breves ilações, passa-se a outra etapa evolutiva do raciocínio implementado neste trabalho para buscar uma leitura da pessoa humana enquanto sujeito de direitos e o caminhar linear para o princípio da dignidade humana.

\subsubsection{Liberdade e direitos fundamentais como pressupostos da dignidade da pessoa} humana em face do sujeito de direitos

A par da construção de uma ideia da pessoa considerando que esta "não é um valor universal radicado na essência racional e imutável do homem, antes um valor real e objetivo, historicamente condicionado, de um determinado ordenamento positivo ${ }^{106 ",}$ pode-se afirmar que do conceito de pessoa ao de sujeito de direito resulta, na atualidade que seja um conceito social, cunhado numa consciência coletiva, uma vez que, somente em sociedade o homem pode ser dotado de direitos e deveres divorciado de um solipsismo egóistico do ser conforme demonstrado em tópico anterior.

E o paradigma deste pensamento concentra-se na liberdade da pessoa no contexto de uma sociedade livre considerada a partir das limitações normativas que o viver em sociedade impõe, onde as pessoas são equipadas de poderes de autonomia privada para decidir por si mesmos os rumos de suas relações jurídicas e contribuir responsavelmente para o crescimento e desenvolvimento do todo social.

A consecução de tais pressupostos forja toda a estrutura de direitos subjetivos dos indivíduos e não se constitui senão a partir do reconhecimento da pessoa como titular

\footnotetext{
106 MESSINETTI, David. Personalità (diritti dela). In: Enciclopedia Giuridica Giuffrè. Milão, 1984, verbete, p. 355 e 356, apud CUNHA, Alexandre dos Santos. Dignidade da pessoa humana: conceito fundamental do Direito Civil. In: COSTA-MARTINS, Judith. A reconstrução do Direito Privado, op.cit. p.234. E no original descrito na obra consultada lê-se: Non è um valore universale radicato nell'essenza razionale e imutabile dell'uomo, bensi um valore reale e oggetivo, storicamente condizionato di um determinado ordenamento positivo.
} 
desses direitos e mais, dotada de personalidade para exercê-los mediante manifestações volitivas positivas projetando no seio das relações privadas e sociais sua liberdade.

E essa liberdade concedida é fator de inclusão do ser no contexto coletivo, porque importa em autodeterminação limitada por normas objetivas amparadoras e também na sua participação em todos os níveis de interação social, como a vida política, cultural e etc.

Neste mesmo viés, ainda pertence às origens da tradição dos direitos fundamentais a concepção de que os mesmos se convertem em princípios objetivos da própria ordem Constitucional para assegurar essas liberdades e todo o processo de formação do contexto social coletivo como já havíamos frisado anteriormente voltados para o escopo principal de garantir a dignidade da pessoa humana. E é certo aqui tais direitos não se limitam à função precípua de serem direitos subjetivos de defesa do sujeito contra atos estatais, mas para além disso, entabulam uma relação de remissão e complementação com a esfera subjetiva de tais direitos.

Sarlet ${ }^{107}$ evidencia em sua obra o evocado exemplo que muitas doutrinas utilizam para determinar originalmente esse caráter objetivo dos direitos fundamentais. Cita a decisão prolatada pela Corte Federal Constitucional (Bundesverfassungsgericht) no caso Lüth, na qual, ficou consignado que os direitos fundamentais não se limitam simplesmente á função de serem direitos subjetivos de defesa do indivíduo contra atos do poder público, mas que, além disso, constituem decisões valorativas que vinculam o

107 SARLET, Ingo Wolfgang. A eficácia dos direitos fundamentais: uma teoria geral dos direitos fundamentais na perspectiva constitucional. Op.cit., p.143 e ss. E ao analisarmos a decisão proferida em 1958 pela Corte Alemã, pudemos extrair dentre outras coisas, a eficácia horizontal dos direitos fundamentais, a respeitabilidade ao direito de expressão, a dignidade do reclamante e claramente a aplicação de razoabilidade no decisório, que envolvia de um lado uma questão de direito de privado ligada a um pedido de indenização de cineastas alemães (principalmente Veit Harlan) com base no $\S 826$ do BGB, e de outro lado, o direito fundamental de liberdade de expressão de um judeu - Erich Lüthinsatisfeito com o fato de um filme feito à época conter incitação à violência contra Judeus. 
ordenamento jurídico e fornecem diretrizes para todas as esferas estatais como pressupostos jurídico-objetivos.

Neste cenário, ainda em Hesse ${ }^{108}$ o significado dos direitos fundamentais como preceitos objetivos se colocam como limitadores das competências legislativas, administrativas e judiciais que encontram seu limite sempre nestes direitos que atuam como normas protetivas na medida que vedam a intervenção intempestiva e colonizadora do Estado quando age em detrimento da mantença de tais direitos o que fatalmente milita em confronto com a dignidade do ser.

Dessa forma, os direitos e garantias como um todo operam como limite da ação estatal, servindo como alicerces do próprio ordenamento jurídico obrigando o próprio Estado a proteger os conteúdos que tais direitos garantem, como o sufrágio livre, as liberdades em geral, direitos associativos e outros que por sua vez convergem para a pessoa humana.

Essa concepção ampla do que se entendeu por dignidade e sua manifestação concreta na seara de garantias fundamentais, manifesta rejeição com qualquer tipo de interpretação formal, visando, por conseguinte, uma noção material que compreende um sentido objetivo ínsito nesse universo de direitos, guindando-os ao patamar de princípios do ordenamento tornando defesa qualquer tentativa de relativização, mesmo porque tais garantias contêm em si mesmos princípios de ordem superior e um dos principais é a dignidade da pessoa humana.

Sob este viés é possível concluir que a busca do ambiente normativo necessário à concretude da dignidade como fundamento republicano influi em todo o ordenamento, mormente nas relações entre particulares, ou seja, relações de cunho privado. E, inclusive, promoverá a transformação da norma civil paulatinamente,

${ }^{108}$ C.f. Temas fundamentais do direito constitucional, p.36 
conforme já vimos insistindo, para afastar qualquer entendimento de que se trata de mera adequação hermenêutica do Direito Civil à norma Constitucional pura e simplesmente.

Da mesma forma os direitos humanos também se desenvolveram em resposta as muitas violações de valores morais ligados à dignidade da pessoa humana o que não poderíamos deixar de citar. E nesta relação interna de direitos ditos humanos, o que se pode dizer é que estes direitos foram delineados para uma implementação efetiva e eficaz destes valores morais cultivados no seio social. Neste contexto a dignidade, como se veio frisando, se funda como uma fonte moral desses direitos, ou melhor dizendo, como um eixo fundante desses direitos, tendo um papel mediador entre a aplicação de tais direitos em termos de um ordenamento coercitivo.

Interessante aqui a defesa da tese esposada por Habermas ${ }^{109}$, o qual sustenta que o conceito de dignidade não é um ideal vazio e retórico, mas que ao contrário converte-se em fonte de onde derivarão todos os direitos fundamentais à medida das experiências concretas advindas com as violações desta dignidade.

E isto se dá justamente pelo caráter abstrato de tais direitos que padecem de especificação o que claramente ocorre em uma contextualização cultural o que também pode conduzir a resultados diversos em cada um destes contextos. Assuntos controvertidos que invoquem juízos éticos, como a validade de casamentos homoafetivos, pesquisas envolvendo células tronco de embriões, liberdades como o direito ao sigilo, o direito de imagem, as novas manifestações de famílias e o direito à adoção e sucessão em famílias plúrimas, são alguns exemplos.

\footnotetext{
${ }^{109}$ HABERMAS, Jürgen. The concept of human dignity and the realistic utopia of human rights. Article first published online: 20 jul. 2010 / DOI: 10.1111/j.1467-9973.2010.01648.x / (C) 2010 The Author. Journal compilation (c) 2010 Metaphilosophy LLC and Blackwell Publishing Ltd / Metaphilosophy Volume 41, Issue 4,.p. 464-480 (tradução livre por Professor Menelick Carvalho Netto)
} 
Logo, como apregoa Habermas, ${ }^{110}$ o recurso ao conceito de dignidade da pessoa humana como um preceito objetivo, sem dúvida, conduziu ao que ele nominou, a partir de Jonhn Rawls, de overlapping consensus, isto é, um consenso abarcante de sobreposição e imperativo, uma base paradigmática de moral para a construção dos próprios direitos fundamentais numa sociedade que atualmente é marcada pela pluralidade.

Essa constatação irradiou-se como que amalgamando as interconexões das categorias de direitos humanos, como os liberais, ligados à inviolabilidade da pessoa humana e a garantia ao livre gozo de suas liberdades e do comércio num cenário de exercício de direitos democráticos que de uma forma ou de outra estão ligados à vida privada e ao sistema econômico abarcante.

E é um anseio de todo homem a garantia de igualdade social substancial, resguardo de direitos sociais sob os quais paira a proibição de retrocesso, e todos os processos de inclusão que favoreçam a inserção e participação de todos em nível de igualdade material, respeito recíproco e autonomia para exercer com equilíbrio as relações jurídicas que se põem no dia a dia e os benefícios que a sociedade tem a oferecer.

Se no passado, a pretexto do que citou-se neste trabalho, a dignidade era um valor determinante do status do homem em sociedade como assim se viu em Hobbes na sua época, na atualidade, guiada pela experiência humana no campo das violações de direitos, a dignidade ganhou lugar de destaque supremo no discurso dos direitos humanos e passou a permear as decisões judiciais, porque o recurso à proteção desta dignidade é usado por juízes não apenas para prevenir ofensas ao ser enquanto sujeito de direitos, como também, enquanto supedâneo para introduzir determinados direitos fundamentais invocados no caso concreto.

\footnotetext{
${ }^{110}$ C.f. The concept of human dignity and the realistic utopia of human rights, passim.
} 
E para mais do que isso, a transição da moral para o direito desta dignidade enquanto princípio trouxe como benefício importante o reconhecimento jurídico que ressaltou um anseio demandado pelos homens, na condição de cidadãos, guindando os mesmos um status que conferindo à condição do sujeito, à de sujeito autodeterminado garantiu a todos e não somente a alguns pertencentes a determinadas classes, a prerrogativa de invocar tal reconhecimento objetivamente nas barbas do judiciário.

E, diga-se mais, que a própria experiência das violações a dignidade da pessoa humana desempenhou uma função evolutiva, dita por Habermas como criativa, pois fomentada em cenários de desigualdade, discriminações de toda ordem, ofensas as liberdades linguísticas ou culturais, toda uma plêiade de experiências foram e vão se colmatando no contexto da humanidade e induzindo a construção de mais direitos humanos inspirados na moralidade de uma proteção da dignidade do ser em primeiro lugar.

E esse lugar de proeminência já se destaca na Declaração Universal dos Direitos Humanos de 1948 adotada pelas Nações Unidas quando já em seu preâmbulo reconhece a dignidade intrínseca de todos e os direitos iguais e inalienáveis de todos os membros da família humana. Em seu artigo $1^{\text {o }}$ deixa claro: "Todos os seres humanos nascem livres e iguais em dignidade e direitos".

E novamente o imperativo categórico de $\mathrm{Kant}^{111}$ se faz ecoar, porque traz consigo uma exigência moral ao determinar que toda pessoa jamais seja tratada como um objeto ou um meio para se alcançar um fim estatal, mesmo que em nome de um ideário coletivo. Isso significa, novamente, que o ser é um fim em si mesmo.

Claro que, apesar de ser um conceito que há muito tempo vem sendo cultivado até mesmo como um anseio da humanidade a dignidade da pessoa humana realmente

\footnotetext{
${ }^{111}$ Citado neste trabalho na fundamentação da metafísica dos costumes quanto a sua construção do homem como um fim em si mesmo
} 
ganhou relevo no contexto jurídico a partir da segunda guerra mundial ${ }^{112}$ que deixou a todos uma herança de horrores e crimes de toda ordem contra as massas europeias que foram massacradas neste período. E sem querer pecar pelo generalismo e singeleza de espírito, não se deixe de mencionar o holocausto não só de judeus, mas de toda uma gama de minorias execradas de sua existência em nome de ideais obscuros que assolaram toda Europa.

Sob este prisma a dignidade da pessoa emerge como princípio básico deste sujeito de direitos. Apesar da indeterminação deste termo 'dignidade' que tem sido alvo de inúmeras críticas, mormente em seara constitucional brasileira, o fato é que realmente a normatização de um princípio tão aberto como da dignidade da pessoa humana não pode ceder a retrocessos culturais ou mesmo a uma simplificação de seu conceito a pretexto de uma indeterminação. Pela relevância desta aquisição do sujeito de direitos a seu patrimônio pessoal, a dignidade alcança legitimidade enquanto dimensão constitucional e da aplicação direta dos princípios que dela decorrem.

Por isso mesmo, pode-se dizer que a dignidade enquanto princípio substantivo pertence a todas as pessoas e se converte num conceito normativo fundamental, sobre o qual os próprios direitos humanos podem ser deduzidos mediante situações em que as vulnerabilidades humanas despontam, e sua implementação não comporta negação deste princípio ou como quer Rodotà ${ }^{113}$ a desconsideração ou ilegitimação deste princípio para alguns que seriam indignos ou menos dignos de

\footnotetext{
${ }^{112}$ Em que pese Habermas conferir exemplo no ordenamento jurídico alemão no século XIX que já encubaria a ideia de proteção da dignidade humana como princípio abarcante, senão veja-se: na justificativa da abolição da pena de morte e do castigo corporal do § 139 da Constituição alemã de março de 1849, onde se encontra a seguinte afirmação: "Um povo livre deve respeitar a dignidade humana inclusive no caso de um criminoso."In: The concept of human dignity and the realistic utopia of human rights. Op.cit. Tradução: Menelick Carvalho Netto.

${ }^{113}$ Op.cit. p. 197
} 
expressar capacidade jurídica para alçar todo e qualquer direito fundamental que esteja à disposição do ser humano, em sua dimensão de sujeito titular de direitos.

Deduzindo o pensamento do jurista italiano citado, verdade é que a dignidade da pessoa humana se apresenta como uma nova acepção da cidadania e do próprio princípio emerge o entendimento de que a pessoa não seja o meio para instrumentar sua própria dignidade. Nesta significação a aplicação da dignidade como princípio objetivo e indutor da interconexão com os direitos fundamentais afastaria a redução da pessoa à dimensão de objeto manipulável no mercado, por exemplo, em particular quanto fonte de lucro o que toca de maneira espetacular a questão das relações privadas que envolvam a autonomia privada.

Depreendendo-se este pensamento, importante destacar neste momento a relevância da doutrina alemã ${ }^{114}$ vanguardista no desenvolvimento das teorias de direitos fundamentais e da proteção à dignidade da pessoa humana que ao conferir importância jurídica aos direitos fundamentais e objetivação do princípio da dignidade da pessoa humana, legou importante ensinamento sobre a eficácia horizontal ${ }^{115}$ dos direitos fundamentais nas relações privadas - contratuais principalmente- impondo valores a serem respeitados entre dois ou mais sujeitos na construção de um termo abarcante de um interesse não raras vezes patrimonial, calcados sempre num critério de igualdade material e equilíbrio do vínculo.

Neste aspecto, mormente pela apertada síntese que nos impele este trabalho, a autonomia privada enquanto conquista decorrente desta dimensão serve de exemplo analítico no universo das relações de direito privado, porque transcende a esfera da livre

\footnotetext{
114 Cf. BENJAMIN, Antônio Herman; MARQUES, Claudia Lima; BESSA, Leonardo Roscoe Bessa. Manual de Direito do Consumidor. 2.ed. São Paulo: Editora Revista dos Tribunais, 2009, p. 28

115 HESSE, Konrad. Temas fundamentais do Direito Constitucional, op. cit. passim
} 
contratação e liberdade de contratar, para antepor em nome desta dignidade uma tutela especial decorrente de uma ordem pública, mas também de uma moralidade social.

Daí porque neste campo das relações contratuais a constitucionalização do Direito Civil ganha especial relevância, porque demonstra claramente como a influência dos direitos fundamentais determina novos paradigmas para a validação das relações, a exemplo das citadas acima.

Assim, não basta que haja uma validade normativa da relação contratual (agente, objeto e forma - artigo 104 do CCB). É preciso considerar a dimensão da dignidade em sua acepção maior na proteção do indivíduo frente ao vínculo que está para a se formar.

Neste diapasão é que o contrato em seu núcleo que é o vínculo assumido pelas partes não pode mais ser visto com uma instituição tal e qual a que fora constituída nos vetustos tempos do direito romano e de seu já relativizado princípio da pacta sunt servanda. Isto porque as relações obrigacionais se desenvolvem num sistema de processos dinâmicos ${ }^{116}$ e atualmente voltados à instrumentalização da relação em prol de interesses mais elevados no ordenamento, tais como a justiça, a segurança, a livre iniciativa e principalmente, no que interessa para este trabalho: a preservação da dignidade da pessoa humana na relação contratual ${ }^{117}$.

Como prescreve Norberto Bobbio ${ }^{118}$ essa transição de um estruturalismo formal do contrato para um funcionalismo da relação, indicando a liberdade dos agentes circunscrita por valores superiores tal qual a dignidade da pessoa humana, denuncia que os escopos do contrato moderno são muito mais voltados à conformação com certos

\footnotetext{
${ }^{116}$ SILVA, Clovis do Couto e. A obrigação como processo. Rio de Janeiro: FGV, 2006, passim.

${ }^{117}$ ROSENVALD, Nelson. A função social do contrato. In: Direito contratual: temas atuais.

Coordenação: Giselda Maria Fernandes Novaes Hironaka e Flavio Tartuce. São Paulo: Método, 2007, p. 87 e ss

118 BOBBIO, Norberto. Dalla struttura alla funzione. Milano/IT: Edizioni di Comunità, 1984, p. 74-75
} 
anseios de caráter moral inseridos no consciente coletivo que a seu turno são tidos como bens valiosos e preservados pela sociedade.

Neste jaez, a função social à guisa de realizar o ideal da dignidade, convertese na própria ratio do negócio jurídico servindo como elemento balizador da autonomia privada, dimensionando-a para o social. Não há mais que se falar numa relação contratual calcada única e exclusivamente na construção atomística da vontade dos participantes, haja vista, a interferência de metaprincípios de ordem constitucional, não raras vezes regulados em normas infraconstitucionais que para mais que um dirigismo, exercem claramente uma controladoria em todas as fases da relação, desde sua construção até o momento pós-executório do contrato.

Portanto, ao se olhar a boa-fé como elemento intrínseco inarredável do contrato, mormente em seu aspecto objetivo, o que se vê é justamente um standard ético controlador do comportamento dos agentes, voltando-os de seus interesses egoísticos na relação, para valores maiores como a lealdade, a cooperação, a proteção da dignidade do alter, submetendo toda e qualquer relação ao império de direitos fundamentais e o respeito á dignidade como valor maior.

Isso fica claríssimo, também, nas normas trabalhistas que vigoram sob a batuta dos direitos sociais do trabalhador mas não olvidam da necessidade de irredutibilidade do trabalhador a ferramenta à disposição do empregador em nome não do contrato entre as partes, mas de uma moral social calcada na proteção da boa-fé objetiva das partes, submetendo o conteúdo de sua autonomia privada à obediência à normas públicas porque advindas de um contexto constitucional que, a despeito de qualquer discussão da validade normativa do negócio jurídico, podem eivá-lo de invalidade se carente de bases mantenedoras da dignidade do trabalhador que é eixo interrelacional para aplicação de uma gama de direitos fundamentais de ordem social trabalhista. 
$\mathrm{Na}$ esfera econômica, noutra ilustração, apesar das críticas quanto a uma suposta ordem moral opressiva do mercado, um processo de colonização, a verdade é que a incidência não só dos princípios diretos da ordem econômica e financeira traz à baila a influência do princípio nas relações creditícias individuais ou coletivas de modo a assegurar a proteção à pessoa humana. Aqui o microssistema de direitos do consumidor serve de amparo por sua alta sensibilidade ao princípio da dignidade e a proteção do consumidor enquanto indivíduo e enquanto titular de direitos metaindividuais.

Note-se aqui, desde já, a importância do ordenamento constitucional brasileiro ao reconhecer a este sujeito de direitos, individual ou coletivamente, o direito fundamental de ser protegido (artigo $5^{\circ}$, XXXII da CFB) em sua posição de vulnerabilidade e hipossuficiência no seio das relações contratuais com aquele considerado hipersuficiente, elevando a proteção à esfera de um princípio geral dentro da ordem econômica, onde vale a pena repetir o texto normativo:

A ordem econômica, fundada na valorização do trabalho humano e na livre iniciativa, tem por fim assegurar a todos existência digna, conforme os ditames da justiça social, observados os seguintes princípios (...) V- defesa do consumidor; (...)

Em meio ainda à norma civil contratual a própria aplicação da cláusula rebus sic stantibus, a exceptio non adimpleti contractus permeados por valores ligados à preservação da dignidade das partes na relação, são demonstrativos da controlabilidade de normas constitucionais na esfera do equilíbrio material entre os sujeitos integrantes da relação contratual frente à ordem econômica, visando sempre a garantia da dignidade das partes que a constroem, pela autonomia privada, negócio jurídico calcado em intersubjetividade, porém, ladeada pelo respeito a preceitos fundamentais e validativos da relação, e principalmente a dignidade da pessoa humana. 
Então, pelo escore da análise até aqui, inclusive com a observância dos exemplos analíticos citados, o que se nota é uma influência do sistema constitucional na manutenção do equilíbrio entre as relações do sistema social e suas relações privadas internas e o sistema econômico, que estão sempre em tensão.

Rodotà $^{119}$ cita a norma constitucional italiana em seu artigo 41 - usada meramente como ilustração e contraponto- que institui a iniciativa econômica privada de

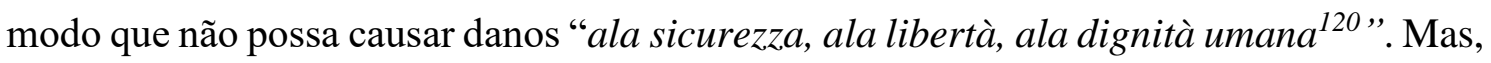
isso só não basta para explicar, porque um dos fundamentos da República Federativa do Brasil é a dignidade da pessoa humana, que deve ser entendido em sua amplitude máxima.

De fato, neste ponto, a construção do homus dignus só tem efetividade quando considera a própria pessoa que é o ponto de fundamental deste conceito chamado de indeterminado em plano de eficácia horizontal. Assim, no seio de uma relação privada norteada pelo Direito Civil o conceito de dignidade não é indeterminado, mas antes determinado porque se conduz pela autodeterminação, o respeito e a proteção desta pessoa em todos os níveis guiado por preceitos oriundos do sistema constitucional objetivamente considerado. Translada-se em direito fundamental indissociável deste sujeito de onde emanam outros dele, frisando-se, a construção da autonomia privada, o controle da economia, a saúde, educação, e tantos outros que por fim se ligam ao princípio matriz.

Sob este aspecto a dignidade é um metaprincípio que influencia diretamente o ordenamento civil transformando profundamente todos os seus paradigmas vetustos e em parte obsoletos servindo como eixo fundante desta inter-relação entre o sistema civil e constitucional.

\footnotetext{
119 Op. Cit, passim.

${ }^{120}$ A segurança, liberdade e dignidade humana (tradução livre).
} 
Pensar o Direito Civil sob este prisma importa em rever dentro de seu sistema interno antigos princípios determinantes para transportá-los à nova realidade e as novas expectativas congruentes construídas no bojo do sistema jurídico, para então aliá-los à pessoa partindo da concepção de que sua expressão se dará por esta metanorma (dignidade) como diretriz de validade e legitimidade dessas expectativas. É uma tarefa árdua que este humilde trabalho nem de longe pretende realizar.

Mas, os indicativos das mudanças ocorridas denunciam que o discurso vazio de uma constitucionalização do Direito Civil é falso a partir do momento em que apenas indicamos o processo sem demonstrá-lo. Daí porque a (re) construção da norma civil, frente ao ordenamento constitucional, antes de ser mera adequação à realidade da Constituição é adequação de um lado à realidade comunicacional do sistema jurídico por via da Constituição e de outro lado à realidade da pessoa enquanto indivíduo (sujeito de direitos) e coletividade (destinatária da comunicação) tendo aí como mote desta adequação os direitos e garantias fundamentais, a partir da dignidade da pessoa humana como valor moral fundante e inarredável.

Sob a égide deste princípio se soerguerá o Direito civil moderno, em que pese não desconhecermos a existência de outros pontos de toque entre o sistema constitucional, sobre os quais não se debruçará a análise deste trabalho pela amplitude do objeto. 


\section{POR UM DIREITO CIVIL CONSTITUCIONAL NA ÉGIDE DA PESSOA HUMANA}

Neste capítulo a pretensão é de contextualizar e relacionar toda a temática que até o presente momento veio sendo descrita com os esforços voltados a lhe dar alguma concretização no seio da norma civil. A par de determinar a transição de um Direito Civil puramente dogmático para um Direito Civil Constitucionalizado, de se ver que a tarefa não foi e nem é das mais fáceis, salvo o reducionismo mecanicista da mera subsunção da ordem civil em face de sua submissão hierárquica - como muitos asseveram ao ordenamento constitucional.

De fato, nos pareceu plausível a concepção da teoria sistêmica em Luhmann para determinar os escopos das relações comunicacionais entre sistemas jurídicos em planos abstratos e superiores cujos resultados num primeiro momento afastariam o componente subjetivo, ou seja, o social, para culminar num processo autopoiético de abertura e fechamento em que os sistemas em comunicação buscariam restabilizar expectativas tidas como congruentes e que claramente se voltariam para o próprio contexto social num momento posterior de fixação.

Se fosse possível observar o arquétipo demonstrado até aqui talvez pudessem ser vistas pontes de interligação entre ordens jurídicas diversas num primeiro momento comunicando-se com a Constituição do Estado que atuaria como um filtro de tais irritações ${ }^{121}$ e influências de outros sistemas autônomos de comunicação, agindo como instancia autônoma e em ação de reciprocidade, aprendizado e intercâmbio de experiências recebidas e enviadas em face de racionalidades múltiplas.

${ }^{121}$ Cf. NEVES, Transconstitucionalismo, op.cit. p.62 e ss. Principalmente, quando utiliza a expressão "pontes de transição" 
Num primeiro momento essa Constituição funciona realmente como uma ponte de transição, conforme citado da obra do professor Neves para estabelecer uma relação institucional e interna entre direito e política para a realização, mormente, de um princípio de igualdade $^{122}$ para garantia da democracia. E claro, sem que haja esta igualdade, sequer poder-se-ia falar em democracia o que fatalmente seria um retrocesso à própria idealização da dignidade da pessoa humana.

Mas, para além dessa concepção de uma ordem interna acoplada estruturalmente, essa transversalidade constitucional supera as fronteiras do Estado, lançando-se no cenário internacional de ordens jurídicas transnacionais e supranacionais, que carregam consigo uma gama de problemas ligados à diferenciação social no plano internacional, comércio, segurança, meio ambiente e a realização de direitos humanos. Tal observação, em que pese não ter sido alvo deste trabalho, pressupõe-se, pois que, tratamos de um processo comunicacional já em face de sistemas internos para releitura do que se convencionou chamar Direito Civil-Constitucional.

E torna-se inegável o fato de que atualmente os problemas que afrontam a humanidade não podem e não são departamentalizados por ordens jurídicas internas fechadas em si mesmas. Existe, ao que tudo indica, um entrelaçamento de ordens jurídicas

\footnotetext{
${ }^{122}$ Talvez aqui sejam eficazes as palavras de Dworkin quanto a questão filosófica da igualdade, porque ao longo do trabalho ao nos debruçarmos sobre os conceitos de uma igualdade substancial, sempre nos referimos à uma igualdade ligada à prospecção de valores e princípios constitucionais em constante evolução, sem olvidar a igualdade formal. Dworkin, fala de dois princípios conjugados para a determinação da igualdade. O princípio da igual importância na visão do autor como um dever moral de atuação para o benefício da coletividade, formalizando relações em equilíbrio de considerações. Já o princípio do individualismo ético trata das escolhas individuais num contexto social. Assim, a igualdade pressuporia uma união dos dois princípios onde no primeiro o governo adote não só políticas como um ordenamento voltado para garantia de acesso e inclusão de todos independentemente de suas qualidades individuais. Já pelo segundo princípio denota que este mesmo governo adote medidas em igual extensão que apoiem as decisões eticamente aceitáveis de cada um, por via de políticas públicas e normas capazes de garantia, em nosso sentir, a implementação de preceitos fundamentais e a preservação da dignidade de todos, fazendo aqui uma extensão do pensamento deste autor. Há na obra de Dworkin uma ideia de igualdade voltada para o bem-estar muito mais ligados ao que o Direito brasileiro entende por isonomia. Seja como for, é em amplo sentido uma igualdade substancial. (DWORKIN, Ronald. A virtude soberana: a teoria e prática da igualdade. Tradução: Jussara Simões; revisão técnica e da tradução Cícero Araújo, Luiz Moreira. 2.ed. São Paulo: Editora WMF Martins Fontes, 2011, passim.)
} 
com o escopo de buscar por via das experiências acumuladas cultivar valores, princípios e normas comuns, na busca da realização de ideais que agora se encontram numa verdadeira vila global.

Trabalhar este conceito, importa em entender que num plano abstrato e superior ao plano do sujeito, existe uma comunicação além das fronteiras do próprio Estado, em uma dimensão absolutamente superior onde trafegam discussões que giram essencialmente em torno de questões múltiplas, mas que certamente perpassam a todo instante a esfera do homem enquanto razão para existência de qualquer discussão, já que, os sistemas não podem se recriar apenas para sustentar a abstração de seus preceitos.

Não foi e nem é escopo deste trabalho delinear a transversalidade ou o transconstitucionalismo mesmo diante de uma sociedade mundial pluralista e hipercomplexa, que constantemente converge tal complexidade em valores culturais canalizados para o seio interno da sociedade num país. Mas, seria impossível afastar ainda que superficialmente esta ideia, porque de fato o substancialismo constitucional e sua evolução constante e irrefreável passa por este momento até se chegar ao plano de comunicação com sistemas internos, como é o Direito Civil e Constitucional.

Por isso a escolha da teoria dos sistemas em Luhmann veio com intuito de denunciar que estas construções de racionalidades constitucionais transversas criam, pelas irritações recíprocas que os sistemas de ordens jurídicas diversas se causam, um intercâmbio contínuo que se irradia para o sistema interno.

Porque não se trata aqui simplesmente de aplicação de uma ligação hierárquica entre o sistema constitucional que atua como limitador da norma interna, e o sistema civil que se submete aos limites constitucionais, tendo sua legitimidade guindada ao mero status de conformação com os interesses constitucionais. 
Daí porque, neste viés, apesar de não nos cumprir tecer críticas superficiais, seja como for, afasta-se dos preceitos apregoados até aqui a ideia verticalizadora das relações de Direito Constitucional e Direito Civil, apregoada por Pietro Perlingieri, ${ }^{123}$ posto que, coloca a questão como uma harmonização coerente e razoável segundo critérios hermenêuticos de adequação e proporcionalidade afastando, neste plano interpretativo, ilusões de objetividade dos textos civis em sua interpretação meramente literal.

A redução da questão a uma interpretação evolutiva da norma civil, significa na ideia deste grande autor, modificar-se no plano dos valores éticos a temática civilística para uma releitura que deixa na mão do exegeta a tarefa dupla de asserção dos princípios constitucionais aplicando-os em relações individuais para justificação da norma civil.

Sob este enfoque as normas constitucionais seriam aplicadas de forma indireta, e não apenas sob o comando de mera subsunção. Em que pese o autor se esforçar para não estabelecer uma conexão de subsidiariedade da norma constitucional em face da norma ordinária civil, de fato trata-se de luta inglória, porque afasta-se da problematização que aqui tentamos demonstrar, onde a realidade constitucional não é ordinária, mas substantiva e em movimento constante e de velocidade muito grande, diante da própria hipercomplexidade social e os processos de comunicação transversa com outros ordenamentos.

Seguindo esta esteira o Direito Civil em face da comunicação contínua com o sistema constitucional embarca em mesmo trilho e segue uma tendência de reconstrução normativa e não só interpretativa, para conformar-se ao ideal constitucional prospectivo.

Daí porque, a tão criticada codificação, como ocorreu nalguns ordenamentos, tal qual o brasileiro, mas que hodiernamente e em vários aspectos transcenderam as

${ }^{123}$ Cf O Direito Civil na legalidade Constitucional. Op.cit. p. 571 e ss 
normas civis de princípios vetustos, para uma adequação à realidade dos valores sociais determinantes num contexto de policontexturalidade e complexidade muito grandes. Mais do que um exercício de hermenêutica, trata-se de vinculação por via da comunicação sistêmica, em que expectativas congruentes vão se restabilizando no plano interno do sistema jurídico buscando resistência e adequação frente a valores cultivados no seio do sistema social, sem olvidar da comunicação em nível superior de ordens jurídicas transversas.

Neste viés, a norma civil não apenas é interpretada à luz da Constituição. Ela é reconstruída, muitas das vezes desconstruindo princípios muito antigos e regras engessadas pelos tais, para dar o mesmo caráter substancial à norma civil, resultante de sua constante operação comunicacional de fechamento e abertura em face do sistema constitucional.

São vários os exemplos, como a nova teoria dos direitos de personalidade ligados a direitos fundamentais e consequentemente à dignidade como valor fundante, a eticidade em face da boa-fé objetiva, a inserção das usucapiões constitucionais no contexto do código, a adequação de institutos do direito de família à nova realidade das famílias plúrimas e homoafetivas, merecendo destaque nesta exemplificação o novo estatuto da pessoa com deficiência (lei $13.146 / 15)^{124}$ que alterou a regulação dos absolutamente incapazes, buscando inserí-los no contexto social, em prol de sua dignidade, dentre outros.

E neste ponto da dignidade é que a importância de todo o estudo do sujeito de direitos inserido neste momento histórico-cultural da modernidade ressalta e se mostra absolutamente necessária, porque é em razão deste sujeito que o próprio Estado se funda.

124 BRASIL. Lei 13.146 de 6 de julho de 2015. Institui a Lei Brasileira de Inclusão da Pessoa com deficiência (Estatuto da Pessoa com deficiência). DOU de 07.07.2015 
A dignidade da pessoa humana enquanto um valor cultivado no contexto da sociedade humana hipercomplexas, converte-se no ponto central do fundamento da norma civil e não somente numa pedra de toque entre a conversação das normas constitucionais e o sistema jurídico interno, principalmente o sistema civil. Fica evidente, pela racionalidade que aqui se constrói que em prol da preservação deste pináculo de nossa República a própria norma se reconstrói, seja pela implementação de direitos fundamentais em seu seio, seja pelo próprio reconhecimento da necessidade de proteção desta dignidade, como no exemplo do estatuto da pessoa com deficiência que visa sua total inclusão.

Assim a transição do direito civil, para um Direito Civil Constitucional, necessariamente perpassa por esta ponte de transição que é a dignidade. Obviamente, que não a elencamos como a única dessas pontes, porque em matéria de um processo comunicacional, a tendência na complexidade é de haver mais contingenciamento e mais seleção e variação, o que importaria na criação de várias pontes de transição sob o pálio de outros princípios.

Todavia, ao reconhecermos a dignidade como valor fundante supremo de toda uma ordem de direitos e garantias fundamentais, damos a ele importância grandiosa, daí que, num corte dentro deste universo de possibilidades de discussão, este trabalho se preocupou em delinear este metaprincípio que é, em nosso sentir, a concretude do ser humano enquanto sujeito de direitos, destinatário de qualquer resultante dos processos de comunicação.

A tópica surge em último estágio vinculada ao problema (aporia) em concreto. $\mathrm{O}$ resultado da norma civil agora impregnada pelas prospecções normativas constitucionais será então, o da adequação por via de uma proporcionalidade e 
razoabilidade da proposição a ser utilizada o que não necessariamente gerará uma resposta configurada e estanque ao problema.

E antes que se diga que se trata de mera subsunção, a questão passa ao largo para dimensionar a tópica em relação à teoria dos sistemas $^{125}$, justamente porque os sistemas em seus processos comunicacionais de fechamento e abertura, vão selecionar e restabilizar expectativas congruentes e desviantes. São questões que vão se colocar ao longo do desenvolvimento do próprio processo comunicacional. A congruência reside no fato de que a expectativa encontrou elementos de resistência no sistema, adequação não só valorativa, mas normativa o que de pronto exclui aquelas que desviantes não se adequaram aos preceitos do sistema social.

...o modo de pensar sistemático procede do todo e a concepção que tem deste todo é nele predominante. Um ponto de vista vem adotado desde o princípio da investigação e a partir dele os problemas são selecionados. Os problemas cujo conteúdo concilia-se com o ponto de vista são, então, assumidos ou aceitos, e os que não se adaptam são rejeitados como questões falsamente colocadas. Toma-se de modo prévio, dessa forma, uma decisão sobre os limites dento dos quais será possível a solução dos problemas $^{126}$.

Sob estes aspectos, a tópica inicia-se da assertiva de que a forma de se pensar por problemas parte de um resultado operativo de comunicação do próprio sistema, valendo lembrar que para esse pensamento a criação de topoi admite de antemão que não há que se falar em uma concepção pronta e acabada de sistema, justamente porque este reside em uma ordem superior que está em constante determinação por suas operações de fechamento e abertura constantes.

${ }^{125}$ Cf. ROESLER, op.cit. p.134 e ss

126 Idem, ibidem. 
Em que pese sabermos que Theodor Wiehweg propôs críticas à relação entre a tópica e os sistemas, de qualquer modo em seu pensamento ele próprio compreende essas ligações importantes.

Dessa forma o Direito Civil projeta-se com seu conjunto de normas a uma dimensão evolutiva tal qual o sistema constitucional, porque enquanto participante dos processos de comunicação, sua evolução é constante o que alcança diretamente o contexto das relações privadas que são o alvo final de toda construção sistemática do Direito Civil.

Se consideramos a função dos topoi para orientação do pensamento na busca de solução de problemas, então a reavaliação de premissas é de sua essência. Daí porque sua relação com a jurisprudência faz todo sentido.

E os problemas em seara civil são um dado constante e não patente de eliminação porque atrelados às relações subjetivas e intersubjetivas que se tornam cada vez mais complexas à medida da complexidade da própria sociedade.

Assim, a performance de decisões em seara Civil converge-se inevitavelmente para paradigmas constitucionais que impulsionam o pensamento jurisdicional em diversas situações, que por sua vez, movimentam a jurisprudência no seu sentido evolutivo. Desta sorte, a dignidade da pessoa humana transforma-se no fundamento de qualquer premissa que pretenda construir na solução de um problema em Direito Civil (topoi).

Daí passa a fazer todo sentido sua reconstrução para adequação constante aos preceitos normativos do sistema constitucional, não só por via de decisões jurisprudenciais, como também, no âmago de sua estrutura normativa.

A reflexão filosófica constante de questões sociais e jurídicas que se repetem e ao mesmo tempo se complexificam mais, traz à tona a necessidade de revisão constante do pensamento civil em prol do pensamento constitucional influenciador e vinculador. 
Essa interlocução se dá por pontes de transição e a dignidade, repetimos, é a principal delas.

Recuperando um dos exemplos citados acima, nos dias atuais não há como se conceber a existência da pessoa com deficiência de qualquer ordem dentro de um conceito de exclusão, mas antes de inclusão e igualdade substancial, com garantia a uma série de direitos fundamentais elencados no seio da novel lei $13.146 / 15$, tendo por base a Convenção sobre os Direitos das Pessoas com deficiência e seu Protocolo facultativo, ratificada pelo Congresso Nacional por via do Decreto Legislativo $\mathrm{n}^{\circ} 186$, de 9 de julho de 2008 , em conformidade com o procedimento previsto no $\$ 3^{\circ}$ do artigo $5^{\circ}$ da Constituição Federal do Brasil- que dentre os vários aspectos abordados, assegura à pessoa com deficiência o direito de exercício de sua capacidade legal em igualdade de condições com as demais pessoas, sendo a medida de curatela e interdição agora uma medida excepcional e extraordinária vista como medida protetiva e proporcional ás necessidades extremas desta pessoa e pelo menor tempo possível.

Daí que na solução de problemas relacionados à participação deste sujeito em cenários que envolvam relações jurídicas privadas, afastam de plano qualquer pensamento de invalidade, incapacidade deduzida ou interdição absoluta, para antes perpassar a relação por seus resultados jurídicos e avaliar se tal sujeito, apesar de suas necessidades, poderia ou não discernir o ato jurídico tal e qual o homus medius em mesma situação.

No bojo desta mesma norma, podemos ainda citar uma série de preceitos fundamentais concretizados em prol da pessoa com deficiência, fundados num processo de inclusão e proteção de sua cidadania e dignidade, que seriam: a não discriminação, atendimento prioritário, direito à vida, à saúde, direito à habilitação e reabilitação, educação em sistema educacional inclusivo, moradia, direito ao trabalho e a habilitação 
e reabilitação profissional, cultura, lazer, esporte, previdência social e outros elencados na Lei.

E citamos esse exemplo inicial, de evolução constitucional do Direito Civil, que culminou na revogação de vários artigos, mormente, do artigo $3^{\circ}$ do Código Civil Brasileiro, abandonando a retrógrada concepção do absolutamente incapaz por enfermidade mental, ou deficiência, enquanto pessoa a ser excluída dos atos da vida civil.

Todavia, este movimento por uma racionalidade constitucional do Direito Civil não é de agora. Esta Lei representa um passo adiante, mas não é o primeiro e nem será o último. Na verdade expressa em seu fator de discrimen normativo um grupo de pessoas, sujeitos de direitos, que por sua condição são alçados ao patamar protetivo de seus direitos e garantias fundamentais afastando repulsivas ideologias de segregação, exclusão e discriminação, que outrora eram incentivadas pela exegese da própria lei civil, ainda engessada em sua estrutura codificada.

Nos próximos segmentos deste capítulo, buscaremos demonstrar processos anteriores de transição do Direito Civil que já demonstram em sua construção a influência de processos de estabilização de expectativas a partir do incremento de valores e princípios internalizados a partir da evolução da dimensão humana, dentro dos aspectos que estão sendo defendidos no pensamento desenvolvido neste trabalho.

\subsection{Por um Direito Civil-Constitucional: A função social da propriedade e seu incremento no sistema jurídico brasileiro}

A sociedade humana sempre se firmou sobre uma estrutura baseada em sustentáculos erigidos para garantirem a continuidade de sua existência e a segurança de 
suas relações ${ }^{127}$. Não é exagero afirmar que o Direito de propriedade, enquanto um direito subjetivo sempre se constituiu como o valor mais caro sobe o aspecto das aquisições patrimoniais do homem numa acepção individualista ou coletiva e, sobretudo, num modelo liberal.

Sob este enfoque, a propriedade sempre representou um símbolo de prosperidade, liberdade e, obviamente, prosperidade o que inegavelmente a erigiu como um símbolo máximo da própria dignidade da pessoa humana ${ }^{128}$.

Ostentar a propriedade é para o homem, como ostentar sua própria existência no mundo da vida, determinar a si próprio como alguém portador de um símbolo de resistência, libertação e inclusão social. Daí porque, o homem e sua propriedade significam um homem dignificado, transformado de seu estado de natureza bruta, para um ente social capaz de albergar em seu seio, não somente seu núcleo familiar, como também, conduzir-se em comunidade em mesmo nível daqueles que ostentam igual símbolo.

Desta feita, a propriedade torna-se enquanto fato jurídico, um direito absoluto, imprescritível, defensável erga omnes, fortalecido pelas contingências e lutas que no correr da história solidificaram o instituto para o tornarem parte indissociável da própria existência da sociedade. Uma sociedade que não comunga em seu mais básico

${ }^{127}$ Santos Justo lembra que os em Roma os jurisconsultos não elaboraram um modelo de propriedade caracterizado como um instituto jurídico formulado e acabado. Daí que enfrentaram muitas dificuldades pela densidade do conteúdo do conceito de propriedade. Preferiam a utilização de um conceito de disponibilização da coisa aos cidadãos a partir dos territórios conquistados. No início, a mancupium ou mancipium designando um direito potestativo sobre pessoas e coisas; depois nos últimos anos da República, o dominium para designar o poder ou faculdade do proprietário; finalmente prevaleceu na condensação de Justiniano, proprietas, acentuando a pertença absoluta da res. Na Idade Média os glosadores, com base no Corpus Iuris Civilis, deram definição à propriedade como o ius utendi et abutendi re sua, evidenciando o direito de usar e abusar (gozar) da coisa da forma e modo que o proprietário quisesse, consequentemente anunciando uma ideia ainda embrionária e distante da função econômica e social do termo. SANTOS JUSTO, Antonio. Direito Privado Romano (Direitos Reais). Coimbra/PT: Coimbra Editora, Boletim da Faculdade de Direito da Universidade de Coimbra, 2014, p. 16 e ss

${ }^{128}$ TEPEDINO, Gustavo; SCHREIBER, Anderson. A Garantia da propriedade no Direito Brasileiro. In: Revista da Faculdade de Direito de Campos, Ano VI, n.6, julho/2005, p.117 
entendimento deste conceito, sequer pode ser comparada a uma tribo, que por mais comunitarista que seja, ainda assim, respeita a dignidade de seus pares no que tange aos seus valores caros e a eles e, somente a eles pertencentes. Seria um retorno ao egoísmo anterior à própria vida em sociedade.

Mas, ainda assim, conforme ressalta professor Olindo ${ }^{129}$ em primorosa tese, imperioso lembrar que a base histórica do absolutismo, num período de oposição do Estado ao indivíduo, pôs em xeque o binômio autoridade/liberdade, determinando a propriedade numa dimensão negativa ao seu sentido valorativo, num momento de nossa história em que as lutas pela superação do poder abarcante do príncipe eram uma necessidade inafastável para uma sociedade que rompia os paradigmas da época à custa de sangue das revoluções sequenciais.

Neste caminho, vale destacar importante trecho do Code Civil napoleônico, que evidencia a importância da inserção do conceito de propriedade como um dos dogmas do liberalismo inserindo-a como um valor, uma ideologia protetiva do ser e assecuratória de seu direito individual não só de posse, mas, principalmente, de propriedade. Trata-se de uma resposta revolucionária em contraposição ao absolutismo e as constantes tentativas do sistema feudal de concentrar o poder em si e das propriedades a uma nobreza decadente.

Art. 544- La propriété est le droit de jouir et disposer des choses de la manière la plus absolue, pourvu qu'on n'em fasse pas um usage prohíbe par les lois ou par les règlements. ${ }^{130}$

129 MENEZES, Olindo Herculano. Perfil da propriedade contemporânea (Destaque da propriedade fundiária). 2009. 517f. Tese (Doutorado em Direito). Departamento de Pós-graduação da Faculdade de Direito, Universidade de Brasília, Brasília/DF, 2009. Citado às p. 272 e ss.

${ }^{130}$ FRANÇA. Code Civil. 111.édition. Paris/Fr: Éditions DALLOZ, 2012. O Direito de gozar e dispor das coisas de forma mais absoluta, desde que não se faça delas um uso proibido pelas leis ou regulamentos (tradução livre) 
Assim, a partir deste resgate na Europa de um princípio de propriedade privada, o seu detentor passou a gozar da liberdade plena de exercício deste direito inoponível erga omnes, perseguindo em seu favor os fins e conveniências oriundos de sua vontade e de acordo com certos limites impostos por regras de convivência e obrigações de caráter propter rem que tem o condão de regulação das relações de vizinhança.

É um começo calcado numa singularidade do princípio, porque reduz ao nível do indivíduo o exercício da plenitude de um direito subjetivo garantido a ele e incontrastável até mesmo pelo Estado, salvo em prol de um interesse público, o que de servia de regra excepcional neste e nos períodos finais do médio termo da história.

Então, neste escorço histórico brevíssimo, apesar de não haver ainda uma conotação social do princípio, o que se nota é que como chama espalhada ao vento, as ordens jurídicas pela Europa e consequentemente e posteriormente por suas colônias como os Estados Unidos e o Brasil, passaram a comungar de tais valores nascidos de ideais burgueses com o fito de garantir no fundo, a dignidade da pessoa humana, sob uma roupagem rudimentar, a nosso ver, de um direito á propriedade privada como símbolo máximo da sustentação deste ser no contexto social.

A transversalidade desses valores se deu pelo penhor de guerras, revoluções e o desenvolvimento de uma ordem constitucional que a seu passo firmaram um pensamento uníssono e congruente entre os povos ocidentais em geral, demonstrando a intensa comunicação sistemática dessas ordens políticas e jurídicas já em torno de um direito subjetivo que nasceu de um anseio íntimo dos povos de sua época.

A disseminação de um princípio voltado para a função social da propriedade, inspirado principalmente nos ideais do código de Napoleão e as normas garantidoras de direitos fundamentais do homem, como a Declaração dos Direitos do Homem e do 
Cidadão ${ }^{131}$ que preconiza em seu artigo 17 que: “Como a propriedade é um direito inviolável e sagrado, ninguém dela pode ser privado, a não ser quando a necessidade pública legalmente comprovada o exigir e sob condição de justa e prévia indenização. "

Como um primado constitucional resultante, pela ótica que desenvolvemos, de processos comunicacionais oriundos deste caminhar histórico, autores, como Eugênio Facchini Neto ${ }^{132}$ denunciam que a primeira constituição a fazer referência, mesmo indireta, a uma função social da propriedade foi a mexicana em 1917. Mas, certamente a que teve mais impacto e repercussão internacional foi a constituição de Weimar que em 1919 em seu artigo 153, na última alínea afirmava: “ a propriedade obriga. Seu uso deve igualmente ser um serviço ao bem comum". ${ }^{133}$

Interessante como, em outras ordens jurídicas como na constituição da Itália, tal preceito vem a se repetir:

La proprieta` privata e` riconosciuta e garantita dalla legge, che ne determina i modi di acquisto, di godimento e i limiti allo scopo di assicurarne la funzione sociale e di renderla accessibile a tutti. ${ }^{134}$

Entre nós, a repercussão do princípio ganhou status de norma constitucional já a partir da constituição de $1934^{135}$ que em seu artigo 113, n.17 garantiu o direito de propriedade relativizando-o, porém, em face de sua função social. Contudo, foi a partir

${ }^{131}$ FRANÇA. Declaração dos Direitos do homem e do cidadão. Texto traduzido pelo Senado Francês. Disponível em: http://www.senat.fr/lng/pt/declaration_droits_homme.html. Acesso em 16/02/2016

${ }^{132}$ Cf. Comentários à Constituição do Brasil. Op.cit. p.314 e 315. Em referência aos comentários ao artigo $5^{\circ}$, XXIII da Constituição Federal da República

${ }^{133}$ Idem, ibidem. E o autor cita o original em alemão, que aqui repetimos para mero conhecimento: Eigentum werpflichtet. Sein Gebrauch sol zugleich Dienst sei für das Gemeine Beste.

${ }^{134}$ ITALIA. Costituzione della Italia. Op.cit. art.42. A propriedade privada é reconhecida e garantida pela lei que determina seu modo de aquisição, de gozo e os limites de seus objetivos a fim de assegurar a função social e torna-la acessível a todos. (Tradução livre)

135 POLETTI, Ronaldo. Constituições Brasileiras. Volume III. Constituição de 1934. 3.ed. Brasília: Senado Federal, Subsecretaria de Edições Técnicas, 2012. “E” garantido o direito de propriedade, que não se poderá ser exercido contra o interesse social ou collectivo, na fórma que a lei determinar. A desapropriação por necessidade ou utilidade pública fár-se-á nos termos da lei, mediante prévia e justa indemnização. Em caso de perigo iminente, como guerra ou cmmoção intestina, poderão as autoridades competentes usar da propriedade particular até onde o bem publico o exija, resalvado o direito a indeminização ulterior." 
da Constituição de 1967 pela primeira vez a expressão "função social” é utilizada no texto constitucional em seu artigo $157^{136}$ asseverando uma preocupação do legislador constitucional com o andar dado não só pelo pensamento constitucional brasileiro, mas por toda um patrimônio valorativo, normativo e principiológico de caráter constitucional, com certeza a partir de ordens jurídicas internacionais, seja pela jurisprudência, pela troca de experiências obtidas ou pela internalização de seus pensamentos.

Mas de fato, na história constitucional de nosso país, a função social recebeu tratamento diferenciado porque não foi referida apenas como um princípio da ordem econômica, mas porque reposicionada no sistema constitucional perdeu seu caráter de abstração e generalidade para estabelecer-se como um primado fundamental conforme preleciona o artigo $5^{\circ}$, inciso XXIII do atual ordenamento, irradiado também em diversas outras passagens do texto constitucional como artigo 170 , III, artigo $173, \S 1^{\circ}$, inciso I, artigos 184, 185 e 186, que aqui deixamos de citar remetendo o leitor ao texto constitucional, mas não deixando de apontar o comprometimento do ordenamento atual com os valores vigentes no mundo de nossos dias.

Tanto é assim que, acentua Tepedino, ${ }^{137}$ não se tratou apenas de um acolhimento de tendências mundiais. Em nosso meio o resultado da comunicação transversa trouxe para o contexto interno do ordenamento uma objetivação do princípio da função social, justamente para garanti-la não somente como direito subjetivo, evidenciando assim uma mudança estrutural no conceito.

E essa mudança estrutural do conceito perpassa pela longa discussão sobre suposta incompatibilidade do conceito de direito subjetivo e a função social, precisamente

\footnotetext{
${ }^{136}$ CAVALCANTI, Themístocles Brandão; BRITO, Luiz Navarro de; BALEEIRO, Aliomar. Constituições Brasileiras. Volume VI. Constituição de 1967. 3.ed. Brasília: Senado Federal, Subsecretaria de Edições Técnicas, 2012. “A ordem econômica tem por fim realizar a justiça social, com base nos seguintes princípios: (...); III- função social da propriedade."

137 TEPEDINO, A garantia da propriedade no Direito Brasileiro. Op.cit. p. 104
} 
por conta da não observância de que numa visão crítica do instituto, a função social apresenta uma perspectiva dinâmica na estrutura jurídica, o que realmente a desvinculou da tradicional doutrina de que estaria limitada ao direito público, isto, é, como finalidade que incide limitando o direito subjetivo de cada um à propriedade. Desse debate, o escore final adotado na doutrina civil moderna, entende que o direito de propriedade possui intrinsecamente, a função social.

No desenvolvimento do pensamento de Rodotà, Laura Beck e Marcos Ludwig $^{138}$, explicam essa natureza intrínseca da função social como um movimento de abertura que guinda o conceito do princípio a um patamar realista. Trata-se de uma concepção sistêmica onde a função social é redimensionada e lhe dão esse condão realístico denotando sua renovação constante em face da evolução do próprio sistema constitucional, que é o que nos interessa neste trabalho.

Então, fala-se aqui de um processo de comunicação em que o movimento do sistema civil é de fechamento e abertura para o sistema jurídico, mormente o constitucional, porque a função social em nosso meio é erigida a tal patamar.

Desse modo o princípio de uma função social, veio alinhar-se com outros princípios ligados à interesses sociais, que diante desta dimensão da solidariedade acabou por induzir o entendimento de que a garantia do direito de propriedade hoje é muito mais uma garantia daquela propriedade que cumpre sua função social.

No que toca ao objeto deste trabalho, a função social da propriedade representa uma dimensão funcional do direito de propriedade. E na teoria dos sistemas, trata-se de um incremento para o surgimento de mais contingenciamento por conta da diferenciação social do sistema social. O enfoque aqui, não afasta o caráter subjetivo do

\footnotetext{
${ }^{138}$ VARELA, laura Beck; LUDWIG, Marcos de Campos. Da propriedade às propriedades: função social e reconstrução de um Direito. In: A reconstrução do direito privado: reflexos dos princípios, diretrizes e direitos fundamentais constitucionais no direito privado. São Paulo: Editora RT, 2002, p. 771 e ss.
} 
direito de propriedade para torna-la uma propriedade comum, mas, o intercâmbio entre sua face subjetiva estrutural e sua função denuncia uma preocupação do sistema jurídico em garantir ou dar resistência a este princípio incorporado a partir de relações transversas, de modo a garantir sua implementação no contexto do sistema social prospectivamente.

Esse aspecto funcional deve ser visto como uma prerrogativa que ultrapassa o indivíduo para alcançar o contexto social em face de preceitos que trafegam entre o papel que a propriedade tem que exercer em tributo ao processo evolutivo social, garantindo a sua continuidade e claro, mantendo um intenso relacionamento com o sistema econômico porque a proximidade desses dois polos é inegável.

Num outro aspecto, o princípio é limitador e condicionador do exercício do próprio direito de propriedade, muito mais a fim de evitar que seu uso implique em abusos ou decréscimo de seu papel no incremento das atividades voltadas ao bem-estar social e o incremento econômico. ${ }^{139}$

Em seu papel implementador do princípio objetivamente constitucional, o Direito Civil caminha a passos não tão largos, mas importantes no sentido de criar normas e regras que visem garantir a eficácia da função social ligada não só aos interesses sociais como sistema, mas espraiando-se pelo mundo das tutelas coletivas, abrangendo, também, direitos coletivizados.

Neste momento, entendemos conveniente citar como exemplos de concretização dessa reconstrução do Direito Civil em face do sistema constitucional as usucapiões constitucionais principalmente as modalidades descritas nos artigos 183 (a usucapião pro misero) e 191 (usucapião pro labore) da Constituição Federal, que foram inseridos em texto infraconstitucional, mormente, nos artigos 1239 do atual Código Civil

${ }^{139}$ LÔBO, Paulo Luiz Netto. Constitucionalização do Direito Civil. In: Revista de Informação LegislativaSenado Federal, n.141, janeiro/março, 1999, p. 110. 
e na Lei 10.257/01 (Estatuto das Cidades) em seus artigos $9^{\circ}$ e 10, este último inovando com instituição de uma usucapião coletiva.

No primeiro exemplo, a dicção contida na norma constitucional preconiza a proteção da dignidade daqueles possuidores que pelo prazo normativo mantêm-se na coisa sem oposição utilizando-a para sua moradia em área que não ultrapasse duzentos e cinquenta metros quadrados. Tal norma repetida in totum no artigo 1239 do Codex Civil, ressalta a própria estruturação constitucional do Direito Civil ao introduzir esta modalidade de viés estritamente humanista e voltada à proteção da dignidade e direito à moradia de uma população em condições de vulnerabilidade social.

Vê-se notadamente que a norma civil para além dos requisitos de tempo, abandono da coisa que são resquícios romanos da norma, avança no sentido de acobertar uma parcela da população que inserida num contexto latente de políticas públicas habitacionais, por uma causa qualquer, estabeleça posse mansa e pacífica para fins de garantir sua moradia e consequente subsistência.

Num raciocínio a contrario sensu pode-se observar que a concessão de usucapião nessas condições não se dá somente pelo preenchimento dos requisitos formais, mas num aprofundamento do conceito de abandono da coisa, o legislador civil abarca, a partir do metaprincípio da preservação da dignidade da pessoa humana, a obrigação de conceder o direito a quem insere-se dentro de um contexto de atuação perante uma pretensa relação de direito real com escopo de realização de uma função social que o proprietário em si não atendeu, deixando as obrigações propter rem e demais encargos ao possuidor que por uma necessidade faz daquele lugar sua morada a fim de evitar a indignidade de viver sem teto.

Ora, se observado com cuidado o fenômeno representa uma prospecção da norma civil, no sentido de incrementar os elementos da usucapião a fim de adequá-los às 
expectativas absorvidas pelo sistema constitucional e restabilizadas, após o processo comunicacional com o sistema civil. Não é mero exercício hermenêutico, mas antes, reconstrução de preceitos a partir de um paradigma evoluído dentro do contexto constitucional.

Tendo por eixo fundante a dignidade, o Direito Civil elevou a patamar superior aos próprios requisitos formais do instituto, direitos fundamentais, como a moradia e o mínimo existencial da pessoa humana.

Repare-se que neste processo em plano abstrato existe a incorporação de valores e princípios a partir de relações transversas com outros ordenamentos ou pensamentos jurídicos. Neste momento o componente subjetivo é afastado para que o processo de comunicação transcorra pelos elementos já delineados nos capítulos anteriores, para após a estabilização ser ou não incorporado pelo sistema social que é o destinatário final do pensamento. Por esses motivos, admitindo-se a solidariedade como dimensão atual, comportamentos desviantes que não atendam a expectativas solidárias e humanas, provavelmente não encontrarão resistência e eficácia no contexto social, sendo então descartados em face da operação de comunicação, usando aqui termos simples para designar o processo, apesar de reafirmarmos que se trata de um processo onde o improvável é a tônica.

Em mesma esteira andou a Lei 10.257/01 (Estatuto das Cidades) ao incorporar em seu artigo $9^{\circ}$ os mesmos preceitos do artigo 183, a fim de fazer valer um de seus escopos que é o desenvolvimento sustentável das cidades à guisa dos mesmos valores já delineados acima, com o mesmo eixo fundante que é a dignidade da pessoa humana.

A inovação fica por conta do artigo 10 do mesmo diploma ao consagrar a usucapião coletiva de áreas maiores que duzentos e cinquenta metros quadrados. O intuito 
da Lei é atingir populações de baixa renda que coletivamente possuam a área para sua moradia.

Aqui o legislador civil, mesmo em lei esparsa amplia o alcance da norma referente à usucapião em razão do fenômeno demográfico de nossos dias, aliado às conurbações desorganizadas e muitas vezes desenvolvidas à custa de invasões por grupos de pessoas, verdadeiras turbas, que a pretexto de alçarem alguma dignidade montam em áreas pertentes a outrem, suas moradias e ali se fixando pelo prazo legal, são beneficiadas pela prescrição aquisitiva, aliada à proteção de direitos fundamentais, já citados, que lhes servem de amparo.

Em mesmo tom, chama atenção a expropriação contida no artigo $1228, \S 4^{\text {o140 }}$ do diploma civil, porque trata-se de situação inovadora considerada por vários estudiosos do Direito Civil como verdadeira desapropriação indireta, não dependente de iniciativa do poder público, mas por um processo e decisão judicial.

Para além das críticas da praticidade deste dispositivo, mormente, pela exigência de pagamento de indenização ao proprietário (que a regra não define por quem deva ser paga e ao mesmo tempo se destina a populações de baixa renda) o fato é que mais uma vez a norma civil paradigmada em preceitos constitucionais considera a função social da propriedade como o parâmetro principal de análise da concessão dessa modalidade de expropriação, deixando sob a responsabilidade dos possuidores darem à coisa destinação que vise o progresso social e o desenvolvimento desta mesma sociedade.

Salta aos olhos a vinculação desta norma ao aspecto econômico que deva ser dado à propriedade para o crescimento não só deste considerável número de pessoas que

140 BRASIL. Lei 10406 de 10 de janeiro de 2002. Institui o Código Civil. DOU de 11.1.2002. " O proprietário também pode ser privado da coisa se o imóvel reivindicado consistir em extensa área, na posse ininterrupta e de boa-fé, por mais de cinco anos, de considerável número de pessoas, e estas nela houverem realizado, em conjunto ou separadamente, obras e serviços considerados pelo juiz de interesse social e econômico relevante. 
possuem a área, como também, o incremento da produtividade e geração de riquezas para a sociedade como um todo.

De se ver, que pelo patamar em que se encontra o pensamento jurídico quanto a propriedade, a garantia subjetiva deste direito não pode ser tida como absoluta quando não atenda a sua função social, ou seja, não se coadune com os interesses do sistema social.

No plano concreto, já invocando a tópica para o desafio de se resolver os problemas que se colocam diante dos operadores do Direito, principalmente, em sua atividade de prestação jurisdicional, o papel do Judiciário reveste-se de grande responsabilidade e envergadura para entender sob o prisma desta concepção CivilConstitucional da função social da propriedade, quais seriam os alcances e limites do princípio em cada caso.

Tepedino $^{141}$ ressalta que o Superior Tribunal de Justiça em decisões envolvendo hospitais particulares, decidiu que os tais devem atender à função social representada por seu mister de garantir, em face do interesse geral, a saúde a todos e o trabalho, portanto, estariam compelidos a aceitar o ingresso de médicos e a internação de seus respectivos pacientes ainda que tais médicos não componham seu quadro clínico:

(...) Daí que a sentença, baseando-se na função social da propriedade, e se louvando igualmente, no particular, em prestigiosa doutrina, deu à espécie, a meu sentir correta solução. Com efeito, no caso de internamento de pacientes, existe interesse maior (do próprio paciente e de seu médico), e olhem que a saúde é direito de todos embora seja dever do Estado, interesse que nem sempre há de coincidir com o do proprietário do hospital privado. (...) o direito aqui nestes autos proclamado não se choca com o direito de propriedade, pois este, em sentido de um direito, é um direito sujeito a limitações, ou, noutras palavras, a propriedade é privada, mas sua função é social. ${ }^{142}$

\footnotetext{
141 TEPEDINO, Op.cit. p. 107 e ss

${ }^{142}$ BRASIL. Superior Tribunal de Justiça. Recurso Especial n ${ }^{\circ}$ 27.039-3/SP. Rel. Ministro Nilson Naves, Julgado em 8 de novembro de 1993.
} 
Em outro Julgamento também proferido perante a Corte Superior de Justiça, é primorosa a consideração do princípio da função social em face da aplicabilidade de um preceito teleológico dos fins da norma constitucional, que aqui com as devidas vênias, tomamos a liberdade de citar o acórdão no corpo deste trabalho:

1. (...).

2. (...)

3. Nos moldes em que foi consagrado como um Direito Fundamental, o direito de propriedade tem uma finalidade específica, no sentido de que não representa um fim em si mesmo, mas sim um meio destinado a proteger o indivíduo e sua família contra as necessidades materiais.

Enquanto adstrita a essa finalidade, a propriedade consiste em um direito individual e, iniludivelmente, cumpre a sua função individual. 4. Em situação diferente, porém, encontra-se a propriedade de bens que, pela sua importância no campo da ordem econômica, não fica adstrita à finalidade de prover o sustento do indivíduo e o de sua família. Tal propriedade é representada basicamente pelos bens de produção, bem como, por aquilo que exceda o suficiente para o cumprimento da função individual.

5. Sobre essa propriedade recai o influxo de outros interesses - que não os meramente individuais do proprietário - que a condicionam ao cumprimento de uma função social.

6. O cumprimento da função social exige do proprietário uma postura ativa. A função social torna a propriedade em um poder-dever. Para estar em conformidade com o Direito, em estado de licitude, o proprietário tem a obrigação de explorar a sua propriedade. É o que se observa, por exemplo, no art. 185, II, da CF.

7. Todavia, a função social da propriedade não se resume à exploração econômica do bem. A conduta ativa do proprietário deve operar-se de maneira racional, sustentável, em respeito aos ditames da justiça social, e como instrumento para a realização do fim de assegurar a todos uma existência digna.

8. Há, conforme se observa, uma nítida distinção entre a propriedade que realiza uma função individual e aquela condicionada pela função social. Enquanto a primeira exige que o proprietário não a utilize em prejuízo de outrem (sob pena de sofrer restrições decorrentes do poder de polícia), a segunda, de modo inverso, impõe a exploração do bem em benefício de terceiros.

9. Assim, nos termos dos arts. 186 da CF, e $9^{\circ}$ da Lei n. 8.629/1993, a função social só estará sendo cumprida quando o proprietário promover a exploração racional e adequada de sua terra e, simultaneamente, respeitar a legislação trabalhista e ambiental, além de favorecer o bemestar dos trabalhadores.

10. No caso concreto, a situação fática fixada pela instância ordinária é a de que não houve comprovação do descumprimento da função social da propriedade. Com efeito, não há como aferir se a propriedade apesar de produtiva do ponto de vista econômico, este aliás, o único 
fato incontroverso - deixou de atender à função social por desrespeito aos requisitos constantes no art. $9^{\circ}$ da Lei n. 8.629/93.

11. Analisar a existência desses fatos, conforme narrado pelo agravante, implica revolvimento de matéria probatória, o que é vedado a esta Corte Superior em razão do óbice imposto pela Súmula 7/STJ.

Agravo regimental improvido. ${ }^{143}$

Como se vê nestas citações, na análise de casos concretos a referência à função social depreende-se por um exercício exegético teleológico segundo não só aos fins da norma civil, mas antes, perpassando pelos fins da norma constitucional, indo muito além de seu texto ordinário, para subir a uma dimensão absolutamente prospectiva e substancial, coadunando o resultado da análise aos interesses sociais congruentemente estabilizados e relevantes, ligados em plano individual ao desenvolvimento da subjetividade humana e em plano coletivo ao desenvolvimento de uma consciência coletiva do que seria o uso da propriedade em face de sua função voltada para o cumprimento de um dever social.

E faz todo sentido no uso da tópica entender-se que se os sistemas estão em constante operação de fechamento e abertura, posto que, as soluções desenvolvidas por um conjunto de argumentações concretizadoras do pensamento civil-constitucional, não se fixarão como estanques e nem mesmo como panaceias em todos os casos e em todos os momentos. A tópica aqui aliada ao desenvolvimento da jurisprudência propiciará no campo dos problemas a serem resolvidos, um caminhar constante sempre no compasso do desenvolvimento da comunicação sistêmica em plano superior.

Passaremos agora a um desdobramento da análise da função social, atribuindo-a ao exame dos contratos. Sob o mesmo enfoque, buscaremos demonstrar a influência do princípio na construção da teoria dos contratos.

${ }^{143}$ BRASIL. Superior Tribunal de Justiça. Recurso Especial no 1138517/MG. Rel. Ministro Humberto Martins, segunda turma, julgado em 18/08/2011, DJe 01/09/2011. 


\subsection{Por um Direito Civil-Constitucional: A função social dos contratos e uma breve análise da teoria contratual}

A função social dos contratos, delimitada no atual Código Civil em seu artigo $421^{144}$ assim preconiza: “A liberdade de contratar será exercida em razão e nos limites da função social do contrato." E este viés tido como a expressão moderna de um preceito de ordem pública inserido no contexto civilista como uma resposta a uma interlocução com o princípio maior da função social, não adveio senão de uma formação que a princípio não encontrou amparo nas codificações oitocentistas que relegou aos contratos uma função meramente de fomentador das atividades econômicas no seio comercial.

Orlando Gomes ${ }^{145}$ como pioneiro nas pesquisas do alcance do metaprincípio da função social no seio civil, aduziu que a função econômico-social dos contratos passou a ser a razão determinante da criação de toda uma malha jurídica protetiva. A incidência de normas controladoras e dirigentes se dá em face dessa função, na visão do grande mestre.

E ao albergarmos essa racionalidade no período atual, essa função dúplice da avença contratual ganha dimensões ligadas não somente à sua realização econômica como a sua utilidade para os fins sociais a que se destina, o que certamente o guinda a uma cláusula geral afeta à realização de primados constitucionais que estão ligados, por sua vez, à estrutura humanitária estampada no seio constitucional.

Para tanto, na esteira de Fachin ${ }^{146}$ a função social hodiernamente apresenta duas dimensões: uma intrínseca ligada ao equilíbrio das partes na relação contratual, o que de fato tangencia por valores ligados à preservação da dignidade humana, sem olvidar

\footnotetext{
${ }^{144}$ Cf. Lei 10406/02

${ }^{145}$ GOMES, Orlando. Contratos. Rio de Janeiro: Forense, 2000, p. 20 e ss

${ }^{146}$ FACHIN, Direito Civil sentidos, transformações e fins. op.cit. p.125
} 
à eticidade contida no princípio da boa-fé objetiva que aqui se interliga para a consecução desta dimensão; uma extrínseca que pertine aos efeitos do contrato no campo das relações sociais.

Sob este prisma a função social encerrada no Código Civil alcança status de norma pública apontando o entendimento no sentido de que o contrato realiza tal função entre as partes contratantes numa acepção da dimensão solidária exigida pelo ordenamento constitucional, mas também atinge aqueles que não fizeram parte da relação. Isso significa dar um sentido teleológico ao contrato que se submete a critérios de validade formal (sujeito, objeto, forma), mas também, se submete a critérios de ordem pública, que uma vez desrespeitados carregam o contrato para uma possível invalidade total ou parcial.

Um contrato proscrito no ordenamento, não só é um contrato que não atende a um equilíbrio material entre os contratantes, como também, fere metaprincípio ligados de forma indissociável à avença. E a própria norma civil assevera em seu artigo 2035 o sentido de tal afirmação: “ Nenhuma convenção prevalecerá se contrariar preceitos de ordem pública, tais como os estabelecidos por este Código para assegurar a função social da propriedade e dos contratos. "

Por conseguinte, a autonomia privada das partes passa a ser dirigida e limitada por este metaprincípio que, a despeito das discussões sobre sua abstração e incidência é de toda sorte inafastável, agindo como pilar de sustentação da própria teoria dos contratos.

A esse respeito, enquanto princípio, esta função social realiza-se no contexto contratual à guisa de princípios constitucionais orientadores e ao mesmo tempo objetivos, porque aplicáveis no contexto das partes contratantes, como a dignidade da pessoa humana e seu respeito e a igualdade substancial, assim como a solidariedade. 
Desta feita, ainda que determinado contrato alcance validade formal, quanto à capacidade dos sujeitos, a licitude do objeto e a forma de consecução, se ainda assim não observar esta função desde o momento de sua concepção, até o momento de sua execução e pós-execução, então abrir-se-ão os portais da invalidação deste contrato.

Seja por eventos imprevisíveis que levem ao reequilíbrio da relação ou sua resolução por onerosidade extrema; seja pela presença de vícios de ordem privada ou pública quanto à vontade; seja pela ofensa à boa-fé, a verdade é que na análise da relação contratual, o aplicador do direito vai se ater à realização desta importante função, sem olvidar sua interlocução com o viés econômico e a utilidade deste contrato o seio social. Assim, a esfera funcional dos contratos submete o aspecto estrutural, entendido este com a relação subjetiva interna da relação contratual. E essa submissão ou condicionamento da face estrutural do contrato, estabelece a partir do princípio da dignidade da pessoa humana como mote, uma ponte de interligação com o sistema constitucional.

A prova desta transição encontra-se nos artigos citados que foram inseridos no contexto do codex para alinhar o pensamento jurídico contratual com a nova dimensão solidária de nossa época.

Isso não só significou uma relativização do pensamento em torno da pacta sunt servanda, mas também uma ordem de reconstrução da norma civil, a pretexto de garantir a todos os que celebram contratos, igualdade substancial e respeito á sua estrutura enquanto sujeito de direitos.

E se isso nos remete a imaginar o Código de Defesa do Consumidor como a expressão mais proeminente desta igualdade em campos de relações contratuais que por si só já nascem em desequilíbrio, mormente, em desfavor do vulnerável consumidor, a 
verdade é que este é um exemplo da contribuição normativa civil na reconstrução do pensamento privado.

Enquanto metaprincípio, a função social se espraia em qualquer seara do sistema jurídico em que haja um contrato sendo celebrado. A liberdade de contratar, aliase à liberdade de contratação submetida a uma ordem pública para direcionar os contratantes a uma manifestação condicionada de suas autonomias privadas a fim de que observem uma série de deveres normativos ligados à esfera constitucional, tendo como valor fundante a dignidade do ser, não só em esfera individualista do contrato, mas em todo contexto social.

Desapegando-se um pouco da exemplificação em torno das relações consumeristas, se observarmos um contrato de trabalho, veremos de antemão que existe uma ligação direta da avença a uma série de normas de caráter social, tutelando as liberdades individuais dos trabalhadores e mais do que isso, limitando o poder dos empregadores em qualquer tentativa de impor desequilíbrio à relação, com a aposição de cláusulas que firam frontalmente, direitos e garantias individuais dos trabalhadores.

Um contrato de trabalho que feito por pessoas capazes e na forma adequada pela lei, ainda assim será inválido no todo ou em parte se alguma ou algumas de suas cláusulas dispuserem termos que de algum modo nulifiquem direitos trabalhistas estabelecidos a partir de garantias fundamentais constitucionais.

Por isso é interessante reafirmar que a teor não só da realização de uma justiça social para redução de desigualdades sociais e regionais (artigo 170 da Constituição Federal e consectários) o contrato realiza uma função social se há pelas partes a perseguição de valores maiores, como a dignidade, que serão o ponto de toque da relação contratual no sistema civil, com o sistema constitucional. 
Então não é despiciendo falar aqui que na realização de sua função econômica, o contrato também visa a realização de justiça ao se interligar a preceitos de ordem pública estampados no ordenamento constitucional como o artigo 170 aqui citado, pois, a execução condicionada da avença é sempre voltada ao equilíbrio econômico das partes.

Por isso, se em sua execução um dos contratantes é atacado por evento externo à relação, ou mesmo por ato improbo da outra parte, o que decorre da onerosidade excessiva é sempre um decréscimo da própria existência humana. E não falamos aqui somente de uma redução patrimonial, locupletamento ilícito ou sem causa. Falamos das consequências mediatas desta aniquilação do equilíbrio.

Daí porque, unindo-se a princípios fundamentais da Constituição, como os elencados no artigo 170, direitos e garantias fundamentais e o valor supremo da dignidade da pessoa humana, virão outros princípios antiquíssimos do Direito Civil haurirem nova significação de seus conceitos para interliga-los à ótica prospectiva constitucional.

Podemos citar aqui o princípio venire contra factum próprio, a cláusula rebus sic stantibus, a exceptio non adimpleti contractus, dentre outros.

E como já se vem defendendo neste trabalho, não se trata aqui de mero exercício hermenêutico, mas de uma transição pela qual vem passando o Direito Civil, inserido neste caminho dinâmico de transformação de valores superiores num contexto de hipercomplexidade social e policontexturalidade que impõem aos sistemas internos tanto Civil, quanto constitucional, uma adequação de velocidade transformativa que ultrapassa a mera subsunção e a exegese pura, para colmatar novas normas que vão se inserido no sistema civil, modificando-o e reestruturando-o. 
E são nas palavras de Günther Teubner ${ }^{147}$ que vamos mais uma vez buscar amparo para essa argumentação, quando este importante pensador vai considerar o sistema contratual (assim chamado por ele) em três níveis de formação sendo: 1- um nível de relações interpessoais entre as partes contratantes, onde a interlocução se dará pela autonomia volitiva voltada para o fim comum da relação (nível de interação); 2- um nível de concepção mercadológica, onde o contrato realiza sua função econômica em conexão com o mercado (nível institucional); 3- um nível de tratamento do contrato segundo as exigências valorativas da sociedade, colocando a autonomia privada sob o pálio dos preceitos consagrados socialmente. Neste nível não há primazia da individualidade dos agentes contratantes, cedendo este espaço para uma ordem social dirigente e determinante do contrato (nível social).

E nesta perspectiva os contratos não existem isoladamente e nem tem a sua eficácia aferida no plano individual das vontades contraentes, mas antes projetam-se no interior do sistema jurídico, submetendo sua validade à controladoria do ordenamento que por sua vez, busca estabilizar suas normas naquilo que o sistema social vai considerar como um comportamento que se adeque ás expectativas congruentes em seu interior.

Teubner, deixa claro que os níveis propostos em sua teoria não se sobrepõem hierarquicamente, mas são dotados de distinção e, pensamos, de interação, fazendo parte do desenvolvimento do sistema, com evolução independente, mas que no ambiente do contrato, encontram uma medianiz comum, ou seja, um ponto de restabilização de variações que por sua vez não são a evolução em si, já que, tais expecativas serão congruentes ao sistema se encontrem resistência e aderência, o que por si só repele comportamentos desviantes, que não encontrem amparo no conjunto normativo fundante,

147 TEUBNER, Günther. O direito como sistema autopoiético. Lisboa/PT: Fundação Calouste Gulbenkian, 1994, p. 237e ss 
e aqui chamamos a atenção mais uma vez, para a dignidade da pessoa, que enraizados no ordenamento não admitem o retrocesso.

Naquilo que chamou de nível de interação, ${ }^{148}$ este pensador concebe as normas contratuais como fruto não apenas da autonomia de vontade das partes, mas como um resultado de expectativas que não são simplesmente resultantes de uma exegese do ordenamento, mas antes de um conjunto de preceitos diretivos que também se encontram no ordenamento, mas residem conjuntamente no contexto da própria sociedade.

Em sua esfera institucional ${ }^{149}$ os contratos estão em constante relação com o sistema econômico que possui característica abarcante em face dos demais sistemas. Aqui o que se depreende do raciocínio sistêmico de Teubner é que os contratos se desenvolvem em constante busca de adaptação e equilíbrio normativo com este sistema. Então, no processo comunicacional com o plano econômico, o Direito ora vai determinar um conjunto de normas dirigentes que busquem atrelar o contrato ao sistema econômico mantendo o equilíbrio não só do vínculo entre as partes, sempre passível de revisão em nosso meio jurídico brasileiro (rebus sic stantibus), mas também para limitação de direitos que decorrem de cláusulas gerais empregadas no contrato, com fulcro não somente em critérios econômicos, como também, em valores fundamentais.

Por último, em nível social ${ }^{150} \mathrm{o}$ contrato se volta ás exigências do sistema social, que sempre em evolução, vai se determinar pelo resultado sempre improvável do resultado da estabilização, após a variação e seleção. Assim, o contrato estará patente de cláusulas gerais que seriam hipóteses normativas que se colocam em generalidade, mas que atuam para direcionar o tratamento jurídico dado a casos concretos. Não se trata de um exercício de adequação normativa, muito menos de subsunção. Trata-se aqui de

\footnotetext{
148 TEUBNER, op.cit. p. 239

149 Idem, ibidem.

150 Idem, ibidem.
} 
entender que o sistema social, cada vez mais diferenciado funcionalmente e hipercomplexo, o grau de generalidade de cláusulas gerais está em permanente mutação.

Em nível social este entendimento do jurista alemão reflete o pensamento de uma função social no contrato, a partir do momento que concebemos a celebração das avenças como normas submetidas a cláusulas gerais que exercem um dirigismo no contrato não somente a nível normativo-jurídico, mas para além, em nível social. A boafé objetiva que trataremos como um último exemplo deste modelo de reconstrução do Direito Civil é um claro destaque dessas cláusulas e define muitíssimo bem esse desenvolvimento contínuo da teoria contratual.

Sob a batuta de tais cláusulas, a aplicação em casos concretos, direcionando a discussão para a aplicação prática deste caráter funcional do contrato, revela que o contrato segue o resultado da evolução do sistema social, onde o Direito representa um símbolo de limitação formal, mas abre espaço ao julgador e operador do Direito para aplicar em cada caso a solução mais adequada com o contexto social e seus anseios e valores vigentes, claro, após a análise da existência, validade e eficácia perante a norma civil.

Mas, seja como for, isso influencia diretamente a reconstrução da norma civil, porque o sistema jurídico, mormente o constitucional, a par de internalizar valores e princípios que hoje compõem a dimensão solidária da sociedade moderna, reflete em comunicação interna estes preceitos e é claro isso atinge a estrutura normativa do Direito Civil. Veja-se a exemplo, a consagração da boa-fé objetiva em nosso Código em seu artigo $422^{151}$ que aliada à exegese do já citado artigo 421 do mesmo diploma, anuncia esta transição do sistema Civil em prol da realização de paradigmas constitucionais.

${ }^{151}$ Cf. BRASIL. Lei 10406/02. Os contratantes são obrigados a guardar, assim na conclusão do contrato, como em sua execução, os princípios da probidade e boa-fé. 
E estamos convencidos que estas pontes de transição encontram seus pináculos em princípios fundamentais, dos quais, sempre vamos destacar a dignidade da pessoa humana como principal, mas não único, valor determinante desta transposição sistêmica interna, considerando ser o homem, enquanto pessoa, ou como um constructo de sujeito de direitos, individual ou em sociedade, o alvo final de toda construção da ciência jurídica.

E como última parte desta análise no capítulo passaremos a tratar da boa-fé objetiva num contexto de eticidade e sua contribuição na reconstrução deste assim chamado Direito Civil-Constitucional.

\subsection{Por um Direito Civil-Constitucional: A boa-fé objetiva em sua dimensão de eticidade pautada com o princípio da dignidade da pessoa humana.}

Desde os idos de Roma, os contratos são protegidos em face do princípio actiones bonae fidei ${ }^{152}$ e se torna interessante este levantamento histórico inicial, porque no haurir de pesquisas sobre o pensamento romano a pessoa, enquanto sujeito, era considerada o centro da relação jurídica, guardadas as devidas proporções em face de sua condição e posição social. Mas, seja como for o magistrado romano ao julgar questões contratuais, deveria apreciar subjetivamente as circunstâncias que permearam a negociação, volvendo sua análise principalmente para a prática de vícios redibitórios e elevar seu julgamento à busca de um juízo calcado em preceitos éticos adotados já em Roma, quanto à exigibilidade de se observar a pacta sunt servanda, no entanto, em torno da exigibilidade de um equilíbrio justo e leal entre as partes.

${ }^{152}$ SANTOS JUSTO, Antonio. Direito Privado Romano (Direito das Obrigações) II. 4.ed. Coimbra/PT: Coimbra Editora, Boletim da Faculdade de Direito da Universidade de Coimbra, 2014, p. 27 
Em mesma dicção Santos Justo ${ }^{153}$ assevera como exemplo desses contratos baseados na boa-fé, dentre outros, as locatio-conductio, as quais nos apegamos para delinear um breve resgate da racionalidade romana, quanto a centralidade do sujeito na relação, enquanto homem livre.

Sendo um contrato consensual, desde Roma, as locatio, derivadas nas locatioconductio rei, locatio-conductio operarum e locatio-conductio-operis, se davam mediante a locação de coisas ou a prestação de determinados serviços ou realização de boras respectivamente, todos mediante o pagamento de remuneração (mercês sempre baseadas no pretium que deveria consistir em pecunia).

Nas locatio-conductio operarum, importante frisar que a obrigação de fazer restringia-se à atividade laboral à disposição do locator o que foi uma evolução já que essa espécie contratual fora antes originariamente uma parte das locatio-conductio rei, numa sociedade em que o trabalho humano era fornecido por escravos filiifamilias e patresfamilia, cuja titularidade do domínio sobre o sujeito fazia de sua atividade um proveito cessível a terceiros ou a favor de seu senhor. Então, o trabalhador nesse período não era muito diferente de um escravo, salvo por sua condição de homem livre. O trabalho desprendido por estes homens era considerado vil e ignóbil, principalmente por que realizavam trabalhos manuais.

Mas, graças ao avanço jurisprudencial romano em torno do conceito de boafé, baseado num ideal de justiça e lealdade que o homem livre sui iuris foi guindado ao patamar de um operae, podendo locar sua atividade de modo atrelado ao exercício livre de manifestação volitiva, o que sem dúvida, importaria num exercício livre de sua personalidade jurídica reconhecida enquanto homem livre.

153 Op.cit, p. 28 e ss 
Essa centralização da figura do homem no centro da relação jurídica alinhouse com o preceito de boa-fé elencado em Roma de sorte que influenciou o pensamento jurídico nos tempos que se seguiram, para se tornar importante ratio na construção de um Direito das relações laborais.

Em salto histórico, Schreiber ${ }^{154}$ denuncia uma profunda modificação nas relações contratuais de trabalho com o cenário de uma revolução no modo industrial e a massificação acentuada das relações contratuais. Em sua base de raciocínio este autor demonstra como a neutralidade das relações obrigacionais descortinou uma incrível necessidade de acréscimo nestas relações de princípios relacionados a um fundamento humano de justiça e equilíbrio na relação.

Após essas considerações, podemos afirmar de início que a boa-fé desde o início do pensamento romano vem instituindo-se em alicerces de eticidade que serão introduzidos ao universo jurídico com mais ênfase, em face da tutela do jus gentium em face do incremento comercial, que paulatinamente vai elevando a noção de contrato em face de sua relação com o sistema econômico.

Num salto histórico, a noção de boa-fé enquanto princípio teve na Alemanha sua maior acepção ligada à noção de lealdade e justiça (treu und Glauben) que na visão de Judith Martins-Costa ${ }^{155}$ significou um avanço no pensamento germânico inserindo no lugar da fidelidade romana a concepção de uma lealdade e crença em valores superiores que se referiam as qualidades humanas agora objetivadas.

\footnotetext{
${ }^{154}$ SCHREIBER, Anderson. A boa-fé objetiva e o adimplemento substancial. In: Direito Contratual: temais atuais. Coord: Giselda Maria Fernandes Novaes Hironaka e Flávio Tartuce. São Paulo: Método, 2007, p. 125-146. E é interessante que fazendo referência a Paul Lafargue, o autor revela a forma emblemática com que os contratos estabelecidos no século XIX eram conduzidos: "Que miserável aborto dos princípios revolucionários da burguesia! - foi a enfática afirmação de Paul Lafargue, ao constatar que 'os forçados das prisões trabalhavam apenas dez horas; os escravos das Antilhas, nove horas em média, enquanto na França - que havia feito a revolução de 89, que havia proclamado os pomposos Direitos do Homem - havia manufaturas onde a jornada de trabalho era de dezesseis horas'. " LAFARGUE, Paul. O direito à preguiça. São Paulo: Hucitec/Unesp, 1999, p. 77, apud SCREIBER, Anderson. Idem, ibidem.

${ }^{155}$ MARTINS-COSTA, Judith. A boa-fé no Direito Brasileiro. São Paulo: RT, 2000, pg. 123 e ss.
} 
O Código Civil Alemão traz consigo esta temática em seu artigo, quando dispõe o uso da boa-fé em prol do interesse comum, o que sobreleva ao entendimento de uma boa-fé calcada em um princípio de eticidade, conforme se vê:

Der Schuldner ist verpflichtet, die Leistung so zu bewirken, wie Treu und Glauben mit Rücksicht auf die Verkehrssitte es erfordern. ${ }^{156}$

Por conseguinte, podemos entender o princípio da boa-fé antes de tudo, como uma diretriz principiológica calcada em preceitos éticos guindados ao sistema jurídico, de forma que alcancem eficácia e vinculação da validade da própria relação jurídica, o que significa em última instância o poder abarcante de cogência a esses preceitos.

E torna-se especialmente importante ressaltar para os moldes deste trabalho, que a boa-fé em seu aspecto objetivo, funda-se em deveres que são norteados por parâmetros éticos que se convertem em deveres jurídicos chamados de anexos ou de proteção como a lealdade, confiança, assistência, informação, confidencialidade ou sigilo e outros tantos que no bojo de sua concepção vão se voltar para a preservação dos sujeitos que estão participando da relação.

Mas, é importante ressaltar que mesmo sendo deveres objetivamente considerados, os mesmos emergem da ponderação de valores ou expectativas que estão

\footnotetext{
${ }^{156}$ ALEMANHA. Bürgerliches Gesetzbuch. Disponível em: https://www.gesetze-iminternet.de/bundesrecht/bgb/gesamt.pdf. Acesso em 20/10/2015. O Devedor é obrigado a efetuar a prestação de boa-fé e em consideração com o uso comum (tradução livre nossa). E apenas a título de ilustração, trazemos também, a dicção do artigo 1134 do Código Civil Francês, que em mesma ideologia assim assevera: "Les convetions légalement formées tiennet lieu de loi à ceux qui les ont faites. Elles ne peuvent être révoquées que de leur consentement mutuel, ou pour les causes que la loi autorise. Elles doivent être exécutées de bonne foi. " As convenções legalmente formadas tornam-se lei entre as partes que a fizeram. Elas só podem ser revogadas apenas por seu mútuo consentimento ou pelas causas autorizadas por lei. Elas devem ser realizadas de boa-fé. (Tradução nossa). FRANÇA, Code Civil. Op.cit.
} 
enraizadas no âmago do sistema social. Assim, possuem caráter evolutivo tal qual a própria sociedade.

Stolze e Pamplona ${ }^{157}$ vão observar, que existem as seguintes funções a serem desempenhadas pela boa-fé objetiva: a) uma função interpretativa; b) uma função criadora de deveres jurídicos anexos ou de proteção; c) função delimitadora do exercício de direitos subjetivos.

A primeira função está ligada ao referencial hermenêutico disposto ao exegeta que interpreta a relação contratual, de modo a extrair da norma analisada, isto é, do contrato, o sentido social razoavelmente mais adequado aos fins a que se destina aquele contrato. Significa atender aos fins comuns, ou à função social que aquele contrato precisa exercer.

Sob este pensamento, conforme preleciona Couto e Silva ${ }^{158}$ o princípio da boa-fé serve como instrumento de colmatação, como integrador da interpretação na busca dos propósitos perpetrados pelas partes em contrariedade com os usos comuns e os valores consagrados pela sociedade como eticamente corretos para determinada situação.

Nesse processo hermenêutico cuida de conferir justa medida à vontade que se interpreta - pois que o contrato não se constitui de duas volições, ou de uma oferta e uma aceitação, isoladamente, mas da fusão desses dois elementos - e de evitar-se o subjetivismo e o psicologismo a que se chegaria sem dificuldade, caso o interesse de ambas as partes não fosse devidamente considerado $^{159}$.

Noutro turno, em sua função criadora a boa-fé atuará em razão de deveres invisíveis à relação, ou seja, não expressos no termo contratual, mas que prevalecerão

${ }^{157}$ GAGLIANO, Pablo Stolze; FILHO, Rodrigo Pamplona. Novo Curso de Direito Civil. Volume IV. Contratos: tomo 1; Teoria Geral. 3.ed. rev., atual. e ampl. São Paulo: SARAIVA, 2007, p. 69 e ss. ${ }^{158}$ SILVA, Clovis do Couto e. A obrigação como processo. Op.Cit., p. 35 e ss

159 Idem, ibidem. 
como deveres anexos de proteção das partes, com força normativa o suficiente para condicionar a validade e eficácia da relação. Aqui deveres como a lealdade, a confiança recíproca, a assistência, a informação, o sigilo e outros que podem surgir na relação concreta, se ligam à crença de realização do negócio jurídico com amparo na probidade, no respeito e diligência das partes uma para com a outra, sendo que a quebra, ocasiona o inadimplemento do vínculo independentemente de culpa.

E finalmente em sua função delimitadora do exercício de direitos subjetivos, a boa-fé objetiva buscará evitar o exercício abusivo de direitos subjetivos e justamente neste viés, existe forte ligação com o metaprincípio fundante da dignidade da pessoa humana.

A iniquidade da relação jurídica acontece quando as partes agem em desconformidade com o ideal básico da lealdade e probidade que deve ser exercitado reciprocamente na relação jurídica.

A quebra de tais deveres desvaloriza a pessoa humana, estabelece a tirania do outro que imantado por um direito subjetivo usado de forma abusiva, sobrepuja e aniquila a essência do sujeito de direitos, privando-o do exercício livre não só de sua autonomia privada, como também, quebra sua confiança no outro desencadeando a invalidação da relação em qualquer de seus momentos, seja na fase de pontuações, até o momento póscontratual.

Não é por acaso que é nas relações de consumo, mormente no Código de Defesa do Consumidor, que o princípio ganhará exponencial proeminência em vários trechos deste microssistema, onde a proteção à pessoa inserida em relação economicamente pautada, com outro sujeito que não raras vezes é detentor de grande poder econômico e impõe as cláusulas em face de contratos predeterminados e de adesão, 
pode desde o momento da oferta, expor o vulnerável à situações que diminuam sua condição de pessoa frente à disparidade do vínculo que está prestes a formar.

Por isso mesmo a criação de vínculos baseados na quebra da boa-fé objetiva, são repulsivos em qualquer momento da relação de consumo e mais ainda quando a quebra advém de uma ferida oriunda da participação do fornecedor, porque este, enquanto detentor de todos os meios de produção e econômicos, deve ser muito mais comprometido com a manutenção da lealdade e probidade na relação, sob pena de ferir a parte consumidora em aspecto moral e não apenas material.

Por estar ligada a eticidade, tem-se o liame da boa-fé objetiva com a dignidade da pessoa humana porque antes de ser princípio fundante de toda uma gama de garantias fundamentais é um valor consagrado no sistema social a partir de uma construção histórica que não é um privilégio de uma coletividade, mas liga-se espiritualmente à própria humanidade.

Dessa forma, ainda que a relação jurídica alcance uma validade formal quanto a elementos ligados à capacidade, licitude e forma, o fato é que a quebra da boa-fé invalida no todo ou em parte a avença, em face da profundidade do inadimplemento gerado. Não se trata aqui de uma ofensa culpável de uma parte à outra. Avulta-se neste caso a importância dos deveres anexos e protetivos a que estão submetidos os participantes da relação contratual o que afasta uma visão neutra e meramente estrutural ${ }^{160}$ da relação obrigacional para dar lugar a interesses subjacentes que estão em substrato social.

Trata-se de ferida aberta no contexto social. A sociedade não pode tolerar que a iniquidade de vínculos contratuais macule a dignidade dos participantes, muito mais se praticada por um dos sujeitos da relação. A tolerância à quebra da boa-fé desencadearia um desequilíbrio valorativo e normativo no seio social, propiciando a colonização do 
sistema social em face de comportamentos desviantes que não se coadunariam com as expectativas congruentes já assentadas em face de um contexto evolutivo que já se encontra resistente e estabilizado no consciente coletivo.

Por fim neste trabalho, numa derradeira análise que perpassa a aplicação da tópica aqui também se ressalta, na função hermenêutica realizada pela boa-fé enquanto integradora do sistema jurídico em face de preceitos éticos absorvidos e objetivados, a atuação tanto em nível jurisdicional e jurisprudencial, quanto a nível operativo do Direito de uma análise de adequação e teleologia destes preceitos aplicados aos casos concretos, de modo que, se busque aqueles que vão cercanear com mais eficiência determinada relação jurídica, impondo às partes na relação tomada de condutas que à guisa do comprometimento com a lealdade, equidade e probidade, sejam conducentes da relação a um termo de equilíbrio, justiça e igualdade substancial.

Trata-se aqui do a doutrina alemã convencionou chamar de violação positiva do contrato que vem sendo aplicada não só pela doutrina brasileira ${ }^{161}$ como por nossos Tribunais que em hipóteses concretas verifica que embora adimplida a prestação contratada, se houver descumprimento culposo de dever imposto pela boa-fé objetiva em face da causa contratual, pode haver revisão ou resolução da avença.

Afasta-se por consequência a concepção tradicional de que a consecução obrigacional se depreende do adimplemento puro e simples do vínculo em face da mora, para salientar uma diferenciação funcional do sistema em face da boa-fé que incide como vetor na relação determinando o atendimento à função concreta e causal do contrato atribuída ás partes desde o momento das negociações preliminares e mesmo após o momento de execução, conforme já salientado.

${ }^{161}$ SCREIBER, op.cit. p.137 


\section{CONCLUSÃO}

Este trabalho teve como objetivo demonstrar o fenômeno de transição do Direito Civil para um Direito Civil-Constitucional, sem querer de forma alguma criar uma tese, ou mesmo estabelecer um ponto de vista que venha exaurir a discussão. Trata-se de um pensamento inicial.

Ao contrário de querer exaurir, buscou-se apenas salientar um aspecto da discussão a partir de uma visão sistêmica e tópica, respectivamente, do fenômeno, num arquétipo racional calcado na abstração do modelo de teoria sistêmica em plano superior tanto pelas transversalidades entre ordens constitucionais, às quais não foi dada tanta ênfase, e depois para o processo de comunicação entre sistemas internos do Direito Constitucional pátrio e Direito Civil, cadenciando o raciocínio para o reflexo do resultado dessa comunicação já na esfera social e sua aplicação no contexto problemático e concreto.

No entanto, neste constructo do pensamento imaginamos que essa transição se daria por pontes erigidas sobre preceitos fundantes advindos de pensamento internalizado nas bases de nosso constitucionalismo e elegemos uma das principais que toca mais de perto o Direito Civil, qual seja, a dignidade da pessoa humana.

Desse ponto de partida foram várias as conclusões levantadas. Passemos a elas.

1- De início a caminhada se iniciou na tentativa de demonstrar este arquétipo, e passou pela demonstração de uma racionalidade, um caminho a partir de um modelo de análise, que servisse de sustentáculo aos argumentos propostos. Sem querer levar a discussão para o campo histórico de reconstrução do Direito Civil, o desafio tratar o problema a partir dos processos de evolução do Direito, principalmente o Civil e 
Constitucional, em meio a uma sociedade diferenciada e muito complexa. Admitimos, então, o pluralismo jurídico e esta complexidade como um traço marcante do presente século e partimos a análise desse contexto, já deixando para outro momento as análises quanto as codificações oitocentistas.

2- Nesta construção de uma racionalidade primeiramente buscamos resposta sobre a possibilidade de convivência entre tópica e uma teoria de sistemas. A resposta a esta questão seria crucial até para a continuidade do trabalho, porque pela formação imaginada desta ponte de transição, o âmago de toda discussão, realmente terminaria na aplicação no caso concreto e na evolução da jurisprudência (as aporias fundamentais de que trata Viehweg). Concluímos neste ponto, que apesar do sentido polissêmico do termo sistemas e suas várias teorias, e de uma suposta incompatibilidade entre tópica e sistemas, no ponto exato de uma concepção axiomática, e não numa realidade pronta e acabada, ou seja, lógico-formal, abrir-se-ia um portal para uma racionalidade baseada tanto numa teoria de sistemas, quanto na tópica como ferramenta de aplicação.

3- Já admitindo um modelo tópico-sistemático, passamos então a uma concepção de sistemas baseado em Luhmann, justamente para fazer a adequação com a tópica. Houve um questionamento inicial se o modelo habermasiano não se enquadraria melhor, porém, ao observarmos em Luhmann um modelo calcado num afastamento inicial do elemento subjetivo do cenário comunicacional, vimos que talvez fosse mais adequado para este arquétipo partir do pensamento Luhmaniano. Há uma explicação para esta escolha, que reside na acepção de que os processos de comunicação se dão em ambiente de diferenciação e em policontexto, num momento em que o sistema social caminha em passos largos. Então, os processos desviantes ocorridos e as expectativas congruentes tanto da comunicação do sistema Constitucional em via transversa com 
outras ordens de mesma natureza, quanto deste sistema com o sistema Civil em plano interno, se darão em momentos que podem ser separados em níveis que ao mesmo tempo mantém plena comunicação com os sistemas sociais em iguais estamentos.

4- Sob o viés deste cadenciamento de eventos que emergem dos processos de comunicação (dos quais nos afastamos dos processos com o sistema econômico para não alongar o objeto), concluímos que tal raciocínio se torna crucial para determinar como valores muitos dos quais transformados em princípios fundantes foram internalizados em nosso consciente coletivo. Vimos, dos estudos desprendidos para além de explicar a teoria de Luhmann, pudemos observar que o processo de evolução do sistema Constitucional, parte de uma evolução da ordem jurídica transversa constitucional, de onde as trocas de experiências, acúmulos de saber e restabilizações em face do contexto social hipercomplexo, acabam por evoluir o sistema constitucional interno, que por sua vez, ao criar mecanismos de resistência (força normativa constitucional) começa a irradiar tais preceitos (irritações de ambientes) para outros sistemas internos do sistema jurídico, e o sistema Civil começa a sofrer estas influências, não apenas por um critério de hierarquia normativa, mas por um processo de absorção daquelas expectativas congruentes ao sistema constitucional e ao sistema social como um todo, de modo que, ao que vimos, um processo de reconstrução do Direito Civil se torna evidente.

5- num outro ponto, para começar a determinar essa reconstrução, passamos a tratar da posição específica do Direito Civil neste cenário, porque se tornou importante primeiramente ultrapassar toda e qualquer discussão em torno da dicotomia público/privado, deixando para trás conceitos como o direito privado enquanto um egoísmo anterior à vida em sociedade e a norma pública apenas como representação estatal. Utilizamos como argumento determinante dessa discussão a teoria dos direitos 
fundamentais, como marco inicial para determinar a crise e os novos paradigmas do Estado Democrático de Direitos.

6-O objetivo de se usar a teoria dos direitos fundamentais foi justamente o de encaminhar o raciocínio construído ao longo do trabalho, para a dimensão atual dos preceitos constitucionais e como os tais estão influenciando o Direito Civil. Concluímos nesta parte que numa nova ordem de direitos numa dimensão de solidariedade o exercício de liberdades sem a interferência ilegítima do Estado irradiar-se-ia para o direito privado com fito de realização dos escopos constitucionais dentro de uma diferenciação funcional dos sistemas. Vimos também, que com a ruptura do paradigma liberal e potencialização da racionalidade em torno do indivíduo e sua emancipação, a dignidade da pessoa humana passou a ter importância muito maior em nosso tempo, o que, sem dúvidas, nos compeliu a erigi-la como pináculo desta ponte de transição a que vimos nos referindo.

7- Avançando o estudo passamos a construir um conceito de sujeito de direitos, porque no momento em que já se encontrava a temática duas questões precisavam ser resolvidas: o sujeito destinatário do resultado destes processos comunicacionais em nível abstrato e a sua dignidade como o valor/princípio fundamentador de toda a interligação entre Direito Civil e Constitucional. Usamos como ponto inicial desta construção a concepção hegeliana, voltada apenas para a demonstração da intersubjetividade a nível espiritual e da consciência, voltando o pensamento para as relações interpessoais em face do Direito Civil, onde são a tônica. Pudemos observar que a pessoa não poderia ser mera destinatária, mas como fim em si mesma, seria mais que destino, mas antes o fim da transformação da norma civil.

8- E aqui importante destacar, que tal concepção a pessoa torna-se o centro formador das relações interpessoais e, portanto, recebe todas as influências da constante evolução do sistema social, mas também do resultado comunicacional do sistema jurídico 
com outros sistemas, o que de fato nos leva a esclarecer, que apenas tecemos análise da constante comunicação entre ordens jurídicas e sistemas internos jurídicos com o sistema social, sem olvidar que conhecemos os constantes acoplamentos entre direito e política, ou do sistema econômico e suas constantes tentativas de colonização dos demais sistemas.

9- Se existem vários caminhos para a demonstração deste sujeito de direitos, inclusive, por uma teoria da personalidade jurídica, optamos por uma construção a partir da subjetividade valendo-nos de aspectos históricos e filosóficos com fito de enaltecer a essência da pessoa humana e sua contextualização no mundo do Direito, já que, o fim maior seria a concepção de sua dignidade. Com essa construção, tivemos como resultado o afastamento de uma institucionalização do sujeito de direitos, o que deveras é compartilhado por boa parte dos pensadores em Direito Civil. Isso se explica, por conta da teoria da personalidade civil que transforma o ente num constructo jurídico capaz de exercer os atos da vida civil.

10- Afastando a ideia da institucionalização e abstrativização da pessoa, pudemos coloca-la como essencial aos processos de restabilização de expectativas desviantes, porque, se num nível superior sua participação não existe enquanto ocorrem as comunicações e evoluções autopoiéticas dos sistemas, o fato é que ao mesmo tempo, a estabilização e resistência de todo comportamento variado, selecionado e restabilizado acaba sempre dependendo da aceitação humana, a nível social. Então, de qualquer forma, a opção por uma teoria habermasiana aqui nos afastaria da visão deste esquema, porque colocaria o destinatário na posição heterárquica de sujeito participante da comunicação pelo consenso, o que sem dúvida não é o que ocorre, porque os processos de estabilização partem do improvável e imprevisível. A resistência de expectativas é que dependerá do contexto social. Claro que o trabalho em si não se pautou pelas divergências teóricas entre 
Habermas e Luhmann, mas antes, buscou guindar conceitualmente o ser à esfera de um sujeito de direitos dotado de capacidades de exteriorização de sua personalidade.

11-A partir do momento em que se firmou o entendimento da centralidade da pessoa como resultante dos processos comunicacionais, tornou-se evidente também a necessidade de analisar a dignidade da pessoa humana como valor e princípio fundante principalmente de uma teoria dos direitos fundamentais que delineamos superficialmente por não ser o alvo deste trabalho. Mas de qualquer forma, pudemos observar que ao falarmos numa nova acepção de um Direito Civil-Constitucional, este princípio se evidenciou na temática como uma das principais colunas desta ponte de transição.

12- De um conceito inicial a temática em torno da dignidade da pessoa humana, já entendida por nós como um eixo fundamental nesta transposição do Direito Civil, foi delineada em seu contexto europeu, dada a importância daquele continente na formação de um pensamento valorativo e jurídico-constitucional em torno do primado da dignidade. Salientamos vários aspectos históricos, desde a Bill of Rights e o desenvolvimento do princípio no constitucionalismo alemão, muito mais com escopo de demonstrar como este valor foi sendo transformado em um princípio jurídico enraizado e impassível de retrocesso já há muito tempo.

13-Não houve como não destacar a importância dos direitos fundamentais como elementos irradiados do pensamento em torno da pessoa humana, momento em que, neste momento do trabalho, houve preocupação de demonstrar o fenômeno no contexto europeu que evoluiu ao patamar de tentativas de formação de um direito comum das gentes, com escopo final de assegurar as liberdades e a manutenção do princípio raiz que é a dignidade da pessoa humana. Neste ponto pudemos observar os porquês deste princípio ter se difundido em grande parte do mundo ocidental, mormente naqueles países solidificados em torno de um Estado Democrático de Direitos. Mas, o escopo deste 
trabalho refere-se a um Direito Civil-Constitucional no Brasil. Então, ficou clara a necessidade de ao menos delinear o processo no contexto latino americano e no Brasil, evidentemente.

14- A conclusão mais clara a que pudemos chegar, foi a de que os modelos iniciais de pensamento em torno do princípio da dignidade da pessoa humana e dos direitos fundamentais como seus concretizadores, foram durante o século XIX mera incorporação e influência de modelos eurocentristas. O resultado deste quadro foi que a formação do pensamento latino partiu de documentos constitucionais fincados num ideal de dignidade, isonomia e até certas liberdades, porém, sem a devida aplicabilidade e eficiência. O Direito Civil neste contexto, viveu em seara meramente privada dominado por um criticado processo de codificação baseado unicamente em regras, muitas delas de segundo grau, heranças de influências romanas, germânicas ou francesas, sem o devido mote na pessoa humana em sua acepção substancial dentro de um pensamento constitucional.

15- Neste mesmo contexto, pudemos observar nos tempos atuais, que houve significativa mudança neste contexto. E apenas para exemplificar, trouxemos ao trabalho brevíssima consideração da Constituição Equatoriana que convive com cenário de diversidade cultural e ética que a coloca no cenário perfeito de ilustração da grande diferenciação social e hipercomplexidade que o fenômeno traz consigo. No Brasil a efetivação plena da dignidade como um metaprincípio decorreu da Constituição de 1988 que por seu caráter analítico imprimiu um caráter plural no tocante aos direitos fundamentais, e concluímos que a objetivação de tais direitos no contexto interno promoveu a elevação do princípio da dignidade humana como esse eixo fundamental na interlocução entre os sistemas internos no ordenamento. 
16- Evoluindo um pouco mais a temática em torno da dignidade, sua valoração enquanto princípio e como horizonte normativo para a instituição dos direitos humanos, deu-lhes mais força para se colocarem como limites ao poder do Estado, porque como instrumentos da liberdade, tanto a dignidade quanto dos direitos fundamentais que nela se fundam devem ser vistos como princípios objetivos, o que sem sombra de dúvida, nos levou a concluir que são geradores de reflexos importantes nos conteúdos de direito privado, traduzindo-se em critérios significantes e validativos das relações jurídicas sejam em campos obrigacionais (contratos), seja em relações de direitos reais, com ampla proteção à propriedade e a boa-fé objetiva, em dimensão solidária e calcada em eticidade no contexto do sistema social diferenciado.

17- Partindo desse pressuposto entendemos ser necessário demonstrar a teoria dos direitos fundamentais como diferenciação social sob a ótica de Luhmann, fiéis ao pensamento esposado por este importante autor. Concluímos que, como bem definido na teoria, a complexidade social em face de processos de comunicação e acoplamentos estruturais entre sistemas heterárquicos em nível superior, tendem a provocar mais complexidade, e pressão seletiva e diferenciação também em relação aos subsistemas ou sistemas internos acoplados, como direito e política que vão contribuir na formação da Constituição. E esta constituição, dentro deste cenário funciona como uma limitadora de expectativas incompatíveis com o sistema jurídico, numa função chamada de “descarregante".

18- E neste ponto conseguimos chegar ao ponto da institucionalização dos direitos fundamentais que nada mais é, pudemos observar, que a concretude da dignidade da pessoa humana, considerando-a como valor supremo e metaprincípio gerador dos direitos fundamentais. Concluímos então que sob este prisma os direitos fundamentais 
em face dessa concretude são facilitadores da comunicação na diferenciação entre os sistemas Civil e Constitucional.

19- E por esta via depreendemos que a realização da dignidade da pessoa humana a partir de um Estado de bem-estar abarca um processo de inclusão de todos às prestações do sistema social. Então, na verdade o que existiria, a nosso sentir, seria uma sociedade do bem-estar, porque na institucionalização de toda uma gama de direitos fundamentais, limitando o poder do Estado e considerando a dignidade da pessoa humana como o valor máximo a ser respeitado, então, amparada pela Constituição teríamos uma sociedade com escopo de bem-estar e inclusão e o Estado como realizador de tal empreito. E de fato, pensando assim, a significância e valoração da dignidade da pessoa humana encontra sua força na realização política e jurídica de inclusão no sentido de integração, como quer Luhmann.

20- Este processo, pudemos observar, implica em vinculação dos sistemas internos em comunicação, e mais, implica em transformação destes. No caso do Direito Civil, tendo por paradigmas as normas constitucionais, existe forte tendência de sua reconstrução e não apenas uma releitura, tendo por objetivo a realização em concreto do princípio torrencial da dignidade da pessoa humana.

21- Consoante a realização desses direitos pelo sujeito, vimos que as liberdades como fatores de inclusão tornam-se insofismáveis quando entendidas enquanto valores assegurados em face de princípios objetivos fundamentais que têm como escopo final garantir e preservar a dignidade desse sujeito na realização de direitos subjetivos. Com base no exemplo do caso Lüth, muitíssimo citado em várias doutrinas, ficou claro que a proteção dos direitos fundamentais e da dignidade deste ser constituem-se em decisões valorativas que vinculam todo o ordenamento com fito sempre de evitar a 
intervenção ilegítima do Estado quando age em detrimento de tais direitos e atua em confronto com a dignidade do ser.

22-Das experiências com as violações da dignidade da pessoa humana o resultado que constatamos foi de evolução, pois induziu cada vez mais, em um processo contínuo a formação de mais direitos de caráter humano emanados do metaprincípio fundante em prol sempre da proteção das liberdades do ser, e consequentemente de sua dignidade, em primeiro lugar. O que se buscou demonstrar é que este movimento deu nova significância ao ser, evitando sua coisificação. E no aspecto relacionado a este trabalho, a autonomia privada nas relações contratuais transcendeu a esfera formal da livre contratação, para antepor a dignidade por via de uma tutela especial baseada numa reconfiguração da norma civil conduzindo-a à mesma dimensão prospectiva do sistema constitucional de onde retira as fontes necessárias para essa reconstrução.

23- No derradeiro capítulo pudemos então estruturar todo o pensamento para então, apresentar o arquétipo do que vínhamos tratando em todo o trabalho. Demonstramos como a transversalidade de ordens jurídicas ao longo de todo um período influenciou a formação do sistema constitucional, brasileiro principalmente, e como por via de processos sistêmicos irradiou-se para o sistema civil, agora em conformação com os valores constitucionais, o que denunciou um processo não apenas interpretativo da norma civil em face de uma hierarquia com a norma constitucional, mas em outro viés, a norma civil se mostrou em franco processo de reconstrução, muitas das vezes implicando em desconstrução de princípios muito antigos e privatistas para dar roupagem nova à norma civil. Um caráter substancial em face da Constituição.

24- Apesar dos exemplos concretos dessa transformação serem atuais, como a Lei 13.146/15, por opção, buscamos na dimensão de transformações mais antigas como a função social da propriedade, dos contratos e a boa-fé objetiva, os sinais dessa transição, 
e mais ainda, dessa reconstrução do Direito Civil. O resultado demonstrou que esse processo se projeta na estrutura do Direito Civil a partir de estruturações, que chamamos pontes de transição, que se erigem baseadas em sustentáculos garantidores da continuidade da existência do modelo social. Vimos que no atual contexto que a dignidade ocupa lugar de destaque na conceituação da função social e da boa-fé, às quais nos dedicamos analiticamente para demonstrar essas transições e novas estruturações da norma civil.

25- No tocante a tópica, pudemos observar que seu encaixe se dá em último estágio dessa transformação, já no enfrentamento dos problemas em concreto com guisa a construção de soluções não estanques e tão pouco impassíveis de reflexão e reavaliação, daí porque, vimos o quanto a tópica aprofunda relações com a jurisprudência. Em cada uma das análises dos exemplos dispostos no último capítulo, buscamos fazer essa interlocução, com intuito de demonstrar esse escalonamento e o encaixe final da tópica na aplicação concreta.

26- No tocante à função social, dedicamos a análise ao conceito primário de propriedade e sua representatividade no pensamento normativo-constitucional, para então evoluirmos em breve contextualização histórica e normativa sobre o conceito de função social, principalmente na Europa convulsionada no médio termo da história. Foi necessário esse resgate para fundamentar o enraizamento deste princípio que irradiou-se para o Brasil e foi acolhido transversalmente pelo ordenamento constitucional em algumas ocasiões de nossas constituições republicanas.

27-A conclusão vislumbrada no resgate do pensamento de alguns pensadores brasileiros, nos levou a crer que a partir da constituição de 1988, o conceito ganhou força e não se tratou apenas de um acolhimento de tendências mundiais. Vimos uma mudança estrutural do conceito onde a função social ganhou envergadura e dinamismo no seio 
constitucional guindando o princípio à objetividade e ao realismo, sem perder sua natureza jurídica de direito subjetivo. E o mais importante, para esta pesquisa, foi a possibilidade de se demonstrar no Código Civil como a objetividade de tal princípio mudou a estrutura valorativa e principiológica da usucapião, acrescendo no conceito e no conjunto de princípios, a função social como elemento inarredável. Na evolução da análise de cada modalidade usada como exemplo, ficou clara a importância dada não só à relativização da propriedade em face de sua função social, como também, a proteção da dignidade da pessoa humana como pano de fundo.

28- No plano concreto pudemos observar que a tópica pode se prestar ao desafio de buscar soluções para realização desta função direcionada a sua consecução diante do problema apresentado. Para demonstração deste resultado, colacionamos ao trabalho, partes de decisões importantes em períodos diferentes, mostrando a evolução do conceito na jurisprudência do Superior Tribunal de Justiça

29- Irradiando a discussão para função social dos contratos, pudemos observar que lógica ad liberdade de contratação sofreu profundas mudanças com a inserção da ideia de uma função contratual. Isto, porque a norma contratual mantém intenso contato com o sistema econômico, então, guinda-la ao plano social é, deveras, uma tarefa difícil, porque a razão determinante dos contratos não mais poderia ser apenas o cumprimento obrigacional e a satisfação econômica, como também, a obediência a preceitos solidários e até éticos visando a satisfação do sistema social. Assim, enquanto cláusula geral, a função social elevou os contratos à categoria de normas concretizadoras de fins sociais o que seguramente remete à realização de primados constitucionais, como é a dignidade da pessoa humana.

30- E uma das conclusões mais importantes levantadas na pesquisa foi a de que esse aspecto funcional submete o aspecto estrutural contratual. Houve profunda 
modificação também, nas estruturas normativas e vetustas do Direito Civil. Isso significou não apenas uma relativização de princípios, mas também uma garantia de igualdade substancial entre as partes contratantes. Tornou-se um critério de validade contratual a nível institucional segundo as exigências sociais e de preservação da pessoa, como nos enriquece o Código de Defesa do Consumidor numa série de normas ali insculpidas ou dos contratos de trabalho, vistos apenas sob este prisma.

31- $\mathrm{Na}$ análise da boa-fé objetiva ficou claríssimo em nossas pesquisas, o quanto, desde Roma com suas locatio, o pensamento evoluiu sempre na mesma trilha de se buscar uma proteção da pessoa enquanto centro da relação contratual. Mesmo, antes da boa-fé alcançar este patamar de objetividade, a própria teoria dos vícios de consentimento já denunciaria o prelúdio do surgimento de uma proteção jurídica calcada num preceito de eticidade.

32- Foi extremamente importante, demonstrar ao longo desta parte do trabalho como o princípio chegou a nossos dias, principalmente pelo pensamento alemão, inserindo como cláusula protetiva da relação uma série de valores superiores e congruentes com comportamentos desviantes estabilizados no contexto social ao longo de vários séculos de conquistas, logo, por seu caráter evolutivo, caminham no mesmo passo da evolução do sistema social diferenciado. Assim, pudemos observar que a estrutura formal há muito cultivada no Direito Civil passou a ser um conjunto de elementos primários e anteriores na formação da relação contratual, de sorte que a função dada ao contrato, se quebrada, abriria ferida insanável no contexto social, invalidando o contrato ainda que válido do ponto de vista meramente formal (sujeito, objeto e forma).

33- E vimos a aplicação da tópica também neste cenário a partir da realização de uma função hermenêutica realizada em razão da boa-fé, em que nossos Tribunais vão 
buscar aplicar o princípio a partir de uma violação positiva do contrato, afastando a concepção tradicionalista de que a consecução e satisfação do vínculo obrigacional se dá apenas pelo adimplemento da prestação pactuada. A boa-fé, por irradiar-se em todos os momentos contratuais, vai incidir como vetor a ser respeitado em cada fase e a quebra desses deveres éticos será investigada no caso concreto. 


\section{REFERÊNCIAS}

ACKERMAN, Bruce. Nós o povo soberano: fundamentos do direito constitucional. Tradução: Mauro Raposo de Mello; Coordenador e supervisor Luiz Moreira. Belo Horizonte: Del Rey, 2006.

AGostinho, Santo. A cidade de Deus (De civitate Dei). Int: Padre Riolando Azzi. Tradução: Oscar Paes Leme. São Paulo: EDAMERIS, s/d.

ALEXY, Robert. Conceito e validade do direito. Tradução: Gercélia Batista de Oliveira Mendes. São Paulo: Editora WMF Martins Fontes, 2009.

ALMEIDA, Gregório Assagra de. Direito material coletivo: superação da summa divisio direito público e direito privado por uma nova summa divisio constitucionalizada. Belo Horizonte: Del Rey, 2008.

AQUINO, São Tomás. Suma Teológica. Trad. Aimom-Marie Roguet et al. São Paulo: Loyola ,2001.

ARENDT, Hannah. A condição humana. Tradução: Roberto Raposo, revisão técnica: Adriano Correia. 11.ed. 2014.

Companhia das Letras, 2011.

Sobre a revolução. Tradução: Denise Bottman. São Paulo:

ARISTÓTELES. Metafísica. Tradução, textos adicionais e notas: Edson Bini. 2.ed. São Paulo: EDIPRO, 2012.

AVILA, Humberto. Teoria dos Princípios: da definição à aplicação dos princípios jurídicos. São Paulo: MALHEIROS EDITORES LTDA, 11ª ed, 2010.

AZEVEDO, Antonio Junqueira de. A boa-fé na formação dos contratos. In: Revista da Faculdade de Direito, Universidade de São Paulo. n.87. São Paulo, 1992, p.79-90.

BENJAMIN, Antônio Herman; MARQUES, Claudia Lima; BESSA, Leonardo Roscoe Bessa. Manual de Direito do Consumidor. 2.ed. São Paulo: Editora Revista dos Tribunais, 2009.

BOBBIO, Norberto. Dalla struttura alla funzione. Milano/IT: Edizioni di Comunità, 1984.

CAENEGEM, R.C. Van. Uma introdução histórica ao direito privado. Tradução: Carlos Eduardo Lima Machado, 2a .ed, São Paulo: Martins Fontes 1999.

CANARIS, Claus- Wilhelm. Pensamento sistemático e conceito de sistema na ciência do direito. Introdução e trad. De A. Menezes Cordeiro. Lisboa: Fundação Calouste Gulbenkian, 1996. 
CANOTILHO, Joaquim José Gomes; MENDES, Gilmar Ferreira; SARLET, Ingo Wolfang; STRECK, Lenio Luiz; LEONCY, Léo Ferreira. Comentários à Constituição do Brasil. São Paulo: Almedina, 2013.

CAVALCANTI, Themístocles Brandão; BRITO, Luiz Navarro de; BALEEIRO, Aliomar. Constituições Brasileiras. Volume VI. Constituição de 1967. 3.ed. Brasília: Senado Federal, Subsecretaria de Edições Técnicas, 2012.

COULANGES, Fustel. A cidade antiga. Tradução: Jean Melville, São Paulo: Martin Claret, 2007.

DELMAS-MARTY, Mireille. Por um direito comum. Tradução: Maria Ermantina de Almeida Prado Galvão. São Paulo: Martins Fontes, 2004.

DINIZ, Maria Helena. Curso de Direito Civil brasileiro, volume 3: teoria das obrigações contratuais e extracontratuais. 25.ed. Reformulada. São Paulo: SARAIVA, 2009.

. Curso de Direito Civil brasileiro, volume 4: Direito das coisas. 24.ed. Reformulada. São Paulo: SARAIVA, 2009.

DURKEIM, Emilie. A Divisão do trabalho social. $2^{\mathrm{a}}$ ed, Editorial Presença LTDA, tradução: Eduardo Freitas e Maria Inês Mansinho, Lisboa: s/d.

FACHIN, Luiz Edson. Direito Civil: sentidos, transformações e fim. Rio de Janeiro: Renovar, 2015.

FERRAJOLI, Luigi. Derechos y Garantias. La Ley Del Más Débil. Madrid/Es: Trotta, 2008.

FILARDI, Luiz Antônio. Curso de Direito Romano. 3.ed. São Paulo: Atlas, 1999.

GAGLIANO, Pablo Stolze; FILHO, Rodrigo Pamplona. Novo Curso de Direito Civil. Volume IV. Contratos: tomo 1; Teoria Geral. 3.ed. rev., atual. e ampl. São Paulo: SARAIVA, 2007.

GHERSI, Carlos Alberto. Obligaciones civiles y comerciales. 2.ed. actualizada y ampliada. Buenos Aires/Ar: ASTREA, 2005.

GAIO. Instituições. Direito Privado Romano. Lisboa/PT: Fundação Calouste Gulbenkian, 2010.

GARCIA, Juan Antonio Amado. Teorías de la tópica jurídica. Madri: Civitas, 1988.

GOMES, Orlando. Contratos. Rio de Janeiro: Forense, 2000.

GRIJALVA, Augustín. $O$ Estado Plurinacional e Intercultural na Constituição Equatoriana de 2008. In: Povos Indígenas: Constituições e reformas Políticas na américa Latina / [organizador Ricardo Verdum]. - Brasília: Instituto de Estudos socioeconômicos, 2009. 
HABERMAS, Jürgen. Sobre a constituição da Europa. Tradução: Denilson Luis Werle, Luiz Repa e Rúrion Melo. São Paulo: ed. UNESP, 2012.

Teoria do agir comunicativo, 2: sobre a crítica da razão funcionalista. Tradução: Flávio Beno Siebeneichler. São Paulo: Editora WMF Martins Fontes, 2012.

The concept of human dignity and the realistic utopia of human rights. Article first published online: 20 jul. 2010 / DOI: 10.1111/j.14679973.2010.01648.x / (C) 2010 the Author. Journal compilation (C) 2010 Metaphilosophy LLC and Blackwell Publishing Ltd / Metaphilosophy Volume 41, Issue 4 (tradução livre Menelick Carvalho Netto).

HART, H.L.A. O conceito de direito. São Paulo: WMF Martins Fontes, 2009.

HAZ, Joseph. O conceito de sistema Jurídico: uma introdução à teoria dos sistemas jurídicos. Trad. Maria Cecília Almeida. São Paulo: Editora WMF Martins Fontes, 2012.

HEGEL, Georg Wilhelm Friedrich. Fenomenologia do Espiríto. Parte I. Tradução: Paulo Meneses com colaboração de Karl-Helnz Efken. 2.ed. Petrópolis/RJ: VOZES, 1992.

HESSE, Konrad. Derecho constitucional y derecho privado. Trad. Ignácio Gutiérrez G. Madri: Civitas, 1995.

. A força normativa da Constituição. Tradução: Gilmar Ferreira Mendes. Porto Alegre: Sergio Antonio Fabris Editor, 1999.

Temas fundamentais do direito constitucional. Tradução:Carlos dos Santos Almeida, Gilmar Ferreira Mendes, Innocêncio Mártires Coelho. São Paulo: Saraiva, 2009.

HOBBES, Thomas. Leviatã ou matéria, forma e poder de um Estado Eclesiástico e Civil. (orig. 1651). Tradução: Rosina D’Angina. 1.ed. São Paulo: Martin Claret, 2014.

Juan Antonio Amado. Teorías de la tópica jurídica. Madri: Civitas, 1988.

KLAUS Lüderssen. Dialektik, Topik und KonKretes Ordnungsdenken in der Jurisprudenz. In: Festschrift für Richard Lange zum 70. Geburstag, de Gruyter, Berlim/Nova York 1976.

KANT, Immanuel. Crítica da Razão Pura. Tradução: Manuela Pinto dos Santos e Alexandre Fradique Morujão. Lisboa/Portugal: Fundação Calouste Gulbenkian, 5.ed., 2001.

Quintela Lisboa/PT: Edições 70, LDA.

KELSEN, Hans. Teoria Pura do Direito. São Paulo: Martins Fontes, 7ed., 2009 
LARENZ, Karl. Metodologia da ciência do Direito. Fundação Calouste Gulbenkian, 2.ed, 1989.

LEAL, Saul Tourinho. Direito à felicidade. Rio de Janeiro: ABDR, 2014.

LÔBO, Paulo Luiz Netto. Constitucionalização do Direito Civil. In: Revista de Informação Legislativa- Senado Fededral, n.141, janeiro/março, 1999.

LUHMANN, Niklas. Introdução à Teoria dos Sistemas. Aulas publicadas por Javier Torres Nafarrate. Tradução: Ana Cristina Arantes Nasser. 2.ed. Petrópolis/RJ: Vozes, 2010.

La sociedad de la sociedad. Ciudad de México: Universidad Iberoamericana/Herder ditorial, 2007.

MARTINS-COSTA, Judith. As cláusulas gerais no projeto do Código Civil brasileiro. In: Revista da Faculdade de Direito da UFRGS, vl.15. Porto Alegre: Síntese, 1998.

A boa-fé no Direito Brasileiro. São Paulo: RT, 2000.

A reconstrução do direito privado: reflexos dos princípios, diretrizes e direitos fundamentais constitucionais no direito privado. São Paulo: Editora RT, 2002.

MATURANA, Humberto R; VARELA, Francisco J. A árvore do conhecimento: as bases biológicas da compreensão humana. Tradução: Humberto Mariotti e Lia Diskin. São Paulo: Palas Athena, 2001.

MAXIMILIANO, Carlos. Hermenêutica e aplicação do Direito. Rio de Janeiro: Forense, 2003.

MENEZES, Olindo Herculano. Perfil da propriedade contemporânea (Destaque da propriedade fundiária). 2009. 517f. Tese (Doutorado em Direito). Departamento de Pósgraduação da Faculdade de Direito, Universidade de Brasília, Brasília/DF, 2009.

MONTESQUIEU, Charles de Secondat, Baron de. Do Espírito das Leis. Tradução: Roberto Leal Ferreira. São Paulo: Martin Claret, 2010.

NETTO, Carvalho. Menelick de. A hermenêutica constitucional e os desafios postos aos direitos fundamentais. Jurisdição constitucional $e$ os direitos fundamentais. Belo Horizonte: Del Rey, 2003.

NEVES, Marcelo. Entre Têmis e Leviatã: uma relação difícil: o Estado Democrático de Direito a partir e além de Luhmann e Habermas. São Paulo: Editora WMF Martins Fontes, $3^{\mathrm{a}}$ ed, 2012.

2009.

. Transconstitucionalismo. São Paulo: Editora WMF Martins Fontes, 
A constitucionalização simbólica. São Paulo: $3^{\mathrm{a}}$ ed.WMF Martins

Fontes, 2013.

PAIXÃO, Cristiano. Arqueologia de uma Distinção: o Público e o Privado na Experiência Histórica do Direito. In: O novo direito administrativo brasileiro, o Estado, as agências e o terceiro setor. Cláudia Fernanda de Oliveira Pereira (org). Belo Horizonte: Fórum, 2003.

PERLINGIERI, Pietro. O Direito Civil na legalidade Constitucional. Tradução: Maria Cristina de Cicco. Rio de Janeiro: Renovar, 2008.

Perfis do direito civil. Introdução ao direito Direito Civil Constitucional. Tradução: Maria Cristina Cicco. 3.ed. Rio de Janeiro: RENOVAR, 1997.

POLETTI, Ronaldo. Constituições Brasileiras. Volume III. Constituição de 1934. 3.ed. Brasília: Senado Federal, Subsecretaria de Edições Técnicas, 2012.

PLATÃO. A República (ou da justiça). Livro segundo, 370. Tradução, textos e notas: Edson Bini. Bauru/SP: EDIPRO, 2006.

RIZZARDO, Arnaldo. Contratos. Rio de Janeiro: Forense, 2006.

RIZZARDO, Arnaldo. Direito das Coisas. Rio de Janeiro: Forense, 2007.

ROESLER, Claudia Rosane. Theodor Viehweg e a ciência do Direito. Tópica, Discurso, Racionalidade. 2.ed. Belo Horizonte: Arraes Editores, 2013.

RODOTÀ, Stefano. Il diritto di avere diritti. Roma-Bari, Editori Laterza, 2012.

ROSENVALD, Nelson. A função social do contrato. In: Direito contratual: temas atuais. Coordenação: Giselda Maria Fernandes Novaes Hironaka e Flavio Tartuce. São Paulo: Método, 2007.

SANTOS, José Henrique. Trabalho e riqueza na fenomenologia do espírito de Hegel. São Paulo: Loyola, 1993.

SANTOS JUSTO, Antonio. Direito Privado Romano (Direitos Reais) III. Coimbra/PT: Coimbra Editora, Boletim da Faculdade de Direito da Universidade de Coimbra, 2014.

Direito Privado Romano (Direito das Obrigações) II. 4.ed. Coimbra/PT: Coimbra Editora, Boletim da Faculdade de Direito da Universidade de Coimbra, 2014.

SARLET, Ingo Wolfgang. A eficácia dos direitos fundamentais: uma teoria geral dos direitos fundamentais na perspectiva constitucional. 2.tir. 10.ed. ver. Atual. e ampl. Porto Alegre: Livraria do Advogado, 2009.

SCHREIBER, Anderson. A boa-fé objetiva e o adimplemento substancial. In: Direito Contratual: temais atuais. Coord: Giselda Maria Fernandes Novaes Hironaka e Flávio Tartuce. São Paulo: Método, 2007 
SILVA, Clovis do Couto e. A obrigação como processo. Rio de Janeiro: FGV, 2006.

TEPEDINO, Gustavo; SCHREIBER, Anderson. A Garantia da propriedade no Direito Brasileiro. In: Revista da Faculdade de Direito de Campos, Ano VI, n.6, julho/2005.

TEUBNER, Gunther. Direito, Sistema e Policontexturalidade. 1º. ed. Piracicaba: EDITORA UNIMEP, 2005.

Gulbenkian, 1994. O direito como sistema autopoiético. Lisboa/PT: Fundação Calouste

The Global Bukowina on the Emergence of a Transnational Legal Pluralism. In: IMPULSO, Piracicaba, v. 14, n. 33, p. 1-191, jan. /abr. 2003.

VARELA, laura Beck; LUDWIG, Marcos de Campos. Da propriedade às propriedades: função social e reconstrução de um Direito. In: MARTINS-COSTA, Judith. A reconstrução do direito privado: reflexos dos princípios, diretrizes e direitos fundamentais constitucionais no direito privado. São Paulo: Editora RT, 2002.

VENOSA, Silvio de Salvo. Direitos Reais. Vol. 5. 13.ed. São Paulo: Atlas, 2013.

ZANITELLI, Leandro. Tópica e pensamento sistemático: Convergência ou ruptura. In: COSTA, Judith Martins. A reconstrução do direito privado: reflexos dos princípios, diretrizes e direitos fundamentais constitucionais no direito privado. São Paulo: Editora RT, 2002.

WEBER, Max. Economia e sociedade: fundamentos da sociologia compreensiva. Tradução de Regis Barbosa e Karen Elsabe Barbosa; Revisão técnica de Gabriel Cohn, vol II. Brasília/DF: Editora Universidade de Brasília. São Paulo: Imprensa Oficial do Estado de São Paulo, 1999.

WOLKMER, Antonio Carlos. Pluralismo e crítica do Constitucionalismo na América Latina. In: anais do IX Simpósio de Direito Constitucional. Academia de Direito Constitucional, 2010.

\section{REFERÊNCIAS LEGISLATIVAS:}

ALEMANHA. Bürgerliches Gesetzbuch. Disponível em < https://www.gesetze-iminternet.de/bundesrecht/bgb/gesamt.pdf > Acesso em 20/10/2015.

BRASIL. Lei 10406 de 10 de janeiro de 2002. Institui o Código Civil. DOU de 11.1.2002.

BRASIL. Lei 13.146 de 6 de julho de 2015. Institui a Lei Brasileira de Inclusão da Pessoa com deficiência (Estatuto da Pessoa com deficiência). DOU de 07.07.2015.

BRASIL. Superior Tribunal de Justiça. Recurso Especial no 27.039-3/SP. Rel. Ministro Nilson Naves, Julgado em 8 de novembro de 1993. 
BRASIL. Superior Tribunal de Justiça. Recurso Especial no 1138517/MG. Rel. Ministro Humberto Martins, segunda turma, julgado em 18/08/2011, DJe 01/09/2011.

FRANÇA. Declaração dos Direitos do homem e do cidadão. Texto traduzido pelo Senado Francês. Disponível em < http://www.senat.fr/lng/pt/declaration_droits_homme.html> Acesso em 16/02/2016.

FRANÇA. Code Civil. 111.édition. Paris/Fr: Éditions DALLOZ, 2012.

ITALIA. Costituzione della Repubblica Italiana. Roma: Libreria del Senato, 2009. 